\begin{abstract}
UNIVERSIDADE DE SÃO PAULO
FACULDADE DE ECONOMIA, ADMINISTRAÇÃO E CONTABILIDADE DEPARTAMENTO DE ADMINISTRAÇÃO
\end{abstract}

DISSERTAÇÃO DE MESTRADO

EFEITOS DA DIVERSIFICAÇÃO NO VALOR DAS EMPRESAS DO MERCADO DE TELECOMUNICAÇÕES: TESTE DO MODELO DE BERGER E OFEK VAGNER ROBERTO ARAUJO DE ANDRADE ORIENTADOR: PROF. DR. RUBENS FAMÁ SÃO PAULO JANEIRO DE 2002 


\author{
UNIVERSIDADE DE SÃO PAULO \\ FACULDADE DE ECONOMIA, ADMINISTRAÇÃO E CONTABILIDADE \\ DEPARTAMENTO DE ADMINISTRAÇÃO
}

\title{
EFEITOS DA DIVERSIFICAÇÃO NO VALOR DAS EMPRESAS DO MERCADO DE TELECOMUNICAÇÕES: TESTE DO MODELO DE BERGER E OFEK
}

VAGNER ROBERTO ARAUJO DE ANDRADE

Dissertação apresentada ao Departamento de Administração da Faculdade de Economia, Administração e Contabilidade da Universidade de São Paulo como parte dos requisitos para obtenção do título de Mestre em Administração, sob orientação do Prof. Dr. Rubens Famá

SÃO PAULO

JANEIRO DE 2002 
Reitor da Universidade de São Paulo Prof. Dr. Adolpho José Melfi

Diretor da Faculdade de Economia, Administração e Contabilidade Prof. Dr. Eliseu Martins

Chefe do Departamento de Administração

Prof. Dr. Eduardo Pinheiro Gondin de Vasconcellos 
"Teu, Senhor, é o poder, a grandeza, a honra, a vitória e a majestade; porque teu é tudo quanto há nos céus e na terra; teu, Senhor, é o reino, e tu te exaltaste por chefe sobre todos. Riquezas e glória vêm de ti, tu dominas sobre tudo, na tua mão há força $\mathrm{e}$ poder; contigo está o engrandecer e a tudo dar forças. Agora, pois, ó nosso Deus, graças te damos e louvamos o teu glorioso nome."

Sagradas Escrituras, Livro de 1 Crônicas, capítulo 29, versos de 11 a 13 
A minha querida e amada esposa Samantha, incentivadora contumaz dos meus estudos, que participa comigo de todas as conquistas e mantém o seu fiel e agradável incentivo nos momentos de dúvidas e dificuldades. 
Embora o desenvolvimento da dissertação seja um trabalho individual, ele não é um trabalho solitário. Algumas pessoas foram importantes no decorrer desta atividade:

$\checkmark$ Deus, ao único que é digno de receber a honra e a glória, a força e o poder. Ao rei eterno imortal, invisível mas real, a Ele dedico o louvor.

$\checkmark$ Samantha, minha querida e adorável esposa, pela sua paciência e compreensão nos momentos que tive que abdicar do convívio pessoal para dedicar-me ao mestrado

$\checkmark$ Prof. Dr. Rubens Famá, pelo estímulo ao meu desenvolvimento acadêmico através das valorosas aulas de Teoria de Finanças e artigos que escrevemos em conjunto além da orientação no desenvolvimento desta Dissertação

$\checkmark$ Professores Doutores José Carlos Moreira e João Carlos Hopp que ofereceram valiosas contribuições quando participaram da banca examinadora do exame de qualificação

$\checkmark$ Ericsson Telecomunicações S.A., na pessoa do Sr. Marcos de Souza Santos, que desde o início permitiu que eu conciliasse a minha atividade profissional com a minha carreira acadêmica

$\checkmark$ Cláudio Cyrino Duarte de Souza, amigo mais que irmão de longa data, que sempre me apoiou, principalmente no princípio da minha vida acadêmica, ainda no curso de graduação 
Durante as décadas de 50 e 60, muitas empresas norte-americanas iniciaram um processo intenso de diversificação. Este processo atingiu seu ponto máximo com mais uma onda de fusões do final da década de 60 e que culminou com o surgimento de conglomerados corporativos gigantes. Nos últimos 15 anos, a tendência tem se revertido como mostra os recentes estudos de COMMENT e JARREL (1994), BERGER e OFEK (1995) e LIEBESKIND e OPLER (1993), que documentam o retorno à especialização. Este movimento em direção à especialização aparentemente resultou da visão de que diversificação de empresas não-correlacionadas diminui o valor da empresa.

Argumentos teóricos sugerem que a diversificação tem tanto efeito de aumentar o valor da empresa como de diminuir. Os benefícios potenciais de se operar diferentes linhas de negócio como se fossem uma única empresa incluem maior eficiência operacional, menor possibilidade de perder projetos com valor presente líquido positivo, maior capacidade de alavancagem financeira e menores impostos. Os custos potenciais da diversificação incluem o uso de recursos em projetos que diminuem o valor da empresa, subsídios entre unidades de negócios que permitem unidades com baixo desempenho se aproveitarem dos recursos gerados por unidades com alto desempenho e conflito de interesse entre os executivos das unidades de negócio e da corporação. Não há predições claras sobre o efeito global da diversificação no valor da empresa.

Foram utilizados dados de unidades de negócio para estimar o efeito da diversificação no valor das empresas no setor de telecomunicações da economia norte-americana. Comparou-se a soma das unidades de negócio diversificadas com valores imputados pelo modelo com os seus valores reais dentro das corporações a que pertencem. As empresas 
diversificadas tiveram seus valores em média, durante o período de 1990-99, entre 0,2\% e 6,4\% acima dos valores imputados pelo modelo. O trabalho está dividido da seguinte forma: o capítulo 1 apresenta o problema de pesquisa, mostrando sua origem e importância; o capítulo 2 revisa a fundamentação teórica e detalha alguns resultados de estudos anteriores sobre os efeitos da diversificação; capítulo 3 descreve a amostra utilizada e o modelo de pesquisa aplicado; o capítulo 4 mostra os efeitos da diversificação nas empresas do setor de telecomunicações do mercado norte-americano entre os anos de 1990 e 1999; o capítulo 5 apresenta as considerações finais com sugestões de novos estudos sobre este assunto. 
During the 1950s and '60s many US corporations undertook massive diversification programs. This process reached its climax with the merger wave of the late 1960s and the accompanying rise to prominence of huge conglomerate firms. In the last 15 years the trends has reversed, with studies by COMMENT and JARREL (1994), BERGER and OFEK (1995) and LIEBESK and OPLER (1993) documenting a return to specialization. This push toward focus apparently resulted from the view that unrelated diversification decreases firm value.

Theoretical arguments suggest that diversification has both valueenhancing and value-reducing effects. The potential benefits of operating different lines of business within one firm include greater operating efficiency, less incentive to forego positive net present value projects, greater debt capacity, and lower taxes. The potential costs of diversification include the use of increased discretionary resources to undertake value-decreasing investments, cross subsidies that allow poor segments to drain resources from better-performing segments, and misalignment of incentives between central and divisional managers. There is no clear prediction about the overall value effect of diversification.

In this study, it was used segment-level data to estimate the valuation effect of diversification on US Telecom companies. It was compared the sum of imputed stand-alone values of the segments of diversified companies to the actual values of those companies. It was documented that diversified firms have values that average, during $1990-99,0,3 \%$ to $6,4 \%$ above the sum of the imputed values of their segments.

Chapter 1 describes the main goal of this study and its genesis. Chapter 2 reviews the related literature and details the predicting resulting from prior theoretical work. Chapter 3 describes the sample and explains the empirical approach. Chapter 4 assesses the overall value effect of 
diversification using imputed segment values and a comparison of profitability between diversified and single-segment firms. Finally, Chapter 5 describes the final considerations about the diversification's effect on firm value. 
I. O PROBLEMA DE PESQUISA

I.1. INTRODUÇÃO 2

I.2. JUSTIFICATIVAS DA REALIZAÇÃO DA PESQUISA 6

I.2.1. FUSÕES E AQUISIÇÕES NO MERCADO LATINO AMERICANO 11

I.2.2. FUSÕES E AQUISIÇÕES NO MERCADO BRASILEIRO 12

I.3. DEFINIÇÃO DA SITUAÇÃO PROBLEMA 13

I.4. OBJETIVOS DE PESQUISA 15

I.5. HIPÓTESES 16

I.6. DEFINIÇÃO CONCEITUAL E OPERACIONAL 16

I.7. ORGANIZAÇÃO DO ESTUDO 17

II. FUNDAMENTAÇÃO TEÓRICA 22

II.1. ALOCAÇÃO DE RECURSOS E MOTIVOS DE INVESTIMENTOS 22

II.2. DIVERSIFICAÇÃO COMO REDUÇÃO DE RISCO 24

II.3. PROBLEMAS NA DIVERSIFICAÇÃO 26

II.4. DIVERSIFICAÇÃO EM EMPRESAS CORRELATAS E NÃO-CORRELATAS 27

II.5. DIVERSIFICAÇÃO EM EMPRESAS DE SERVIÇOS 29

II.6. DA DIVERSIFICAÇÃO À ESPECIALIZAÇÃO 32

II.7. O PROCESSO DE FUSÕES E AQUISIÇÕES COMO DIVERSIFICAÇÃO 36

II.7.1. TIPOS DE AQUISIÇÕES 38

II.7.2. A CONTROVÉRSIA ENTRE DESENVOLVIMENTO INTERNO E AQUISIÇÃO 39

II.7.3. A BUSCA PELO CONTROLE CORPORATIVO 40

II.7.4. ALIANÇA ESTRATÉGICA: ALTERNATIVA ÀS FUSÕES E AQUISIÇÕES 42

II.7.5. CORRENTES TEÓRICAS SOBRE FUSÕES E AQUISIÇÕES 43

II.8. EVOLUÇÃO DO SETOR DE TELECOMUNICAÇÕES EM DIREÇÃO ÀS FUSÕES E AQUISIÇÕES 44

II.9. MAXIMIZAÇÃO DA RIQUEZA COMO FUNÇÃO-OBJETIVO 52

II.10. MÉTODOS DE AVALIAÇÃO 54

II.11. MEDIDAS DE VALOR 56

II.11.1. FLUXO DE CAIXA 56

II.11.2. LUCRO ECONÔMICO E LUCRO CONTÁBIL 58

II.11.3. ECONOMIC VALUE ADDED E MARKET VALUE ADDED___ 60

II.11.4. MEDIDAS DE DESEMPENHO UTILIZADAS NA AVALIAÇÃO 62 
II.12. ANÁLISE DE VALOR E ENGENHARIA DE VALOR 66

II.13. TAXA DE DESCONTO E CUSTO DE CAPITAL 69

III. METODOLOGIA DE PESQUISA 73

III.1. METODOLOGIAS EXISTENTES ___ 73

III.1.1. COM RELAÇÃO À NATUREZA DA VARIÁVEL PESQUISADA___ 73

III.1.2. COM RELAÇÃO AO OBJETIVO E AO GRAU EM QUE O PROBLEMA DE PESQUISA ESTÁ CRISTALIZADO _ 75

III.1.3. PESQUISA EXPLORATÓRIA___ 75

III.1.4. PESQUISA CONCLUSIVA DESCRITIVA _ 77

III.1.5. PESQUISA CASUAL _ 78

III.2. METODOLOGIA DE PESQUISA ADOTADA___ 78

III.2.1. USO DOS MÚLTIPLOS PARA VERIFICAR A VARIAÇÃO DE VALOR ___ 82

III.2.1.1. VENDAS _ 82

III.2.1.2. ATIVOS

III.2.1.3. LAJIR - LUCRO ANTES DOS JUROS E IMPOSTO DE RENDA ___ 83

III.3. TAMANHO DA AMOSTRA__ 83

III.4. ESTRATÉGIA DE COLETA DOS DADOS _ 84

III.5. TRATAMENTO E ANÁLISE DOS DADOS _ 87

III.6. INSTRUMENTOS DE MEDIDA __ 88

III.7. LIMITAÇÕES DO MÉTODO _ 88

IV. A PESQUISA

IV.1. IDENTIFICAÇÃO DA AMOSTRA _ 90

IV.1.1. PRINCIPAIS UEN _ 92

IV.1.2. EXCLUSÃO DOS DADOS _ _ 95

IV.1.2.1. FATURAMENTO _ 96

IV.1.2.2. PROBLEMAS DE VALIDAÇÃO __ 96

IV.1.2.3. LAJIR NEGATIVO _ 96

IV.1.2.4. EMPRESAS COM SETOR FINANCEIRO__ 97

IV.1.2.5. VALORES EXTREMOS __ 97

IV.1.3. QUANTIDADE DE EMPRESAS __ 98

IV.2. CARACTERÍSTICAS DA AMOSTRA DO PONTO DE VISTA DOS SEGMENTOS __ 101

IV.2.1. VENDAS 103

IV.2.2. ATIVOS 106

IV.2.3. LAJIR_ 109 
IV.3. CARACTERÍSTICAS DA AMOSTRA DO PONTO DE VISTO DA QUANTIDADE DE UEN 112

IV.3.1. VENDAS 112

IV.3.2. ATIVOS 114

IV.3.3. LAJIR 116

IV.4. TESTES DE HIPÓTESES 119

IV.4.1. NÚMERO MÉDIO DE UEN 120

IV.4.2. CARACTERIZAÇÃO DO SUBGRUPO DE DIVERSIFICAÇÃO 123

IV.4.3. VALOR MÉDIO DOS MÚLTIPLOS ANO A ANO 125

IV.5. APLICAÇÃO DOS MÚLTIPLOS 127

IV.5.1. VENDAS 129

IV.5.2. ATIVOS 130

IV.5.3. LAJIR 130

IV.5.4. COMPARAÇÃO ENTRE OS MÚLTIPLOS 131

IV.5.5. VERIFICAÇÃO DA TEORIA 132

\section{CONSIDERAÇÕES FINAIS}

V.1. SUGESTÕES PARA ESTUDOS FUTUROS E LIMITAÇÕES 142

\section{TABELAS}

TABELA1: AQUISIÇÕES DE EMPRESAS DE COMUNICAÇÃO DE DADOS 6

TABELA 2: FUSÕES E AQUISIÇÕES POR SETORES NO BRASIL 8

TABELA 3: AS 10 MAIORES TRANSAÇÕES GLOBAIS EM 2000 DE FUSÕES E AQUISIÇÕES 9 TABELA 4: OS 10 MAIORES COMPRADORES E VENDEDORES GLOBAIS EM 2000 TABELA 5 - PRINCIPAIS MUDANÇAS NO COMPLEXO ELETRÔNICO ASSOCIADAS AO NOVO PARADIGMA TECNO-ECONÔMICO DO FINAL DOS ANOS 40 AOS ANOS 90 TABELA 6 - CARACTERÍSTICAS DA PESQUISA QUALITATIVA E QUANTITATIVA TABELA 7 - CLASSIFICAÇÃO SIC TABELA 8 - SUBDIVISÃO DO GRUPO D - MANUFACTURING 85 TABELA 9 - SUBDIVISÃO DA CATEGORIA 36 - ELETRONIC 87 TABELA 10 - AGRUPAMENTO POR UEN BASEADO EM VENDAS 94 TABELA 11 - NÚMERO DE EMPRESAS ELIMINADAS DA AMOSTRA PRELIMINAR 98 TABELA 12 - AMOSTRA FINAL POR QUANTIDADE DE UEN E SEGMENTOS 100 TABELA 13 - ESTATÍSTICA DESCRITIVA DA AMOSTRA DE EMPRESAS 102 TABELA 14- ESTATÍSTICA DESCRITIVA DA AMOSTRA DE UEN 103 TABELA 15 - MÉDIA, MEDIANA, DESVIO-PADRÃO DAS VENDAS POR SEGMENTO 104 TABELA 16 - MÉDIA, MEDIANA, DESVIO-PADRÃO DOS ATIVOS POR SEGMENTO 107 TABELA 17 - MÉDIA, MEDIANA, DESVIO-PADRÃO DO LAJIR POR SEGMENTO 110 TABELA 18 - MÉDIA, MEDIANA E DESVIO-PADRÃO DE VENDAS POR QUANTIDADE DE UEN113 TABELA 19 - MÉDIA, MEDIANA E DESVIO-PADRÃO DE ATIVOS POR QUANTIDADE DE UEN 115 
TABELA 20- MÉDIA, MEDIANA E DESVIO-PADRÃO DO LAJIR POR QUANTIDADE DE UEN 117

TABELA 21 - MÉDIA, MEDIANA E DESVIO-PADRÃO DO QUANTIDADE DE UEN

TABELA 22 - EVOLUÇÃO PERCENTUAL DOS SUBGRUPOS SIC DENTRO DA AMOSTRA DE 476

EMPRESAS

TABELA 23 - EVOLUÇÃO EM VALORES ABSOLUTOS DOS SUBGRUPOS SIC DENTRO DA AMOSTRA DE 476 EMPRESAS

TABELA 24 - VALOR IMPUTADO - MÚLTIPLO VENDAS

TABELA 25 - VALOR IMPUTADO - MÚLTIPLO ATIVOS

TABELA 26 - VALOR IMPUTADO - MÚLTIPLO LAJIR

FIGURAS

FIGURA 1- MODELAGEM DO BANCO DE DADOS

\section{GRÁFICOS}

GRÁFICO 1 - FUSÕES E AQUISIÇÕES NA AMÉRICA LATINA

GRÁFICO 2- QUANTIDADE DE FUSÕES E AQUISIÇÕES NO BRASIL

GRÁFICO 3 - EVOLUÇÃO DAS VENDAS MÉDIAS POR SEGMENTO

GRÁFICO 4 - EVOLUÇÃO DOS ATIVOS MÉDIOS POR SEGMENTO

GRÁFICO 5 - EVOLUÇÃO DO LAJIR MÉDIO POR SEGMENTO

GRÁFICO 6 - EVOLUÇÃO DAS VENDAS POR QUANTIDADE DE UEN

GRÁFICO 7 - EVOLUÇÃO DOS ATIVOS POR QUANTIDADE DE UEN

GRÁFICO 8 - EVOLUÇÃO DO LAJIR POR QUANTIDADE DE UEN 
Capítulo I:

O PROBLEMA DE PESQUISA 


\section{O PROBLEMA DE PESQUISA}

\section{I.1. INTRODUÇÃO}

Até o final da década de 80 , havia relativamente poucos competidores na indústria de telecomunicações comparados ao número de operadoras de telefonia, e seus papéis eram claramente definidos. Os fabricantes de equipamentos vendiam seus produtos às grandes operadoras de telefonia monopolísticas ou oligopolísticas com os quais tinham relações longas e bem estabelecidas. Na última década do século $X X$, os EUA e os países europeus lideraram a abertura deste mercado através da privatização das empresas estatais e de novas concessões de operação para outras empresas com a finalidade de estimular a competição.

A privatização das operadoras de telecomunicações no Brasil também trouxe este ambiente de competição para um mercado que até então era totalmente monopolizado pelo Estado. Ele foi iniciado pelo leilão de concessões da banda B da telefonia celular, em janeiro de 1997, que rendeu aos cofres públicos US $\$ 7,5$ bilhões. O segundo passo foi a privatização do sistema Telebrás que foi dividido em 12 holdings: 3 de telefonia fixa, 8 de telefonia celular e 1 de longa distância. Esta segunda etapa foi concluída em julho de 1998, rendendo aos cofres públicos US\$ 18,5 bilhões, representando um prêmio de 63,7\% acima do preço mínimo. As grandes operadoras européias e norte-americanas de telefonia fixa e móvel emergentes da desregulamentação do mercado se mostraram presentes no processo de privatização, não só pelo interesse no mercado local, mas também com a finalidade de se firmarem no cenário global. Para tanto, grandes alianças entre as operadoras têm se formado através do processo de fusões e aquisições conduzindo à consolidação do mercado. 
Segundo estudos da Ericsson Telecomunicações, uma das maiores fornecedoras mundiais de infra-estrutura de telefonia fixa e móvel, nos próximos 5 a 10 anos, estima-se que entre 10 e 15 operadores dominarão o mercado mundial juntamente com 100 operadores regionais. Esta tendência conduzirá a uma necessidade de criação de padrões globais e servirá como base para o desenvolvimento de novos produtos.

Esse processo de consolidação das operadoras tem desencadeado também uma onda de fusões e aquisições nas empresas fornecedoras de equipamentos de telecomunicações. Não basta estar presente localmente onde o cliente se encontra; mas também oferecer soluções completas de telecomunicações. As grandes operadoras estão restringindo o número de fornecedores e, para isso, privilegiam aqueles que podem atendê-las através de um portfolio variado. Muitas empresas fornecedoras das operadoras telefônicas têm buscado esse aumento no seu portfolio de produtos e serviços através da fusão e aquisição de outras empresas que venham complementar estas atividades. Está se formando o "novo mercado de telecomunicações" que é a fusão das atividades de telecomunicação com as atividades da indústria de informática.

A tecnologia está avançando através do aumento da digitalização e da Internet. O desenvolvimento desta última e das Intranets é uma força que impulsiona a convergência dos serviços e dos produtos.

É possível que as informações via rádio, Internet, TV aberta e a cabo venham a chegar às casas por meio de um telecomputador, que terá também as funções de videocassete, telefone, ou melhor, videofone, além, é claro, do microcomputador para realizar trabalhos domésticos e profissionais. Esta mudança faz parte do que vem sendo chamado de convergência tecnológica dos meios de comunicação. 
Esse avanço tecnológico foi previsto por DIZARD (2000). O autor afirma que haverá empresas fornecedoras de informação, nos moldes das companhias de luz ou água, ou seja, o consumidor pagará uma taxa mensal para ter acesso ao produto, no caso, informação.

As empresas da indústria de programas para computadores e de comunicações de dados, tais como as norte-americanas Microsoft e Cisco respectivamente, estão penetrando em domínios tradicionais da indústria de telecomunicações produzindo mudanças neste setor da economia.

Estima-se para o ano 2001 que o tráfego de dados em redes de acesso superará o tráfego de voz sobre as atuais redes de telecomunicações, destacando-se a importância da Internet. Para tanto, as operadoras de telefonia terão de desenvolver um novo modelo de negócio porque nele o serviço de voz, hoje seu principal ponto de venda, não passará de uma commodity.

No mundo das operadoras, a telefonia IP (de "protocolo de Internet", na sigla em inglês), que permitirá ligações locais para qualquer parte do mundo, promete roubar tráfego da telefonia convencional. Segundo estudos do instituto de pesquisa norte-americano Pyramid Research, o aumento da competição, a guerra de preços e as novas tecnologias vão provocar a morte do mercado de longa distância.

Em 2003, a telefonia IP deverá responder por algo em torno de $23 \%$ de tráfego de longa distancia e $29 \%$ da telefonia internacional conforme prevê o International Data Corporation (IDC), um instituto de pesquisa da área de telecomunicações.

As operadoras de telecomunicações já estão investindo na transferência do seu tráfego para a Internet. Comparativamente, a transferência da tecnologia analógica para digital levou cerca de 15 anos e espera-se 
que a transferência do tráfego da telefonia fixa para a Internet ocorra na metade desse tempo.

As principais operadoras brasileiras estão refletindo um fenômeno em outros países relacionados à evolução da tecnologia. A comutação de circuitos (muito utilizada pelas redes de telefonia convencionais) será substituída pela de pacotes, que segmenta dados de modo a garantir sua melhor distribuição pela banda de transmissão e é apontada como solução para suportar o crescimento do tráfego de dados em virtude da Internet.

Economias substanciais poderão ser realizadas quando todas as informações forem transmitidas através da mesma rede, lideradas pelos dados, seguidos pela voz e, finalmente, pelo vídeo.

Uma estratégia das empresas de telecomunicações para obterem o domínio da tecnologia no mercado de comunicação de dados tem sido a aquisição de empresas que complementem as habilidades já existentes assim como em áreas críticas de produto ou de componentes. Isto significa concentrar em companhias pequenas e de tamanho médio com tecnologias de ponta. A Cisco é uma concorrente poderosa num mercado altamente crescente para transmissão de dados. Inicialmente, a Cisco focalizou-se no segmento corporativo. Com a explosão da Internet, a empresa começou a aumentar seu alcance, concentrando-se principalmente nas operadoras.

Esse desejo de atender aos clientes e não ceder espaço aos novos concorrentes está conduzindo empresas tradicionais de telecomunicações tais como a Ericsson, Lucent, Nortel e Alcatel à diversificação do seu portfolio através de decisões estratégicas que poderão refletir negativamente no valor da empresa e, conseqüentemente, na riqueza do acionista. A tabela a seguir mostra 
exemplos de empresas de comunicações de dados compradas pelas grandes fornecedoras do mercado de telecomunicações.

\begin{tabular}{|c|c|c|c|c|}
\hline COMPRADOR & ERICSSON & LUCENT & NORTEL & ALCATEL \\
\hline \multirow{6}{*}{$\begin{array}{c}\text { EMPRESAS DE } \\
\text { COMUNICAÇÕE } \\
\text { S DE DADOS } \\
\text { COMPRADAS }\end{array}$} & Torrent & $\begin{array}{l}\text { Ascend/ } \\
\text { Cascade }\end{array}$ & $\begin{array}{c}\text { Bay } \\
\text { Networks }\end{array}$ & Newbridge \\
\hline & Touchwave & Yurie Systems & Cambrian & \\
\hline & ACC & Kenan Systems & & \\
\hline & Juniper & & & \\
\hline & Mariposa & & & \\
\hline & GDC & & & \\
\hline
\end{tabular}

TABELA1: AQUISIÇÕES DE EMPRESAS DE COMUNICAÇÃO DE DADOS

A crescente diversificação das empresas americanas nas décadas de 50 e 60 começou a ser revertida nos anos 80 e permaneceu até a metade da década de 90. COMMENT e JARREL (1995) e LIEBESKIND e OPLER (1993) realizaram estudos que demonstram retorno à especialização. BERGER e OFEK (1995) acrescentaram aos estudos anteriores o efeito da diversificação no valor da empresa, demonstrando uma perda de valor entre 13\% e 15\% no período de 1986 e 1991.

\section{I.2. JUSTIFICATIVAS DA REALIZAÇÃO DA PESQUISA}

No ano de 2000, as transações de fusões e aquisições no mercado norte-americano atingiram o maior volume histórico de US\$1,83 trilhões. Este valor é maior do que o apresentado em 1998, onde foram realizadas operações no valor de US\$1,63 trilhões e acima do ano de 1999, que representou US\$1,57 trilhões. Estes valores apresentados também indicaram a continuação de uma tendência nas fusões e aquisições: o crescimento da participação de empresas estrangeiras. 
Mais de US\$ 356 bilhões, o que representa em torno de $20 \%$, dos anúncios ocorridos nos Estados Unidos tiveram empresas estrangeiras como compradoras. Em 1999, este número foi de US\$ 307 bilhões e em 1998, US\$ 256 bilhões. As empresas européias foram as mais participantes neste setor, destacando-se a Deutsche Telekom com a oferta de US\$54,7 bilhões pela Voice Stream Wireless, a Unilever plc ofertando US\$23,7 bilhões pela Bestfoods e o banco de investimentos suíço UBS oferecendo US\$ 15,5 bilhões pela aquisição da Painel Webber Group. Contudo, o maior anúncio realizado em 2000 foi a oferta da America OnLine de US\$ 182 bilhões para aquisição da Time Warner. Setorialmente, as indústrias de telecomunicações e de correios foram as mais ativas no mercado de fusões e aquisições globais em 1999, respondendo por 20\% do total (US\$ 159 bilhões), seguidas pela indústria química (US\$ 93 bilhões), extração de óleo mineral e gás natural (US\$ 75 bilhões), instituições financeiras (US\$ 59 bilhões) e energia (US\$ 42 bilhões). A indústria de telecomunicações e de correios já vem liderando esta operação nos últimos dez anos. A maior operação realizada, em 1999, foi a compra da operadora de telecomunicações norte-americana Airtouch Communications Inc pela britânica Vodafone Group plc, atingindo US\$ 69,3 bilhões. A ultrapassagem da marca dos US\$ 100 bilhões já era prevista para o ano de 2000 e, efetivamente ocorreu com a compra da Time Warner pela American Online, ambas norte-americanas, por US\$150 bilhões. Esta operação também se encontra no contexto da convergência tecnológica.

De acordo com o levantamento feito pela KPMG, $21 \%$ das transações realizadas no 10. trimestre de 2000 envolveram empresas de tecnologia da informação. Os dados consolidam uma inversão significativa, iniciada em 2000, no ranking das fusões e aquisições. Até 1998, o setor de 
alimentos, fumo e bebidas lideravam a lista. Em 1999, telecomunicações assumiu o primeiro lugar, seguido por tecnologia da informação.

\begin{tabular}{|cc|}
\hline SETORES & $\begin{array}{c}\text { NEGOCI } \\
\text { AÇÕES }\end{array}$ \\
\hline Tecnologia da Informação & 14 \\
\hline Alimentos, Bebidas e Fumo & 8 \\
\hline Telecomunicações & 5 \\
\hline Energia & 5 \\
\hline Finanças & 4 \\
\hline Fonte: Relatório Fusões e Aquisições KPMG, 10. Trimestre de 2000
\end{tabular}

TABELA 2: FUSÕES E AQUISIÇÕES POR SETORES NO BRASIL

\section{$1^{\text {O. }}$ TRIMESTRE DE 2000}

Os anúncios de transações em todo mundo para o ano de 2000 excederam US\$ 3,49 trilhões compreendendo mais de 36.700 transações com destaque para 0 setor de telecomunicações, participando com US\$ 483 bilhões. Se considerados os anúncios de transações iniciados em 2000 mas não concluídas dentro do mesmo ano, este valor sobe para US\$ 657 bilhões.

A começar pelos valores envolvidos nas operações, justifica-se o estudo que se pretende realizar. O surgimento de uma nova economia representada pela norte-americana no período de 1994 a 2000, onde 0 modelo de rápido crescimento, baixo desemprego e baixa taxa de inflação estava sendo rompido e uma nova indústria oriunda da convergência da indústria de telecomunicações, computadores e mídia, são assuntos atuais e ainda pouco explorados no meio acadêmico.

A tabela a seguir apresenta as maiores transações de fusões e aquisições globais realizadas no ano de 2000, indicando a data do anúncio da fusão ou aquisição, a empresa objeto da compra e a que 
setor econômico pertence, seguidos pela empresa compradora e o valor total da operação. Das 10 maiores operações, 4 envolvem empresas do setor de telecomunicações e 3 envolvem empresa do setor de entretenimento.

\begin{tabular}{|c|c|c|c|c|}
\hline ANÚNCIO & EMPRESA ALVO & $\begin{array}{l}\text { SETOR DE } \\
\text { ATIVIDADE }\end{array}$ & COMPRADOR & $\begin{array}{c}\text { VALOR } \\
\text { OPERAÇÃO } \\
\text { US\$ MILHÕES }\end{array}$ \\
\hline $10 / 01 / 00$ & Time Warner & $\begin{array}{l}\text { Entretenimen- } \\
\text { to }\end{array}$ & $\begin{array}{l}\text { American } \\
\text { Online Inc }\end{array}$ & 181.568 \\
\hline $17 / 01 / 00$ & $\begin{array}{l}\text { SmithKline } \\
\text { Beechman } \\
\text { plc }\end{array}$ & Farmacêutico & $\begin{array}{l}\text { Glaxo } \\
\text { Welcome plc }\end{array}$ & 77.255 \\
\hline $26 / 01 / 00$ & $\begin{array}{l}\text { Nortel } \\
\text { Networks }\end{array}$ & $\begin{array}{l}\text { Telecomunica } \\
\text { ções }\end{array}$ & Acionistas & 61.658 \\
\hline $24 / 07 / 00$ & $\begin{array}{l}\text { Voice Stream } \\
\text { Wireless Corp }\end{array}$ & $\begin{array}{l}\text { Telecomunica } \\
\text { ções }\end{array}$ & $\begin{array}{l}\text { Deutsche } \\
\text { Telkom }\end{array}$ & 54.750 \\
\hline $23 / 10 / 00$ & $\begin{array}{l}\text { Honeywell } \\
\text { Internation } \\
\text { Inc }\end{array}$ & Aviação & $\begin{array}{l}\text { General } \\
\text { Electric Co }\end{array}$ & 50.133 \\
\hline $24 / 10 / 00$ & $\begin{array}{l}\text { AT\&T } \\
\text { Wireless }\end{array}$ & $\begin{array}{l}\text { Telecomunica } \\
\text { ções }\end{array}$ & Acionistas & 46.291 \\
\hline $30 / 05 / 00$ & Orange plc & $\begin{array}{l}\text { Telecomunica } \\
\text { ções }\end{array}$ & $\begin{array}{l}\text { France } \\
\text { Telecom SA }\end{array}$ & 45.967 \\
\hline $15 / 11 / 00$ & $\begin{array}{l}\text { Liberty Media } \\
\text { Group }\end{array}$ & $\begin{array}{l}\text { Entretenimen- } \\
\text { to }\end{array}$ & Acionistas & 44.751 \\
\hline $16 / 10 / 00$ & Texaco Inc & $\begin{array}{l}\text { Exploração } \\
\text { petróleo }\end{array}$ & $\begin{array}{l}\text { Chevron } \\
\text { Corp }\end{array}$ & 43.318 \\
\hline $20 / 06 / 00$ & Seagram Ltd & $\begin{array}{l}\text { Entretenimen- } \\
\text { to }\end{array}$ & Vivendi SA & 42.782 \\
\hline
\end{tabular}

Fonte: Site da Thomas Financial Securities Data

TABELA 3: AS 10 MAIORES TRANSAÇÕES GLOBAIS EM 2000 DE FUSÕES E AQUISIÇÕES

De acordo com a KPMG, as empresas européias investiram US\$320 bilhões nas operações de fusões e aquisições com destino nos Estados Unidos, enquanto que o inverso representou US\$ 88 bilhões. O Reino Unido e a França foram os dois países com maiores valores envolvidos: US\$ 96 bilhões e 43 bilhões, respectivamente. Segundo o mesmo 
relatório, estes números indicam o desejo das corporações européias em investir além de suas fronteiras parcialmente como um reconhecimento de que para ser um participante global, as empresas necessitam capturar posições no mercado norte-americano.

A seguir, a tabela com os 10 maiores países compradores e vendedores em 2000 expressos em bilhões de dólares:

\begin{tabular}{clclc}
\hline $\begin{array}{c}\text { Classifi } \\
\text { cação }\end{array}$ & Comprador & $\begin{array}{c}\text { Valor US\$ } \\
\text { bilhões }\end{array}$ & Vendedor & $\begin{array}{c}\text { Valor US\$ } \\
\text { bilhões }\end{array}$ \\
\hline 1 & REINO UNIDO & 337.931 & ALEMANHA & 243.590 \\
\hline 2 & FRANÇA & 137.931 & EUA & 233.974 \\
\hline 3 & EUA & 134.483 & REINO UNIDO & 198.718 \\
\hline 4 & ALEMANHA & 62.069 & CANADÁ & 128.205 \\
\hline 5 & HOLANDA & 55.172 & FRANÇA & 48.077 \\
\hline 6 & SUIÇA & 51.724 & CHINA & 44.872 \\
\hline 7 & ESPANHA & 41.379 & HOLANDA & 38.462 \\
\hline 8 & HONG KONG & 37.931 & ESPANHA & 25.641 \\
\hline 9 & CANADÁ & 27.586 & SUIÇA & 22.436 \\
\hline 10 & JAPÃO & 20.690 & BRASIL & 19.231 \\
\hline
\end{tabular}

Fonte: Computasoft Research/ Commscan

TABELA 4: OS 10 MAIORES COMPRADORES E VENDEDORES GLOBAIS EM 2000

O termo nova economia surgiu para definir um comportamento do sistema econômico dos Estados Unidos diferente do tradicional. Os investimentos em novas tecnologias e informática garantiram uma forte expansão da produtividade. As empresas conseguiram produzir mais, com menor custo, menos mão de obra e maior margem de ganho. Esse movimento permitiu que a inflação se mantivesse sob controle mesmo diante de problemas como a alta dos preços do petróleo. A economia norte-americana apresentou um período de crescimento contínuo na 
última década. Durante este cenário, o receio era que em algum momento essa nova economia não conseguisse mais suportar as pressões inflacionarias, inclusive porque a expansão da atividade foi tão grande que mesmo com o forte aumento da produtividade houve uma oferta enorme de emprego. E o mercado de trabalho aquecido, pressiona o consumo, o que também poderia ter reflexos sobre a inflação. Diante deste contexto, o Banco Central Americano (Federal Reserve) ajustava os juros, elevando as taxas, para tentar esfriar um pouco o excessivo aquecimento econômico. Atualmente, este cenário está modificado e os Estados Unidos estão no início de uma recessão, onde a taxa de juros já baixou 10 vezes em 2001.

\section{I.2.1. FUSÕES E AQUISIÇÕES NO MERCADO LATINO AMERICANO}

O processo de fusões e aquisições na América Latina tem movimentado grandes quantias. Os países desta região têm apresentado elevados valores devido à privatização das empresas estatais.

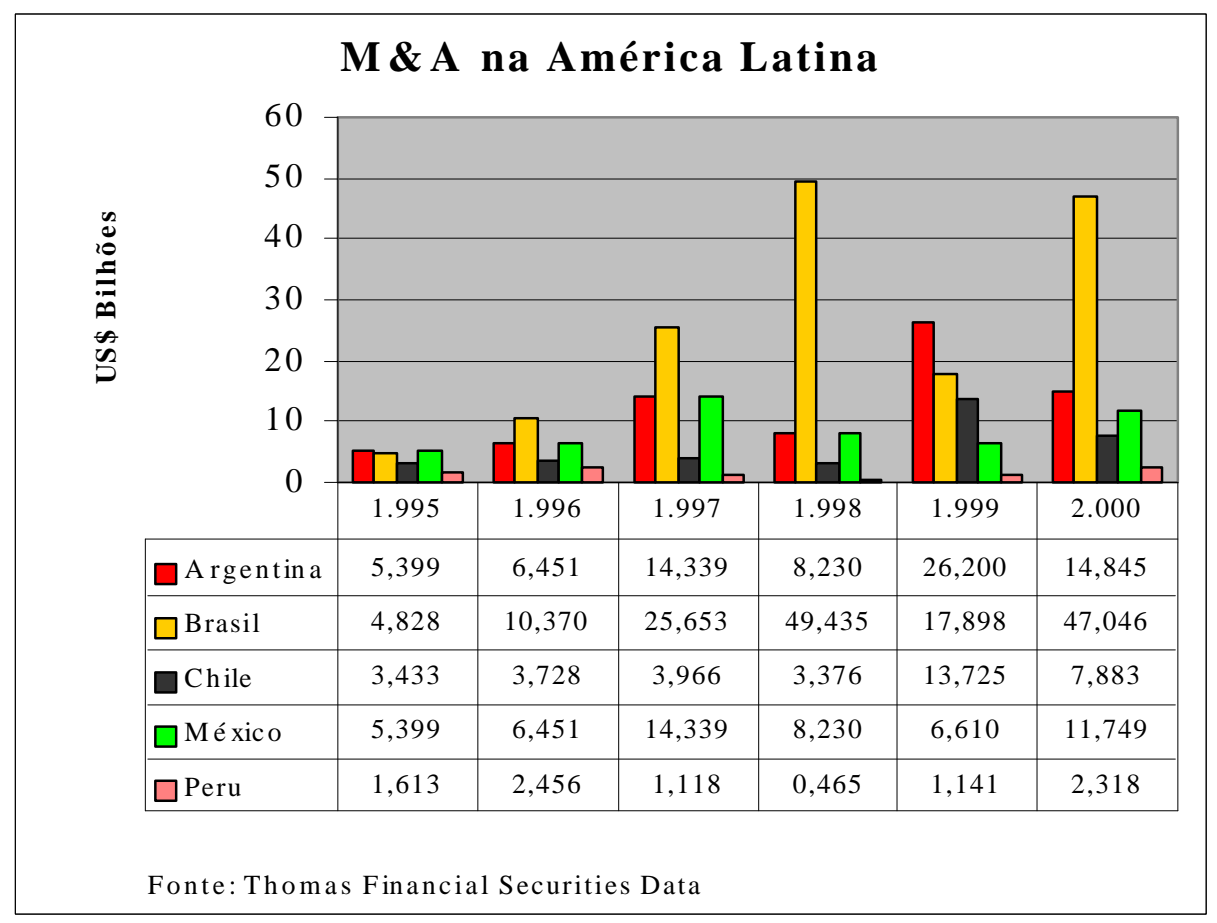

GRÁFICO 1 - FUSÕES E AQUISIÇÕES NA AMÉRICA LATINA 
Na América Latina, o Brasil ficou em segundo lugar em 1999, atrás apenas da Argentina, onde as fusões e aquisições de empresas movimentaram US\$26,2 bilhões sendo que duas (YPF e Repsol) representaram US\$ 19 bilhões do total das operações. Porém, recuperou a primeira posição em 2000 com transações totais de aproximadamente US\$ 47 bilhões.

\section{I.2.2. FUSÕES E AQUISIÇÕES NO MERCADO BRASILEIRO}

O cenário de fusões e aquisições no mercado brasileiro é otimista pois o início da colheita dos frutos da desvalorização cambial do início de 1999 está previsto para os próximos dois anos, dado que os ativos em reais estão mais baratos e atraentes devido à estabilidade econômica. Além disto, há a procura, por parte das empresas brasileiras, de capital para formar empresas com maior escala e oportunidades. No Brasil, as fusões e aquisições movimentaram $R$ \$17,898 bilhões em 1999 segundo o levantamento feito pela Thomson Financial Securities Data (TFSD), uma empresa provedora de dados financeiros e pesquisa, representando um resultado bem inferior aos quase US\$ 50 bilhões atingidos em 1998 neste tipo de operação. Apenas a privatização do sistema Telebrás e outras empresas estatais responderam por US\$27 bilhões contra US\$ 3 bilhões em 1999. 


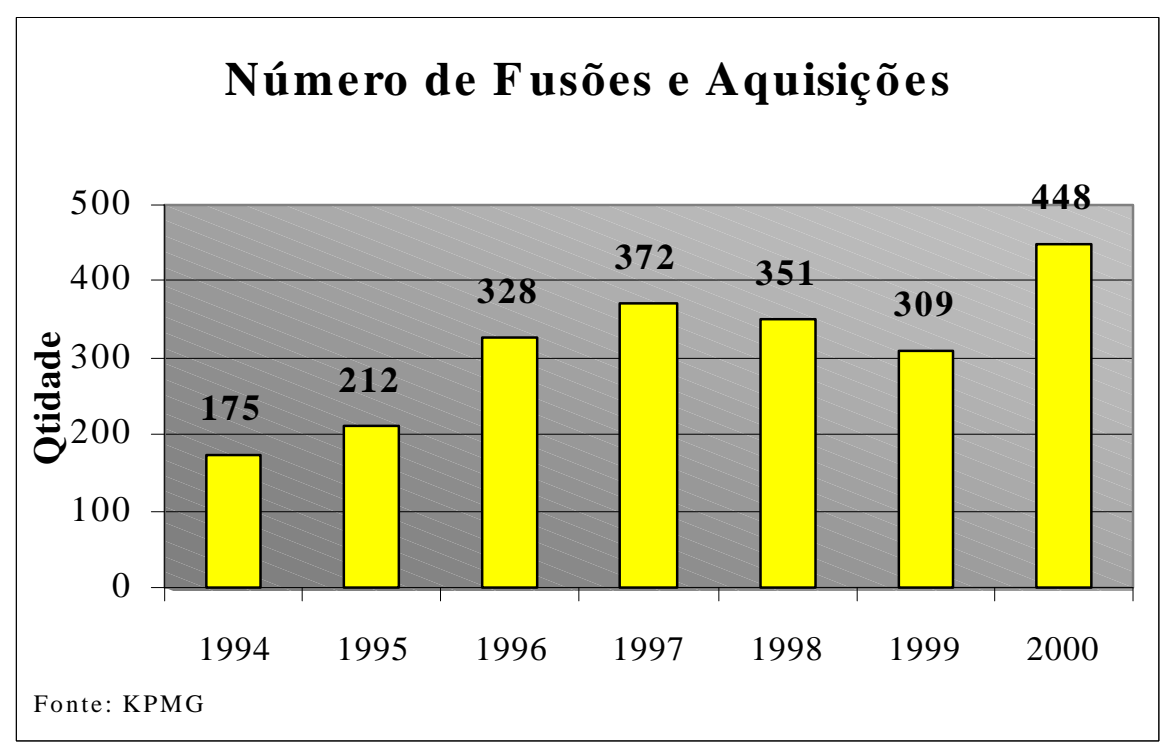

GRÁFICO 2- QUANTIDADE DE FUSÕES E AQUISIÇÕES NO BRASIL

Como se pode notar no gráfico 2, a quantidade de fusões e aquisições no Brasil tem se mantido elevada, demonstrando que o ano de 2000 teve a maior quantidade de operações dos últimos anos, muito embora não tenha sido o maior em volume financeiro.

\section{I.3. DEFINIÇÃO DA SITUAÇÃO PROBLEMA}

A existência e fonte de oportunidades potenciais para o crescimento rentável da empresa através de fusões e aquisições foram motivos de discussões e estudos cuidadosos na literatura financeira e econômica na década de 70. Apesar de todo este esforço para se buscar respostas, em 1968, no pico do movimento de fusões do pós-guerra, SEGALL (1968) afirmou:

"Não há uma única hipótese que seja simultaneamente plausível e geral e que prometa explicar o atual movimento de fusões. Assim sendo, é correto dizer que não se sabe nada conhecido sobre fusões; não há quaisquer generalizações úteis".

Dentre os vários estudos analisados e explorados durante 0 desenvolvido desta dissertação tais como MODIGLIANI e MILLER (1958 
e 1963), COMMENT e JARREL (1995), BERGER e OFEK (1995), BREALEY e MYERS (1997), que questionam o aumento de valor das empresas envolvidas na diversificação, surge a dúvida se as empresas de telecomunicações não estão adotando uma estratégia que posteriormente será renunciada em favor da especialização, ou seja, um caminho inverso a convergência das indústrias. Pode-se especular se uma alternativa para as grandes fusões e aquisições não seria a parceria, ou seja, dois fornecedores se unem para fornecerem uma solução ao cliente mas mantêm suas identidades como é o caso das joint-ventures. Atualmente, as fusões e aquisições estão ocorrendo para concentrar todas as soluções debaixo de um mesmo comando. Mas será isto realmente necessário? Caso se comprove que a empresa perde valor com o processo de fusão ou aquisição, talvez fosse realmente interessante estudar a possibilidade de parceria com administrações separadas. Para o cliente, não importa se a solução vem de várias empresas ou de uma megaempresa. Segundo PERELMAN (1999), uma das conclusões de uma pesquisa realizada com 96 executivos seniores da indústria de telecomunicações pela Ernst \& Young:

"The key industry driver is not technology, nor the convergence of technology, nor the rapid change in pricing and price points. Rather it is the customer and the needs and desired behaviors that the customer wants - or perhaps has always wanted. Technology is the enabler which allows us to fulfill those unmeet needs, and regulation is the wild card"

Portanto, a pergunta que se pretende responder no desenvolvimento desta pesquisa é a seguinte: "qual foi o efeito da diversificação no valor das empresas do setor de telecomunicações de acordo com a metodologia desenvolvida por BERGER e OFEK?" 
Para se alcançar o objetivo estabelecido, será utilizada a metodologia desenvolvida por BERGER e OFEK (1995) apresentada na seção III Metodologia de Pesquisa.

\section{I.4. OBJETIVOS DE PESQUISA}

O objetivo principal deste estudo é verificar se a ampliação do portfolio de produtos e serviços da indústria de telecomunicações através de fusões e aquisições está criando ou destruindo valor para o acionista, ou seja, qual o impacto sobre o valor para o acionista conforme o modelo de BERGER e OFEK. A verificação da ampliação ou redução do portfolio de produtos e serviços será através do número de unidades estratégicas de negócios (UEN) das empresas. Quanto maior for a quantidade de UEN, mais diversificada ela será.

A importância deste estudo advém dos vários estudos realizados até o momento mas que não tratam, como se pretende neste estudo, de um setor específico da economia.

As empresas de telecomunicações apresentam várias características que favorecem a operação de fusões e aquisições no sentido de lançarse no mercado como compradoras dada a disponibilidade de caixa e capacidade de endividamento e, concomitantemente, mostra-se em circunstâncias que podem representar perda de valor através da diversificação e investimentos em projetos com valor presente líquido negativo.

Embora a convergência tecnológica envolva diferentes indústrias, pretende-se analisar apenas um segmento da cadeia produtiva no setor estudado, conhecido como vendors. As empresas de telecomunicações a serem estudadas são as fornecedoras de equipamentos e serviços às operadoras de telefonia fixa e móvel. O uso de dados do mercado brasileiro neste estudo é inviável por pelo menos três razões principais: 
não há empresas matrizes deste setor aqui estabelecidas, as empresas aqui presentes não se encontram listadas nas Bolsas de Valores e as operações de fusões e aquisições são realizadas pela matriz e, geralmente, acompanham uma operação mundial. Para a realização deste trabalho utilizou-se os dados secundários do mercado de ações norte-americano disponíveis através das empresas: Securities Data Company, Compustat Industry Segment (CIS) e Bloomberg. Estas empresas possuem um banco de dados suficientemente abrangente para o escopo deste trabalho.

\section{I.5. HIPÓTESES}

A hipótese $\mathrm{H}_{0}$ que é levantada tem em vista o estudo realizado por COMMENT e JARREL (1995) que indica a reversão do processo de diversificação em vários setores dada a redução do valor da empresa.

$\mathrm{H}_{0}$ : A onda de fusões e aquisições que o mercado de telecomunicações está enfrentando não está agregando valor ao acionista através da diversificação.

$\mathrm{H}_{1}$ : $\mathrm{O}$ processo de fusões e aquisições no mercado de telecomunicações está agregando valor ao acionista através da diversificação.

Uma das justificativas, alegada por alguns, para que a diversificação esteja ocorrendo com os fornecedores de telecomunicações seja a estratégia de seguir o mercado, ou seja, um concorrente realiza a fusão ou aquisição porque o seu concorrente também está fazendo.

\section{I.6. DEFINIÇÃO CONCEITUAL E OPERACIONAL}

A fim de se desenvolver o estudo, é necessário apresentar a definição conceitual e operacional dos termos que constam na pergunta de pesquisa que se encontra no final da definição da situação problema: 
- fusões: adota-se o conceito apresentado por ROSS, WESTERFIELD e JAFFE (1995) que define como absorção de empresa por outra, onde a empresa compradora conserva seu nome e sua identidade, e adquire todos os ativos e passivos da empresa comprada e a empresa adquirida deixa de existir como entidade independente;

- aquisições: adota-se o conceito apresentado por ROSS, WESTERFIELD e JAFFE (1995) que define como sendo a aquisição de todos os ativos de uma empresa por outra, envolvendo, portanto, a transferência da propriedade dos ativos;

- mercado de telecomunicações: empresas fornecedoras de equipamentos e serviços para as operadoras de telefonia, quer sejam móveis ou fixas, também conhecidas como vendors;

- diversificação: ampliação do portfolio de produtos e serviços das empresas de telecomunicações com produtos e serviços das empresa de informática (hardware e software). A diversificação será constatada quando houver o aumento na quantidade de UEN de uma empresa.

- Unidade Estratégica de Negócio (UEN): unidades de negócio legalmente independentes mas que são controladas por uma mesma empresa-mãe.

- agregar valor ao acionista: medido pelo logaritmo natural da razão entre valor real de uma empresa e seu valor atribuído conforme o modelo de BERGER e OFEK (1995).

\section{I.7. ORGANIZAÇÃO DO ESTUDO}

A estrutura deste estudo compreende 0 desenvolvimento da fundamentação teórica e apresentação da metodologia de pesquisa a ser utilizada.

O capítulo II - Fundamentação Teórica inicia-se com a apresentação das formas de alocação de recursos e a decisão de investimentos dos 
mesmos. Dentre as diversas formas de combinar os investimentos, apresenta-se a possibilidade de diversificação motivada pela redução do risco do empreendimento e quais são os problemas destacados pela literatura.

Dentre as possibilidades de diversificação do investimento em empresas, apresentam-se os resultados de diversificações em empresas correlatas e não-correlatas e diversificação em empresas de serviços.

São apresentados trabalhos que indicam o direcionamento das empresas para a especialização de suas atividades.

Dado que o presente estudo pretende abordar o processo de fusões e aquisições como uma das possibilidades de diversificação, discute-se quais são os tipos de aquisições abordadas pela literatura, a controvérsia existente entre o desenvolvimento interno de competências e a aquisição em outras empresas e, discute-se brevemente, a opção por alianças estratégicas como forma de se aproveitar de competências inexistentes na empresa. Em seguida, são abordadas diferentes correntes teóricas sobre fusões e aquisições tendo em vista que não se tem uma teoria ainda definida e genericamente aceita.

É apresentada a evolução e importância que o setor eletroeletrônico teve na economia, principalmente após a 2a. Guerra Mundial, destacando-se a relevância das telecomunicações até se explicar o motivo da diversificação das empresas.

Ainda dentro do capítulo II discute-se o objetivo convencional na teoria de finanças corporativas que é maximizar o valor da firma e formas de se medir o valor da empresa. Nesta parte do estudo trata-se do fluxo de caixa, lucro econômico e lucro contábil, economic value added e market value added e medidas de desempenho utilizadas na avaliação. Este capítulo é encerrado com a discussão das técnicas de análise de valor e 
engenharia de valor que tiveram início durante a última guerra mundial e foram consolidadas efetivamente nos Estados Unidos entre 1947 e 1952 e com apresentação da taxa de desconto e custo de capital.

O capítulo III - Metodologia de Pesquisa apresenta as duas equações a serem utilizadas para se avaliar a criação ou destruição de valor das empresas diversificadas. São utilizados três múltiplos (vendas, ativos e LAJIR) nesta avaliação como forma de verificação da variação de valor. Porém, antes de apresentá-las, discute as metodologias existentes com relação à natureza da variável pesquisada e ao objetivo e ao grau em que o problema de pesquisa está cristalizado assim como os tipos de pesquisas a saber: exploratória, conclusiva descritiva e casual.

Finalmente, apresenta-se a amostra pesquisada, estratégia de coleta dos dados, forma de tratamento e análise dos mesmos, instrumentos de medidas a serem utilizados e limitações do método.

O Capítulo IV - A Pesquisa identifica a amostra através dos principais segmentos e discute os critérios utilizados para exclusão dos dados preliminares coletados que foram o nível mínimo de faturamento líquido, problemas de validação, LAJIR negativo, empresas com UEN no setor financeiro e valores extremos. Ao final desta parte, apresenta-se a amostra final utilizada durante todo o estudo.

Após definir a amostra final, analisa-se as suas características do ponto de vista dos segmentos e da quantidade de UEN que a constituem. Realiza-se então, os testes de hipóteses para número médio de UEN, caracterização do subgrupo de diversificação, valor médio dos múltiplos ano a ano e verificação da teoria.

Dado a relevância do assunto e dado que é também uma forma de medida, discute-se o fluxo de caixa da amostra final obtido através da soma do LAJIR e depreciação. Conclui-se o capítulo IV com a aplicação 
dos múltiplos de acordo com o modelo proposto por BERGER e OFEK e compara-os entre si.

O capítulo $\mathrm{V}$ - Considerações Finais encerra o trabalho com sugestões de novas pesquisas e limitações deste trabalho. 
Capítulo II:

FUNDAMENTAÇÃO TEÓRICA 


\section{FUNDAMENTAÇÃO TEÓRICA}

\section{II.1. ALOCAÇÃO DE RECURSOS E MOTIVOS DE INVESTIMENTOS}

Algumas definições abrangentes de riqueza referem-se à capacidade que o indivíduo tem de adquirir bens e serviços. Numa economia monetária, a medida de riqueza é o valor do dinheiro, ou a soma dos pertences a preço de mercado caso fossem vendidos. Os pertences que um indivíduo legalmente possui podem variar de forma tais como dinheiro, investimentos no mercado financeiro, consumo de bens e serviços. Para SMITH (1971), a riqueza é representada pelo investimento nestas diferentes formas. A composição da riqueza é uma conseqüência da sua escolha, quer seja através de uma análise e deliberação ou simplesmente por inércia. Como o ambiente é dinâmico e imprevisível, e a disponibilidade de tempo para realizar investimentos é escassa, o investidor está constantemente escolhendo, observando e reavaliando as alternativas existentes.

As decisões de investimentos nestas diferentes formas estão baseadas na avaliação feita sobre os possíveis resultados das possibilidades conhecidas. De maneira geral, o investidor espera obter um resultado melhor através de investimentos realizados do que não realizar investimentos ou mesmo superar as outras combinações de investimentos possíveis. Com a sua decisão, o investidor espera obter uma satisfação financeira maior no futuro que no presente mantendo o seu poder de compra. Além desta preocupação, o investidor também está interessado no quanto representa esta satisfação futura, qual a sua freqüência e a negociabilidade dos seus investimentos. SMITH (1971) conclui que a decisão de investimento é resultado de três fatores diferentes mas relacionados. O primeiro fator se refere às informações que estão disponíveis em diferentes formas e fontes tanto privadas 
como públicas. O segundo fator é determinado pelas expectativas dos resultados das alternativas de investimentos disponíveis que são subjetivas muito embora sejam baseadas no ambiente e nos fatos financeiros disponíveis. O terceiro e último fator na visão desse autor é descrito como a precificação que inclui o tamanho e regularidade dos retornos a serem recebidos e a segurança e negociabilidade do investimento.

Para HARRIS, KRIEBEL e RAVIV (1982), há dois aspectos do ambiente que tornam a alocação de recursos e coordenação das atividades da empresa importantes e difíceis. Primeiramente, eles reconhecem que na maioria das empresas há várias atividades realizadas e gerenciadas por diferentes indivíduos, cada um com suas informações e experiências concernentes as suas próprias esferas de atuação. Geralmente, esta informação não está disponível para outros indivíduos da empresa, incluindo a alta administração. Segundo, os indivíduos com informações particulares também têm interesses que podem divergir daqueles da empresa e, desta forma, podem achar desvantajoso revelar as informações privilegiadas para a alta administração.

Para entender a importância destes dois aspectos na alocação de recursos, considere uma empresa onde a alta administração possui todas as informações disponíveis. Neste caso, haverá uma imposição por parte da alta administração para alocação de recursos em toda a empresa. Porém, se houver assimetria de informação, a imposição de alocação de recursos poderá não ser ótima dado que não se dispõe de toda a informação. Numa situação onde há assimetria de informação mas não há divergência de interesses, a alta administração pode solicitar à gerência que realize a alocação de recursos de forma otimizada. 
Os autores concluem que a presença de assimetria de informações e divergência de interesses introduz uma troca entre delegar decisões para a baixa administração que dispõe das informações privilegiadas e a conseqüência de ter as decisões baseadas em interesses particulares e sugerem um mecanismo para resolver esta questão de forma ótima tendo o preço de transferência como um mecanismo de minimização de custo.

\section{II.2. DIVERSIFICAÇÃo COMO REDUÇÃO DE RISCO}

A redução da variabilidade dos ganhos pode levar a empresa a vantagens operacionais e de planejamento e pode aumentar a sua capacidade de endividamento através da redução da taxa de inadimplência esperada. Esta conclusão é atribuída a LEWELLEN (1971) que afirma que empresas diversificadas usarão mais capital de terceiros devido a redução da expectativa de inadimplência oriunda da diversificação. AMIHUD e LEV (1981) sustentam que os executivos se beneficiam da redução de risco associado com a diversificação pois sofrem menos risco de serem demitidos. Através da redução da volatilidade, a diversificação da empresa pode potencialmente aumentar o seu valor através da redução do custo de agência. STULZ (1990) defende que quanto maior a volatilidade do fluxo de caixa maior o custo de agência e assim, reduz-se o valor da empresa. Esta redução em valor ocorre devido a maior volatilidade ou incerteza sobre os fluxos de caixa futuros e maior dificuldade em identificar e manter uma estrutura ótima de capital que balanceia os custos de superinvestimentos devido aos poucos empréstimos de terceiros. JENSEN (1986) discute sobre esta redução identificando o problema do fluxo de caixa livre e MYERS (1977) discute os custos de subinvestimentos devido aos muitos empréstimos de terceiros. 
A diversificação é freqüentemente mencionada como um benefício da aquisição de uma empresa por outra. Para ROSS, WESTERFIELD e JAFFE (1995), não é incomum observar empresas com fundos excedentes articulando uma necessidade de diversificação. Entretanto, a diversificação, por si só, não é capaz de produzir aumentos de valor. Pode-se perceber este fato verificando a variabilidade da taxa de retorno de uma empresa que é composta pela sua especificidade (não sistemática) e pela parte comum a todas as empresas (sistemática).

A variabilidade sistemática não pode ser eliminada com a diversificação, e por isso as fusões não são capazes de extinguir este risco. Ao contrário, o risco não sistemático pode ser reduzido com a diversificação resultante de fusões. Entretanto, o investidor pode realizar a diversificação com muito mais facilidade através da compra de ações de empresas diferentes. Evidências empíricas indicam que a diversificação pode prejudicar os acionistas. MORK, SHLEIFER e VISHNEY (1990) mostram que o patrimônio dos acionistas teve mal desempenho em empresas que se diversificaram via aquisição na década de 80 . Portanto, a diversificação através da formação de conglomerados pode não beneficiar os acionistas.

Para ROSS (op.cit), a diversificação poderá produzir ganhos para a empresa adquirente somente se duas situações forem verdadeiras:

a. a diversificação produzir a variabilidade não sistemática a custos menores do que os custos que seriam incorridos pelos investidores ao ajustarem suas carteiras pessoais, o que parece pouco provável;

b. a diversificação reduz riscos e, portanto, aumenta a capacidade de endividamento. 


\section{II.3. PROBLEMAS NA DIVERSIFICAÇÃO}

A assimetria de informação entre os executivos e os acionistas conduz aos investimentos ineficientes quando o fluxo de caixa é baixo pois os executivos não conseguem convencer os acionistas de que os recursos são insuficientes para obter vantagens de todas as oportunidades de projetos com valor presente líquido positivo. Para STULZ (1990), os executivos dizem aos acionistas que a empresa não pode usufruir todas as vantagens que seriam proporcionadas caso houvesse investimentos em todas as oportunidades de projetos com valor presente líquido positivo. Porém, os acionistas não aceitam a argumentação de que o fluxo de caixa é baixo, pois os executivos se beneficiam com o aumento de investimento mesmo quando a empresa investe em projetos com valor presente líquido negativo pois evita pagamento de dividendos.

A obtenção de empréstimos de terceiros força os executivos a destinarem parte do fluxo de caixa ao pagamento da dívida e assim reduzir as possibilidades de investimentos. Estes pagamentos afetam a riqueza do acionista tanto positivamente, através da redução de investimentos que poderiam ser muito elevados, como negativamente, através da inibição de vantagens oriundas de novos investimentos. Esta troca entre os custos e os benefícios de contrair dívida para realizar novos investimentos implica na possibilidade de se discutir a existência de um ponto que maximiza o valor da empresa. STULZ (1990) mostra em sua análise que a relação entre capital de terceiros e capital próprio depende criticamente da probabilidade de distribuição do fluxo de caixa e das oportunidades de investimentos da empresa. Em particular, os acionistas de uma empresa com expectativas de fluxo de caixa livre negativo e poucas oportunidades de investimentos podem desejar obter empréstimos para investir nestes poucos projetos e, da mesma forma, acionistas de empresas com fluxo de caixa livre positivo e boas 
oportunidades de investimentos também podem desejar que os executivos tomem empréstimos para diminuir a probabilidade de que algum projeto com valor presente líquido positivo não receba investimentos. Fluxos de caixa mais voláteis, ou seja, que apresentam uma distribuição de probabilidade mais dispersa, aumentam a probabilidade de se incorrer em superinvestimentos ou subinvestimentos ocasionando custos e reduzindo o valor da empresa para todos os níveis da estrutura de capital. Este fato sugere que a diversificação de investimentos através de projetos reduz o custo de agência pois torna o fluxo de caixa total da empresa mais previsível.

\section{II.4. DIVERSIFICAÇÃO EM EMPRESAS CORRELATAS E NÃO-CORRELATAS}

RUMELT (1974), no seu trabalho original, concluiu que empresas diversificadas correlatas apresentam um melhor desempenho que as empresas diversificadas não-correlatas. A partir deste trabalho, inúmeros outros trabalhos surgiram contestando os resultados, apoiando ou sendo indiferentes. Diante desta variedade de conclusões, CHATTERJEE e WENERFELT (1991) indagaram se a diversificação de empresas não-correlatas é uma melhor alternativa em determinadas circunstâncias muito embora na média elas pareçam ser inferiores. Para isto, desenvolveram um estudo verificando a idéia de que as empresas diversificam em parte para utilizar os recursos produtivos que são excedentes da operação atual de forma a permitir predições quanto à direção de expansão da empresa, ou seja, se é através de empresas correlatas ou não. A preocupação não era verificar o motivo da diversificação das empresas mas sim o tipo de mercado que as empresas escolhiam entrar. Uma vez ocorrida a decisão de diversificação, o tipo de mercado escolhido deve ser tal que a empresa tenha vantagem competitiva. PORTER (1987) sugere que uma empresa 
pode obter ganhos através de vantagens competitivas se tiver habilidades ou recursos que possam ser transferidos para o novo mercado. Portanto, o tipo de diversificação esperado está na dependência da especificidade do recurso. Se o recurso for usado apenas para produzir um tipo de produto, não se pode esperar uma diversificação. Contudo, muitos recursos podem ser usados para mais de um produto final. Estes recursos podem ser físicos (plantas e equipamentos), intangíveis (marca e capacidade de inovação) ou financeiros sendo que os dois primeiros são mais restritos conduzindo a empresa a um processo de diversificação em empresas correlatas. $O$ terceiro tipo de recurso é útil para qualquer tipo de diversificação. Porém, dado que os recursos financeiros podem ser subdivididos em dois grupos, recursos gerados internamente e recursos obtidos externamente, espera-se que o mercado de capitais forneça recursos para diversificações em empresas correlatas por ser menos arriscadas que diversificações em empresas não-correlatas. Logo, pressupõe-se que os recursos internos são destinados às diversificações nãocorrelatas. Se este tipo de diversificação é verdadeiramente nãorentável, então, a única razão pela qual os executivos realizam a diversificação é aumentar o tamanho da empresa e seus poderes como prediz a Teoria da Agência. Mas, e se os executivos estiverem realmente preocupados em maximizar a riqueza do acionista? O único motivo que poderia conduzir o executivo a decidir pela diversificação através de empresas não-correlatas seria se 0 mesmo estivesse convencido que ele pode investir em projetos que ex-post aumentariam a riqueza do acionista. Contudo, dado que o mercado de capitais reluta em aceitar este tipo de diversificação, o executivo encontra-se frente a uma situação onde a informação sobre o projeto é desconhecida ou não aceita ex-ante. MYERS e MAJLUF (1984) sugerem que diante desta 
diferença de informações, o executivo deveria utilizar os recursos internos para financiar os projetos em diversificação não-correlata e recursos externos para diversificações correlatas.

De acordo com o resultado do trabalho de CHATTERJEE e WENERFELT (1991), os recursos intangíveis e financeiros são fatores dominantes na explicação do tipo de diversificação que a empresa opta fornecendo uma vantagem competitiva na diversificação correlata. A relação entre liquidez de longo prazo e diversificação não-correlata também foi verificada e confirma os estudos em administração estratégica que afirmam que a este tipo de diversificação é considerada mais arriscada pelo mercado de capitais. Não houve resultados que suportassem a hipótese de que a disponibilidade de recursos externos conduzisse a uma diversificação correlata.

\section{II.5. DIVERSIFICAÇÃO EM EMPRESAS DE SERVIÇOS}

NAYYAR (1993) examinou o desempenho de empresas prestadoras de serviços que apresentavam uma diversificação correlata. Ele estudou a reação do mercado de capitais frente ao movimento de diversificação das empresas prestadoras de serviço que buscavam os benefícios devido à assimetria de informação e economia de escopo. A conclusão foi que nem sempre estes benefícios são alcançados completamente devido às dificuldades de implementação discutidas a seguir. Resumidamente: (1) as empresas que buscavam o benefício da assimetria de informação foram mais valorizadas pelo mercado de capitais que as empresas que buscavam as economias de escopo; (2) empresas que já eram reconhecidas pelos seus serviços prestados foram mais valorizadas pelo mercado de capitais quando buscavam o benefício da assimetria de informação que as empresas que não possuíam este reconhecimento do mercado; (3) as empresas novas no 
mercado (ou seja, que ainda não eram reconhecidas pelos serviços prestados) que buscavam as economias de escopo foram mais valorizadas pelo mercado de capitais que as empresas já reconhecidas; (4) as empresas reconhecidas que buscavam as economias de escopo foram valorizadas negativamente pelo mercado de capitais.

As empresas prestadoras de serviços diversificadas podem se beneficiar da assimetria de informações entre elas próprias e entre os consumidores dos serviços. Os consumidores realizam a decisão de compra do serviço baseados no preço e qualidade das alternativas disponíveis. Contudo, a qualidade de um serviço é difícil de se avaliar devido a sua intangibilidade e a simultaneidade da produção e consumo, o que dificulta a decisão de compra. Assim sendo, os consumidores buscam informações para realizarem uma melhor escolha. Geralmente, as empresas de serviços possuem mais informações que seus consumidores sobre a qualidade dos serviços prestados. Esta assimetria de informação conduz ao "moral hazard" para as empresas prestadoras de serviços, dando-Ihes um incentivo para não empenharem todos os seus esforços para entregar o melhor serviço.

Quando os consumidores precisarem avaliar empresas prestadoras de serviços para outras necessidades, eles podem economizar no custo de aquisição de informações através da preferência pelo atual prestador de serviço com o qual eles já estão satisfeitos, desde que ele seja diversificado. Para o prestador de serviço, pode ser mais fácil influenciar o atual consumidor ou com quem ela já teve uma relação favorável na decisão de nova compra que obter novos clientes. Para o consumidor, a reputação reduz algumas das conseqüências adversas originadas pela assimetria de informações. As empresas diversificadas podem obter uma vantagem competitiva através do atendimento de múltiplas necessidades do consumidor satisfeito. Contudo, a falha em atender as 
suas necessidades pode também afetar negativamente a imagem de outros serviços, mesmo que o consumidor não o tenha ainda adquirido.

A economia de escopo está presente quando a soma do custo de produção de dois ou mais itens é menor que a soma dos custos de produção destes itens separadamente. Este benefício surge quando as unidades de negócio dividem o mesmo fator de produção que pode ser o sistema de gerenciamento ou distribuição, tecnologia de processo ou produto, uma planta ou equipamento.

A distribuição destes fatores implica uma redução mas as economias de escopo surgem quando uma empresa diversificada independentemente utiliza-se da mesma quantidade de recursos em várias unidades de negócio como é o caso da tecnologia, que não é dividida mas utilizada igualmente para diversas unidades.

As empresas prestadoras de serviço podem se beneficiar das economias de escopo de diversas formas. Por exemplo, as empresas que estão no negócio de hotelaria podem utilizar sua experiência em acomodações para oferecem serviços similares aos hospitais ou ainda, restaurantes comerciais podem oferecer seus serviços para empresas, hotéis, restaurantes e outros estabelecimentos que necessitam do preparo da alimentação.

Contudo, os potenciais benefícios da assimetria de informações e das economias de escopo não implicam nas suas realizações. Os benefícios oferecidos pela assimetria de informações requerem a minimização dos custos de contaminação de imagem que podem surgir com a mistura de serviços de diferentes qualidades ou que servem os consumidores de maneiras diferentes em um mesmo segmento de mercado. Já as economias de escopo requerem um estabelecimento de relações problemáticas e custosas entre as unidades de negócio. Isto se deve aos custos de transação internos, que são os custos de negociação, 
monitoramento e acordos entre as partes (neste caso, unidades de negócio da mesma empresa) numa relação de troca. Estes custos existem porque existem diferentes interesses a serem atendidos e a cooperação entre as partes é que determinará o atingimento das economias de escopo ou não.

NAYYAR (1993) também apresenta um resumo sobre outras barreiras organizacionais para 0 atingimento da cooperação dentro das organizações prestadoras de serviços: (1) falta de comunicação entre as unidades sobre as intenções de se alcançar benefícios mútuos; (2) falta de detalhamento do plano de ação para alcançar estes benefícios; (3) percepção ou real perda da independência e autonomia que a parceria pode trazer; (4) resistência em aceitar compromissos embora as partes possam atingir resultados globais melhores; (5) dificuldade no aprendizado da organização que impede a entrada em novas atividade; (6) dificuldades associadas com a transferência de tecnologia se uma nova unidade é esperada obter ganhos usando tecnologia altamente especializada; e (7) convenções contábeis não adequadas para a alocação de custos e benefícios.

\section{II.6. DA DIVERSIFICAÇÃO À ESPECIALIZAÇÃO}

O início da década de 80 marcou o final de uma tendência de diversificação das empresas que se iniciou no final dos anos 50 e intensificou-se na década seguinte. Nesta nova etapa da estratégia de crescimento das empresas, os executivos começaram a se preocupar em reduzir a diversidade das empresas concentrando-se no core business. A nova estratégia foi a de especialização através de desinvestimentos e reestruturações.

A estratégia de crescimento através da diversificação era suportada por vários trabalhos acadêmicos que identificam, entre outras vantagens, as 
economias de escala na área administrativa, economias de escopo em produção e marketing e sinergia financeira alcançada pelo desenvolvimento do mercado financeiro interno.

As economias de escala variam substancialmente entre as empresas dos diferentes setores de atividade econômicas. Outros fatores permanecendo constantes, quanto mais substanciais forem as economias de escala, provavelmente maiores serão as empresas de um determinado setor. Tipicamente, as empresas do setor de transformação têm maior probabilidade de apresentarem rendimentos crescentes de escala do que as empresas do setor de serviços, pois a atividade de transformação exige substanciais investimentos em equipamentos de capital para que tais empresas possam operar da forma mais eficaz (PINDYCK e RUBINFELD, 1994). Porém, no caso das diversificações de empresas, os argumentos se baseavam em economias de escala na área administrativa, o que invalida a comparação entre economia de escala e tamanho da empresa pois as empresas podem atingir praticamente o mesmo nível de economia.

Muitas empresas produzem mais que um produto que podem ou não ser fisicamente relacionados. Em ambas as circunstâncias, porém, as empresas provavelmente terão vantagens de produção ou de custo quando produz dois ou mais produtos, em vez de apenas um. Tais vantagens poderiam advir do uso de insumos ou de instalações de produção, de programas conjuntos de marketing, ou possivelmente da economia nos custos de uma mesma administração. Em alguns casos, a produção de um produto resulta em um subproduto inevitável que tem valor para a empresa como é o caso do fabricante de chapas de aço que gera sucata de metal e rebarbas que podem ser vendidas. As vantagens econômicas da produção conjunta são chamada de economias de escopo. Segundo PYNDICK e RUBINFELD (1994): 
"as economias de escopo encontram-se geralmente presentes quando a produção conjunta de uma única empresa é maior do que as produções obtidas por duas empresas diferentes, cada uma produzindo um único produto (com equivalentes insumos de produção alocados entre as duas empresas separadas)

Caso uma empresa apresente uma produção conjunta que seja menor do que a obtida por empresas separadas, então tal processo de produção envolve deseconomias de escopo.

Não existe relacionamento direto entre economias de escala e economias de escopo. Uma empresa fabricante de dois produtos poderia ter vantagens decorrentes de economias de escopo, mesmo que seu processo produtivo envolvesse deseconomia de escala.

A ênfase na especialização é consistente com JENSEN (1988) que argumenta que os programas de diversificação das empresas exemplificam a teoria de que os executivos de empresas com possibilidade de aumentar seu endividamento e grandes quantias de fluxo de caixa livres são mais susceptíveis a investimentos com destruição de valor. Similarmente, MEYER, MILGORM e ROBERTS (1992) sustentam que empresas que apresentam resultados ruins tiveram anteriormente acesso aos recursos disponíveis da empresa controladora.

De acordo com o estudo de COMMENT e JARRELL (1995), há uma pequena tendência em direção à busca da especialização pelas empresas norte-americanas durante a década de 80. Em 1988, 55.7\% das empresas estudadas tinham apenas uma unidade de negócio comparado com $38,1 \%$ em 1979. Além da tendência em direção a especialização, o estudo revela que houve uma relação positiva entre retorno das ações e aumento do foco e uma falha das empresas diversificadas em explorar economias financeiras de escopo. 
A combinação de negócios que tenham correlação imperfeita de ganhos reduz a variabilidade dos mesmos. Riscos menores não são provavelmente interessantes per se para os acionistas, que podem diversificar através de portfolios próprios de ações. A habilidade do investidor em diversificar através de investimentos pessoais tem crescido nos últimos anos devido a redução dos custos de transação e do crescimento da indústria de fundos mútuos, o que pode ter levado a reduzir o motivo ou desejo de diversificação das empresas. LEVY (1991) argumenta que a habilidade dos acionistas e intermediários financeiros em montar portfolios pode ter diminuído o movimento de diversificações nas empresas.

Uma possível motivação para o desinvestimento é aumentar o foco na operação da empresa vendedora de forma a melhorar o desempenho dos ativos restantes. Esta melhora pode ser devido a várias razões tais como a eliminação de sinergias negativas com o ativo vendido ou aumento na eficiência através de uma melhor alocação dos recursos de gerenciamento.

Num mercado de capitais eficiente onde os executivos procuram maximizar o valor da empresa, as empresas vendem seus ativos para outros por duas razões principais. Primeiramente, o ativo tem uma melhor utilização e é de maior valor na empresa que o comprou do que na empresa que o vendeu. Segundo, o ativo vendido interfere em outras operações da empresa vendedora. Um importante caso é quando o ativo vendido não está relacionado com a operação principal da empresa. A venda deste ativo conduz a um aumento no foco da empresa e a uma operação mais eficiente naquilo que a empresa sabe fazer de melhor. JOHN e OFEK (1995) realizaram estudo enfatizando o foco da empresa como um motivo importante para o desinvestimento. A hipótese do foco da empresa implica que a eliminação das sinergias 
negativas entre 0 ativo a ser vendido e os ativos restantes poderiam conduzir a uma melhor performance a estes últimos após o desinvestimento. Eles constataram que o ganho de valor originou-se de uma melhor administração dos ativos remanescentes após o desinvestimento. Através de uma série de testes para determinar se o foco da empresa é uma importante explicação ou não para os ganhos do vendedor, encontraram-se várias evidências consistentes com a hipótese do foco: a operação da empresa vendedora tornou-se mais especializada no ano do desinvestimento; houve um aumento no índice de Herfindahl; uma diminuição no número de linhas de negócios reportado; e finalmente, em $75 \%$ dos casos, a divisão onde ocorreu o desinvestimento não era relacionada com a operação principal da empresa. Utilizando-se de diversos medidores contábeis de desempenho tais como margem operacional e retorno sobre ativos, verificou-se que os ativos remanescentes eram mais rentáveis após o desinvestimento concluindo-se que a melhora no desempenho está positivamente relacionada com o aumento do foco da empresa.

\section{II.7. O PROCESSO DE FUSÕES E AQUISIÇÕES COMO DIVERSIFICAÇÃO}

As empresas diversificadas que se utilizam do planejamento estratégico para vislumbrar a sua sobrevivência no longo prazo constantemente se deparam com a opção de aquisição contra o desenvolvimento interno para alcançar o crescimento. Esta sobrevivência depende da sua habilidade em desenvolver pontos fortes em relação aos seus competidores que, por conseguinte, também depende da habilidade em alocar recursos de unidades bem estabelecidas ou maduras para negócios emergentes com potencial de crescimento. Através deste processo de rejuvenescimento a empresa deve decidir se, dado a sua 
estratégia básica, é melhor alocar estes recursos para aquisição ou se é melhor redistribuí-los entre as unidades de negócio já existentes.

Para JENSEN (1986), o processo de aquisição é uma forma dos executivos utilizarem os recursos disponíveis ao invés de pagarem dividendos aos acionistas. Estes recursos disponíveis são provenientes do fluxo de caixa gerado em excesso pelos projetos que têm valor presente líquido positivo quando descontados à taxa do custo de capital. Após a empresa realizar todos os seus investimentos em projetos com valor presente líquido positivo, o fluxo de caixa que ainda restar é chamado de fluxo de caixa livre (free cash flow).O autor discute como evitar que os executivos invistam em projetos com valores presentes líquidos negativos ou em ineficiências organizacionais ao invés de pagar dividendos aos acionistas. As duas primeiras situações podem também ocorrer devido à possibilidade da empresa aumentar o seu endividamento. Jensen ainda destaca que o processo de diversificação, segundo a teoria existente, produz ganhos totais menores e que, eventualmente, o maior benefício desta transação seja desperdiçar menos recursos do que os exigidos em projetos não-lucrativos.

As empresas diversificadas podem apresentar uma hierarquia de estratégias de negócio podendo o processo de rejuvenescimento estratégico ocorrer em cada um destes níveis hierárquicos: portfolio, família de negócios e elemento de negócio.

Para LORANGE, KOTLARCHUCK e SINGH (1994) o incentivo para compra de uma unidade de negócio existe quando o processo de aquisição conduz a uma maior eficiência em termos de custos que o desenvolvimento interno deste tipo de negócio. Portanto, para que a aquisição seja viável, duas condições devem ser aplicadas: 
- o preço que é pago deve ser menor que o total de recursos necessários para o desenvolvimento interno, mantendo-se o mesmo nível de posição estratégica

- a antecipação dos benefícios deve refletir a geração de valores futuros.

Embora óbvio, a empresa que está realizando a aquisição deve considerar cuidadosamente o que está comprando e como esta aquisição se encaixa na sua organização. A empresa deve responder as perguntas tais como o tipo de competência que se está adquirindo, qual a sua produtividade e possibilidade de se obter sinergias. O processo de planejamento da aquisição pode expor uma variedade de razões que conduzam a certificação de que se está tomando a melhor atitude assim como antecipar os benefícios da combinação de unidades de negócio.

\section{II.7.1. TIPOS DE AQUISIÇÕES}

De acordo com WESTON, CHUNG e HOAG (1990), os diferentes tipos de aquisição podem ser classificados em horizontal, vertical, concêntrico ou não relacionadas (conglomerados).

As aquisições horizontais ocorrem quando uma empresa adquire outra na mesma indústria. Os principais benefícios neste tipo de aquisição são as economias de escala na produção e distribuição e a possibilidade de aumentar o poder de barganha no mercado através de uma concentração maior na indústria.

As aquisições verticais acontecem quando as empresas envolvidas no processo pertencem a indústrias com um forte relacionamento entre fornecedor e comprador. A empresa que está comprando é uma fornecedora ou cliente da empresa que está sendo comprada. Este tipo de aquisição ocorre quando o mercado para um produto intermediário é imperfeito devido à escassez de recursos, dificuldade em adquiri-los, 
controles sobre as especificações da produção de um produto intermediário, entre outras razões.

As aquisições concêntricas ocorrem quando as empresas envolvidas estão relacionadas através de tecnologias básicas, processos de produção ou mercados. A empresa que está sendo comprada representa uma extensão da linha de produtos, participação no mercado ou tecnologia da empresa que está comprando. Os benefícios deste tipo de aquisição podem ser citadas como as economias de escopo, usandose do compartilhamento de recursos obtendo-se resultados melhores que a situação inicial.

As aquisições não relacionadas ou de conglomerados não objetivam explicitamente um compartilhamento de recursos, tecnologias, sinergias ou estratégias de produtos e mercados. Na verdade, o foco é como a empresa compradora pode manter a estabilidade e balanço do seu portfolio em termos de uma melhor utilização e geração de recursos.

\section{II.7.2. A CONTROVÉRSIA ENTRE DESENVOLVIMENTO INTERNO E} AQUISIÇÃO

A escolha entre desenvolvimento interno e aquisição é determinada basicamente pelos custos e benefícios que poderão ser gerados. $O$ processo de aquisição significa recursos que irão ser deslocados das unidades de negócio para pagar a transação. Dado que estes recursos poderiam estar sendo utilizados para desenvolvimento interno, a organização poderá resistir ao uso de recursos para compras externas possibilitando o surgimento da desmotivação da mesma. Outra fonte potencial para criação de perda de motivação é o distúrbio que um processo deste inevitavelmente causa. Novas pessoas devem ser integradas à organização, novas definições nas estruturas gerenciais, criação da tensão humana e gasto de energia da organização. 
Por estes fatos e pelo motivo do planejamento estratégico de aquisição ser altamente subjetivo, o sucesso relativo ou vantagens de um processo de aquisição pode estar sujeito a controvérsias dentro da organização, dependendo do ponto de vista de seus vários elementos. Os executivos podem visualizar como vantagens o acréscimo de competência, desenvolvimento de pontos fortes competitivos ou incremento do escopo de uma unidade já existente. Estes fatores poderão gerar benefícios futuros mas podem criar problemas no curto prazo conforme descritas anteriormente. Contudo, os membros da organização abaixo dos executivos podem não dividir este mesmo entusiasmo. Os acionistas podem desejar a aquisição se ela realmente oferecer um acréscimo de valor no longo prazo para suas holdings ou maximizar seus lucros.

\section{II.7.3. A BUSCA PELO CONTROLE CORPORATIVO}

Para BOISI e ESSIG (1994), as forças que direcionam o mercado para o controle corporativo podem ser divididas em duas partes como 0 balanço patrimonial de uma empresa: componente do ativos e componentes relacionados ao financiamento. Os componentes relacionados aos ativos envolvem a oferta e demanda de recursos estratégicos escassos que incluem terra, equipamento, recursos naturais, propriedade intelectual e talento administrativo. As forças relacionadas aos componentes de financiamento incluem o nível de taxas de juros reais, a viabilidade de obter um capital de risco, liquidez do mercado bancário, disponibilidade de crédito, tamanho do prêmio pelo risco, inflação e expectativa de inflação e a volatilidade do mercado financeiro. Adicionalmente, o foco no mercado também é relevante pois se refere à metodologia empregada pela empresa compradora para avaliar as oportunidades. Na década de 60, por exemplo, as empresas 
norte-americanas eram focadas no demonstrativo de resultados e nos lucros por ação de uma empresa a ser adquirida. Na década seguinte, o foco era o balanço patrimonial, enquanto que na década de 80 , a preocupação principal era o fluxo de caixa e o nível de alavancagem.

Tanto os fatores relacionados aos ativos como ao financiamento são resultados de elementos fundamentais do ciclo do negócio que são os elementos macroeconômicos. Estas forças macroeconômicas incluem a política fiscal e monetária, aspectos políticos e legais, regimes regulatórios, forças culturais e mudanças tecnológicas. Mudanças nestes fatores econômicos influenciam o mercado e o ciclo do negócio o que estimula ou retarda as forças que conduzem à fusão ou aquisição.

De uma maneira geral, pode-se ver o mercado para controle corporativo como um puro exercício de arbitragem: os indivíduos procurando lucros provenientes das imperfeições na utilização dos ativos ou da precificação incorreta das obrigações da corporação de forma a beneficiá-la. As ações que estes indivíduos podem tomar diante das imperfeições de mercado, reais ou imaginárias, podem variar. Eles podem desde simplesmente especular com as ações da empresa, acreditando que o mercado irá corrigir o preço, como lançar um take over hostil contra toda a empresa. A diferença principal entre estas duas estratégicas de investimento é o controle corporativo.

O investidor que deseja obter lucro através da reestruturação da empresa comprada não deseja aguardar o mercado reavaliar as ações da empresa e por isto, requer o controle da empresa. Por outro lado, o especulador que realizou a sua posição na empresa em questão, que pode tentar obter a mudança na avaliação da mesma através do fornecimento de informações para o mercado, não se preocupa com a alteração direta do balanço patrimonial e, portanto, não necessita do controle. 
A obtenção do controle, ou seja, a obtenção da maioria dos votos no conselho de administração, permite ao investidor acesso ao ativo do portfolio da empresa e desta forma fornece a oportunidade de arbitragem no lado esquerdo do balanço patrimonial. O controle também permite acesso ao lado direito do balanço e a oportunidade de reconfigurar a estrutura de capital da empresa. Como resultado, os indivíduos e as empresas engajados em fusões e aquisições são "arbitradores" mas não como os especuladores de ativos financeiros. A empresa que está realizando a aquisição decide reconfigurar pelo menos um dos lados do balanço patrimonial da empresa comprada e paga um prêmio por este privilégio enquanto que o especulador financeiro não detém esta possibilidade de modificação nas empresas onde ele possui ações. A arbitragem é uma reação às imperfeições tanto no equilíbrio de mercado como no uso das informações e funciona para manter o sistema honesto e eficiente.

\section{II.7.4. ALIANÇA ESTRATÉGICA: ALTERNATIVA ÀS FUSÕES E AQUISIÇÕES}

Uma alternativa à estratégia de diversificar o portfolio de produtos e serviços através de fusões e aquisições é a realização de alianças entre empresas. De acordo com o Chief Executive Officer (CEO) da General Electric, Jack Welch "If you think you can go it alone in today's global economy, you are highly mistaken" (HARBISON e PEKAR, 1999).

No estudo realizado por HARBISON e PEKAR (op. cit.), estima-se que foram realizadas mais de 20.000 alianças em todo o mundo entre os anos de 1996 e 1998. O resultado destas alianças foi um crescimento no faturamento de quase duas vezes se comparado ao início da década de 90 representando $21 \%$ do faturamento das 1.000 maiores empresas norte-americanas em 1997. O estudo também apresenta duas conclusões pertinentes: 
- por aproximadamente 10 anos, alianças estratégicas entre as 2000 maiores empresas mundiais apresentaram um retorno médio anual sobre o investimento (ROI) de $17 \%$, sendo este número $50 \%$ maior que o ROI das atividades que não participaram de aliança

- a porcentagem de faturamento anual que as 1.000 maiores empresas dos EUA obtiveram com alianças saltou de menos de 2\% em 1980 para 19\% em 1996 e espera-se chegar a 35\% em 2002.

Além das desvantagens operacionais e financeiras apresentadas por vários estudos nas situações de fusões e aquisições, existe ainda a questão da diferença entre as culturas organizacionais das empresas envolvidas. Por esta razão, a decisão estratégica de se realizar alianças mostra-se uma oportunidade a ser considerada.

\section{II.7.5. CORRENTES TEÓRICAS SOBRE FUSÕES E AQUISIÇÕES}

Para WESTON (1994), as diferentes teorias que discutem a eficiência das fusões e aquisições podem ser agrupadas em cinco categorias: (1) eficiência; (2) informação; (3) problemas de agência; (4) poder de mercado; e (5) impostos.

O grupo que reúne a teoria da eficiência hipotetiza que a fusão pode tanto melhorar o desempenho de uma empresa como produzir uma empresa mais eficiente que antes da aquisição através de algum tipo de sinergia. O movimento de fusões e aquisições na década de 60 exagerou nos benefícios da sinergia claramente observados através de um efeito conhecido como "2+2=5". A teoria dizia que a nova empresa formada com a aquisição poderia produzir resultados bem melhores que suas partes separadamente. Embora as expectativas fossem exageradas, havia realmente ganhos que poderiam ser de ordem operacionais, economias de escala tanto em fusões horizontais como 
verticais, financeiras, redução no custo de capital, ou realinhamento estratégico.

A segunda razão possível para fusões é a hipótese da informação que se refere à reavaliação das ações em propriedade da empresa devido as novas informações que são geradas durante as negociações das fusões.

As teorias agrupadas dentro dos problemas de agência sugerem que a atividade de fusão é um método para lidar com estes problemas. Contudo, uma variante da Teoria de Agência é a Manageralism Theory que sugere que os problemas de agência não podem ser resolvidos e que a atividade de fusão manifesta a ineficiência através de investimentos externos realizados pelos executivos.

De acordo com o último grupo de teorias, poder de mercado, se quatro ou um pouco mais de empresas obtêm um percentual substancial de vendas de uma indústria, elas reconhecem o impacto de suas ações e políticas entre si. Este reconhecimento de interdependência leva à consideração das ações assim como as reações para mudanças de políticas que direcionam a um conluio tácito Como resultado, os preços e lucros destas empresas contêm elementos de monopólio. Assim sendo, se economias esperadas pela fusão não ocorrerem, argumentase que o aumento na concentração foi motivado pelos ganhos do monopólio.

II.8. EVOLUÇÃo DO SETOR DE TELECOMUNICAÇÕES EM DIREÇÃo ÀS FUSÕES E AQUISIÇÕES

O cenário tecnológico internacional modificou-se profundamente durante a década de 1980. As indústrias com tecnologias já amadurecidas nas duas décadas anteriores foram atualizadas por inovações tecnológicas e incrementais. Concomitantemente, novas indústrias surgiram e 
tornaram-se o pilar de sustentação do desenvolvimento tecnológico e da produção e do comércio internacionais. Como resultado, surgiram novas tecnologias e paradigmas industriais que eram compatíveis com as atividades anteriores de administração da produção e outras totalmente diferentes, exigindo uma completa reformulação nos procedimentos e formas de pensamento (CHESNAY, 1990 In COUTINHO, CASSIOLATO e SILVA, 1995).

Como parte deste cenário de transformações, encontra-se um pequeno número de áreas caracterizadas por um intenso dinamismo tecnológico, abrangendo avanços na microeletrônica, melhorias em velhos materiais e desenvolvimento de novos materiais. Esse núcleo de inovações desdobra-se em outras, revelando a diversidade e a intensidade do processo de mutação tecnológica em curso em todo o setor industrial.

Esta diversidade envolve mudanças centradas nos processos produtivos, conduzindo à produtividade devido à eficiência com que se utiliza o capital, trabalho, energia e materiais e também centradas nos produtos que vêm apresentando reduções de tempo entre as descontinuidades tecnológicas, implicando na redução do ciclo de vida de novos produtos e ampliando a diversidade de pequenas diferenciações de produtos.

Segundo COUTINHO (1995), a importância e os impactos das tecnologias de base eletrônica são amplamente reconhecidos na intensificação do processo de mutação tecnológica e acrescenta três outras características. Primeiramente, a incorporação de produtos eletrônicos em outros produtos, processos e sistemas organizacionais através do envolvimento direto do usuário no desenvolvimento tecnológico que requer uma capacitação tecnológica no desenvolvimento e no projeto de hardware e software adequados ao ambiente de utilização. Segundo, a difusão da tecnologia eletrônica é 
acelerada pela presença de usuários avançados que não servem apenas de demonstradores para outras empresas, mas também contribuem para o desenvolvimento de inovações que aumentam a eficácia das tecnologias no contexto específico de sua utilização. Finalmente, a tecnologia eletrônica é um poderoso instrumento para gerar inovações e mudança tecnológica como é o caso do software CAD (Conputer Aided Design), que permite mudanças mais rápidas e freqüentes no design de produtos e processos e a exploração mais intensiva e extensiva de diferentes opções de design.

As transformações econômicas e sociais advindas da revolução da microeletrônica não se resumem ao crescimento das novas indústrias ligadas ao complexo eletrônico mas envolve também a transformação dos demais setores industriais e das atividades de serviços. A Tabela 05 apresenta de maneira sintética as principais mudanças no complexo eletrônico associadas ao novo paradigma técnico-econômico desde o final dos anos 40 (FREEMAN e SOETE, 1993 In COUTINHO, 1995) 


\begin{tabular}{|c|c|c|}
\hline Anos & & diante \\
\hline $\begin{array}{l}\text { Uso de válvulas. Predomínio de } \\
\text { aplicações militares. Potencial } \\
\text { futuro subestimado. Melhorias } \\
\text { tecnológicas em arquitetura, } \\
\text { memória e periféricos dão início } \\
\text { a mercado comercial nos anos } \\
50 \text {. Melhorias em desempenho } \\
\text { e confiabilidade pelo uso de } \\
\text { transistores e circuitos } \\
\text { integrados. Mainframes } \\
\text { dominam processamento de } \\
\text { dados em grandes empresas - } \\
\text { minicomputadores nos anos } 60 \text {. }\end{array}$ & $\begin{array}{l}\text { A partir de 1971, o } \\
\text { microprocessador leva à } \\
\text { difusão de computadores } \\
\text { pessoais pequenos e } \\
\text { baratos, mudando } \\
\text { radicalmente a indústria. } \\
\text { Mainframes } \\
\text { departamentos de } \\
\text { processamento de dados } \\
\text { centralizados perdem } \\
\text { espaço gradativamente, } \\
\text { enquanto os PC's e } \\
\text { workstations ganham fatias } \\
\text { crescentes de mercado. }\end{array}$ & $\begin{array}{l}\text { Disponibilidade universal } \\
\text { de PC's e de } \\
\text { computadores portáteis e } \\
\text { de bolso ligados à rede. } \\
\text { Uso de computadores } \\
\text { amplamente difundidos. } \\
\text { Supercomputadores e } \\
\text { processamento paralelo } \\
\text { para P\&D e outras } \\
\text { aplicações (como banco } \\
\text { de dados) que exijam } \\
\text { vasta capacidade de } \\
\text { memória. }\end{array}$ \\
\hline $\begin{array}{l}\text { b.) Software } \\
\text { Primeiras linguagens de } \\
\text { programação nos anos } 50 . \\
\text { Empresas de hardware } \\
\text { desenvolvem e fornecem } \\
\text { software cada uma com seu } \\
\text { padrão. Com a multiplicação de } \\
\text { aplicações, usuários científicos } \\
\text { desenvolvem software. usuários } \\
\text { com grandes departamentos de } \\
\text { processamento de dados } \\
\text { desenvolvem software } \\
\text { conjuntamente com produtores } \\
\text { de hardware. Emergência de } \\
\text { empresas independentes de } \\
\text { software dando consultoria e } \\
\text { suporte a usuários. }\end{array}$ & $\begin{array}{l}\text { Rápido crescimento do } \\
\text { setor de software, } \\
\text { especialmente nos EUA. } \\
\text { Pacotes de software } \\
\text { userfriendly facilitam a } \\
\text { difusão de computadores, } \\
\text { especialmente para PME's; } \\
\text { software "customizado" e } \\
\text { modificado também cresce } \\
\text { rapidamente. Movimento } \\
\text { em direção a "sistemas } \\
\text { abertos" no final dos anos } \\
80 \text { facilita a conexão e } \\
\text { networking. Falta de } \\
\text { pessoal especializado é } \\
\text { grande nos anos } 70 \text { e } 80 \text {, } \\
\text { sendo menor nos anos } 90 .\end{array}$ & $\begin{array}{l}\text { Redução da necessidade } \\
\text { de pessoal em software } \\
\text { devido a: pacotes padrão; } \\
\text { automação; redução no } \\
\text { suporte de mainframes; } \\
\text { aumento das capacitações } \\
\text { dos usuários. De outro } \\
\text { lado, surgem novas } \\
\text { demandas de software a } \\
\text { partir de: processamento } \\
\text { paralelo; multimídia; } \\
\text { realidade virtual e expert } \\
\text { systems; mudanças nas } \\
\text { configurações visando a } \\
\text { contínuas mudanças } \\
\text { organizacionais } \\
\text { técnicas. } \\
\text { renovada para projeto e } \\
\text { manutenção de software. }\end{array}$ \\
\hline
\end{tabular}




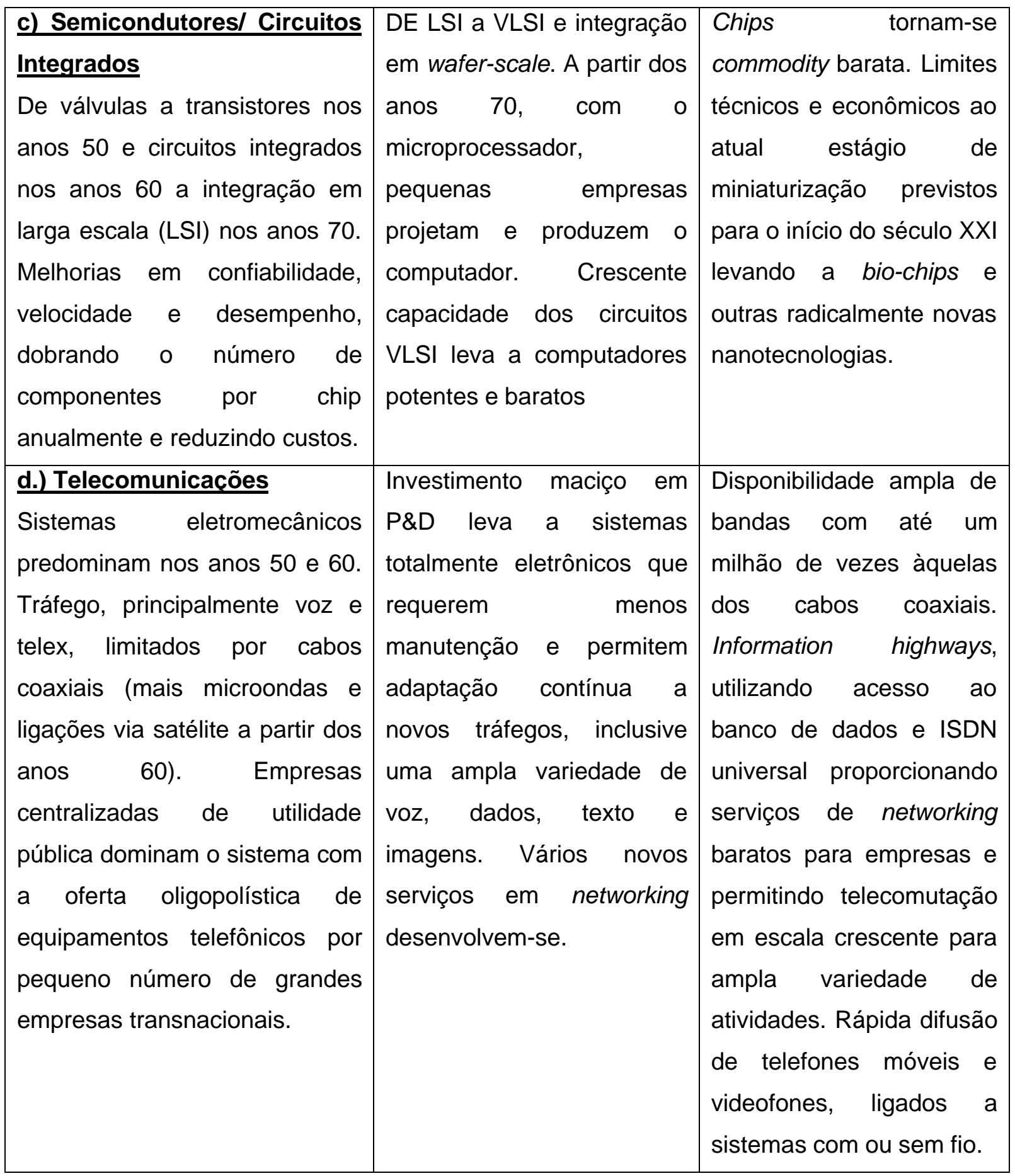

Fonte: Coutinho et al., 1995

TABELA 5 - PRINCIPAIS MUDANÇAS NO COMPLEXO ELETRÔNICO ASSOCIADAS AO NOVO PARADIGMA TECNO-ECONÔMICO DO FINAL DOS ANOS 40 AOS ANOS 90

Na década de 80, uma característica marcante do complexo foi a rápida sucessão de geração de circuitos integrados. O número de componentes contidos num processador mais do que dobrou ano a ano, 
alcançando alguns milhões e ainda continua crescendo. Conseqüentemente, as empresas que incorporam componentes microeletrônicos foram obrigadas a realizar freqüentes mudanças nos projetos e na composição de produtos. A capacidade de realizar essas mudanças tornou-se uma poderosa vantagem competitiva para empresas do complexo eletrônico. Velocidade de processamento, capacidade de armazenamento, flexibilidade e comunicação em rede emergiram, portanto, ao longo dos anos 80, como características fortemente inter-relacionadas do novo paradigma técnico-econômico.

Como conseqüência, os anos 90 caracterizaram-se pela convergência entre as tecnologias de computação e comunicações. Embora facilmente identificável em termos técnicos, essa convergência revela-se como um processo ainda carregado de problemas e incertezas, pois envolve diferentes instituições e regimes regulatórios. As empresas telefônicas de utilidade pública e seus fornecedores de equipamentos desenvolveram-se dentro de uma cultura e um sistema de regulações totalmente diferentes das novas empresas de computação e software com as quais eles devem agora competir e colaborar. A cultura, as tradições e o comportamento de ambos os tipos de empresas são, por sua vez, totalmente diferentes das características dos chamados usuários, tanto no setor manufatureiro quanto em outras atividades de serviços, com os quais elas agora contemplam alianças estratégicas, parceiras e fusões. As fronteiras entre as atividades de todas elas estão sendo totalmente redesenhadas num momento em que mudanças ainda mais radicais despontam no horizonte.

Embora ainda não esteja bem definida ou apresente um entendimento do que vem a ser o processo de globalização, COUTINHO (1995) define este processo através de três fenômenos distintos: as relações econômicas tradicionais entre nações resultantes do comércio 
internacional; as atividades de empresas multinacionais em mercados extrafronteiras; e os mercados financeiros e monetários propriamente globais que surgiram nos anos 60 e destacaram-se na década de 70 e 80.

As novas dimensões da globalização relacionam-se à emergência de um sistema mundial de interligações de redes privadas entre os principais bancos e empresas industriais e de serviços instalando-se redes de informações mundiais internas que permitem a empresa ligar produção e marketing ao redor do mundo, estimulando ampla gama de alianças e ligações e também estratégias envolvendo novos tipos de interações com fornecedores, clientes e concorrentes.

O setor de telecomunicações passa a desempenhar um papel-chave no processo de geração e difusão das novas tecnologias de base microeletrônicas, dado o seu papel integrador dos diversos sistemas. De modo geral, as empresas industriais e de serviços passam por uma série de etapas no uso de telecomunicações: primeiramente, é utilizada para automatizar e reorganizar as funções básicas do negócio, em seguida, torna-se uma força produtiva e veículo de maior reorganização de estratégias produtivas; na terceira etapa, as telecomunicações tornam-se um componente principal na relação da empresa com 0 mercado através do monitoramento da cadeia de suprimento e demanda. Finalmente, as telecomunicações tornam-se uma força de integração e de relação através de redes entre empresas, seus fornecedores e clientes (MANSELL e MORGAN, 1990).

É correto, portanto, considerar as telecomunicações como elemento catalisador no processo de difusão da microeletrônica para além das fronteiras da empresa individual. A convergência atual entre as tecnologias de telecomunicações e de computação, função principalmente da tendência à digitalização, permite, do ponto de vista 
tecnológico, a ampliação dos movimentos que já ocorriam no âmbito da firma para a corporação e para a economia como um todo.

Desde a década de 70, o setor de telecomunicações nos países industrializados tem atravessado um período de extraordinárias transformações em três níveis básicos: na área tecnológica, no ambiente concorrencial de empresas e países na esfera de regulamentação institucional dos serviços (COUTINHO, 1995). Em paralelo às mudanças ocorridas na oferta dos serviços de telecomunicações, verificam-se também alterações na demanda por esses serviços, com ampliação significativa da área não-residencial colaborando para com a competitividade e produtividade nas empresas. Este processo de transformações das telecomunicações ocorre de forma diferenciada e engendra importantes mudanças políticoinstitucionais. A partir de meados da década de 70 , há um crescente questionamento quanto ao desempenho e à eficiência dos tradicionais operadores de serviços de telecomunicações, impulsionado pelas políticas de Ronald Reagan nos Estados Unidos e Margareth Thatcher na Inglaterra. A existência de inegáveis economias de escopo propiciadas pelas novas tecnologias de informação, aliada à redução de custos de transmissão e processamento de informações, permite o surgimento de novos ofertantes, geralmente interessados em explorar serviços específicos (nichos de mercado) ou mesmo rotas mais lucrativas dos serviços tradicionais (interurbanos), impondo assim a necessidade de rever o quadro regulamentar e redefinir as áreas de monopólio natural.

No âmbito internacional observam-se diferentes estratégias de alteração da regulamentação das telecomunicações. Os Estados Unidos tendeu, desde o final da década de 50, a acentuar a concorrência entre os diferentes segmentos, produzindo grande fragmentação da rede de 
telecomunicações. Por sua vez, a Europa continental, representada principalmente pela França e Alemanha, tende a enfatizar a concorrência apenas nos níveis superiores (serviços de maior valor adicionado), preservando o monopólio público da rede básica, com o intuito de acelerar a digitalização e universalização da nova infraestrutura. Nos países anglo-saxônicos (e no Japão) houve um processo não só de maior desregulamentação como também de privatização (tanto a transferência da propriedade como introdução de novos serviços privados) do operador público de telecomunicações.

Esta revolução no setor de telecomunicações, notadamente nas operadoras de telecomunicações, produziu efeitos nos seus fornecedores conduzindo-os ao desenvolvimento de novas tecnologias. A diversificação estratégica ocorrida na década de 80 e que se mantém na década de 90 vem sendo motivada pelo desejo das empresas em participarem do crescimento industrial em áreas emergentes e tecnologicamente focadas. Diferentemente da diversificação que ocorreu na década de 60 e que foi conduzida por motivos financeiros, nestas duas últimas décadas o propulsor para esta atividade tem sido a orientação para a indústria/mercado. As grandes empresas com seus grandes volumes de recursos disponíveis têm buscado adquirir posições nas indústrias em crescimento onde a competição é ditada não pelas forças financeiras ou operacionais mas sim por fatores tecnológicos. Em muitos casos, a única possibilidade para as grandes empresas entrarem neste mercado é através de aquisições ou fusões, contrariando os estudos que indicam o retorno à especialização.

\section{II.9. MAXIMIZAÇÃO DA RIQUEZA COMO FUNÇÃO-OBJETIVO}

Para DAMODARAN (1997), nenhuma disciplina pode se desenvolver ao longo do tempo sem unificar a função-objetivo. O crescimento da teoria 
de finanças corporativas pode ser traçado através da escolha desta função e o desenvolvimento de modelos ao seu redor. O objetivo convencional na teoria de finanças corporativas é maximizar o valor da firma. Conseqüentemente, qualquer decisão (investimento, financiamento ou dividendo) que aumente o valor da firma é considerada como uma boa opção, e a decisão que reduz o valor da firma é considerada uma má opção. Muitas das discordâncias entre pesquisadores, acadêmicos e praticantes podem ser identificadas através das diferentes visões sobre a correta função-objetivo da empresa. Por exemplo, alguns acreditam que a empresa deveria ter múltiplos objetivos devido aos vários interesses (acionistas, empregados, clientes) enquanto que outros defendem que a firma deve ter um foco que refere-se à simplicidade e clareza do objetivo tal como participação no mercado ou rentabilidade.

O clássico objetivo da maximização da riqueza (do acionista ou da firma) parece indiscutível até considerar-se a complexidade das modernas corporações onde os proprietários (acionistas) contratam executivos para tomar decisões e toma recursos emprestados dos credores que não podem monitorar perfeitamente como estes recursos serão utilizados. Os incentivos e os objetivos destes três atores na empresa são geralmente diferentes, resultando num conflito entre eles. Os executivos podem desejar tomar decisões que atendam aos seus interesses, desconsiderando os interesses dos acionistas; ou então atendendo os interesses dos acionistas, podem desagradar aos credores. Este problema pode se acentuar se considerar-se também os interesses dos funcionários empregados na firma, os clientes e a sociedade. 


\section{II.10. MÉTODOS DE AVALIAÇÃO}

Para GITMAN (1997), o valor de qualquer ativo depende do fluxo de caixa que se espera que ele gere durante o período considerado. Para ter valor, um ativo não fornecer um fluxo de caixa anual; pode fornecer um fluxo de caixa intermitente, ou, então, um fluxo de caixa único durante o período. Resumidamente, o valor de qualquer ativo pode ser calculado através o valor presente de todos os futuros fluxos de caixa esperados, durante um período relevante de tempo.

O risco descreve a possibilidade de que um resultado esperado não seja realizado. O nível de risco associado com um dado fluxo de caixa pode afetar significativamente seu valor. Em geral, quanto maior o risco de um fluxo de caixa, menor será o seu valor. Em termos de valor presente, um risco maior pode ser incorporado em uma análise, pelo uso de um retorno exigido ou taxa de desconto maiores. No processo de avaliação, o retorno exigido é usado para incorporar o risco na análise.

O orçamento de capital representa o processo de planejar os investimentos que produzem retornos ao longo de um período. Muito embora o critério de orçamento de capital seja geralmente discutido em relação a investimentos em ativos fixos, os conceitos são igualmente aplicáveis a investimentos em ativos circulantes e também fusões e aquisições.

As decisões de investimentos e suas avaliações através da análise do orçamento de capital são importantes por algumas razões:

1. as conseqüências das decisões continuam para um número de anos fazendo com que a flexibilidade para o futuro seja reduzida;

2. o orçamento de capital requer planejamento efetivo, incluindo uma acuracidade na previsão de vendas para assegurar o momento propício para aquisição do ativo; 
3. dado que a expansão de ativos envolve diferentes aspectos tais como legais e financeiros, o financiamento requerido deve ser providenciado antecipadamente;

4. uma vez que o volume financeiro a ser investido é alto, o sucesso ou fracasso de uma empresa pode resultar no investimento excessivo ou insuficiente, ou demora na substituição de ativos obsoletos.

Vários métodos de avaliação de investimentos têm sido desenvolvido. Para WESTON CHUNG e HOAG (1990), o método do Valor Presente Líquido é considerado superior a todos os outros métodos de avaliação e classificação de propostas de investimentos.

O método do Valor Presente Líquido é o valor presente de todos os fluxos de caixa futuros descontado pela custo de capital menos o custo do investimento também descontado pelo custo de capital. Seu maior concorrente é o método da Taxa Interna de Retorno que representa a taxa de desconto que iguala todos os fluxos de caixa a zero.

A principal diferença entre estes dois métodos é que o método do Valor Presente Líquido assume reinvestimentos a taxa do custo de capital enquanto que o método da Taxa Interna de Retorno assume o reinvestimento a sua própria taxa. O primeiro método apresenta como vantagem sobre o segundo o fato de mostrar o quanto é adicionado de valor a empresa para cada investimento considerado.

As variáveis críticas na determinação do valor presente líquido e da taxa interna de retorno são o fluxo de caixa e o custo de capital. Quando a avaliação de investimento é feita ao nível da empresa, deve-se adicionar todos os projetos de investimento assumidos. A análise, desta forma, utiliza as demonstrações de financeiras da empresa como 0 demonstrativo de resultado e o balanço patrimonial. Ambos podem ser utilizados para explicar os elementos contidos no fluxo de caixa anualizados a serem capitalizados. A soma de cada fluxo de caixa anual 
menos os investimentos requeridos, devidamente descontados, conduzem então ao valor da empresa.

A fonte intelectual dos modernos modelos de avaliação é o artigo clássico de MILLER e MODIGLIANI (1961). Eles demonstraram que o mesmo modelo básico de avaliação pode ser derivado utilizando-se 4 abordagens diferentes: fluxo de caixa descontado, dividendos, lucro e oportunidades futuras de investimentos. As duas últimas são equivalentes ao modelo de fluxo de caixa livre.

A vantagem da formulação de Miller e Modigliani refere-se as duas conclusões que se pode tirar: (1) relacionamento entre lucratividade e custo de capital; (2) ênfase no fato de cada empresa ser uma empresa sem crescimento ao menos que tenha investimentos favoráveis.

\section{II.11. MEDIDAS DE VALOR}

Um modelo de medida de valor no Brasil é o GVA- $50^{\circledR}$ que lista as 50 empresas não financeiras com as ações mais líquidas do IBX - Índice Brasil, classificando-as em ordem decrescente pelo retorno total ao acionista. $O$ objetivo deste estudo é divulgar os resultados e o conceito de Geração de Valor ao Acionista (GVA). Esta medida de valor não depende de dados contábeis enquanto que o modelo proposto por BERGER e OFEK baseia-se nos dados contábeis.

A seguir, apresenta-se outras formas de medidas de valor.

\section{II.11.1. FLUXO DE CAIXA}

COPPELAND et.all (1990) destaca um capítulo no seu livro sobre a importância do fluxo de caixa como medida de valor da empresa. Destaca ainda um trecho de um editorial publicado pelo Wall Street Journal em 1 de outubro de 1974, que lamenta o foco exagerado dado pelos executivos no lucro por ações (E/S) como um indicador de valor: 
A lot of executives apparently believe that if they can figure out a way to boost reported earnings, their stock prices will go up even if the higher earnings do not represent any underlying economic change. In other words, the executives think they are smart and the market is dumb... The market is smart. Apparently the dumb is the corporate executive caught up in the earnings-per-share mystique.

Um dos motivos dos executivos idolatrarem o indicador lucro por ações segundo Coppeland é a simplicidade de se calcular com o intuito de se responder a várias questões. Porém, este indicador ignora os efeitos peculiares da contabilidade, podendo conduzir a decisão para a opção que destrói valor no longo prazo.

O lucro contábil é útil para precificação da empresa somente quando o lucro é uma boa aproximação para o fluxo de caixa esperado de longo prazo da empresa pois nem todas as empresa geram o mesmo fluxo de caixa para cada unidade monetária obtida.

Explícita ou implicitamente, todas as decisões dos executivos são baseadas em algum modelo de precificação com o intuito de tomar ações que aumentem o valor das ações da empresa. Coppeland indica dois grupos de modelos que competem entre si: um modelo contábil e um modelo econômico.

No modelo contábil, o importante é o lucro contábil da empresa. Valor é simplesmente o lucro vezes algum outro múltiplo (preço por lucro, $\mathrm{P} / \mathrm{E}$ ). Neste modelo extremo, apenas o ganho deste e do próximo ano importam. Alguns modelos chegam até a trazer o fluxo de caixa a valor presente. Este modelo não considera o investimento necessário para gerar o lucro ou o seu tempo de duração.

No modelo econômico como o fluxo de caixa descontado, por exemplo, o valor da empresa é o fluxo de caixa futuro esperado descontado a 
uma taxa que reflete o risco do negócio. Este modelo considera a necessidade de investimentos ao longo do tempo.

Um estudo feito por Coppeland mostra a fraca correlação entre o crescimento do lucro por ação e preço por ação $\left(R^{2}=0,024\right)$ levando-o a concluir que o crescimento do lucro é um indicador muito fraco de criação de valor muito embora outros pesquisadores argumentam que algumas medidas de retorno sobre o capital investido são o melhor indicador de criação de valor. Esta argumentação é consistente com o modelo econômico que diz que o valor é criado quando o ganho do capital investido retorna acima do seu custo. Porém, não existe evidências que mostram uma forte correlação entre retorno contábil e valor da empresa pois é impossível capturar a essência da complexidade do fluxo de caixa em um número apenas.

Coppeland conclui com a parte final do editorial: "To us the lesson is clear: If the manager keeps his eye on the long-run health of the enterprise, the stock price will take care of itself'. Portanto, se a empresa se preocupa com a sua saúde financeira de longo prazo, ela deve-se preocupar com a maximização do valor das ações através da análise do fluxo de caixa descontado e não do lucro por ações. O fluxo de caixa descontado é capaz de capturar todos os elementos que afetam o valor da empresa de uma maneira compreensiva.

\section{II.11.2. LUCRO ECONÔMICO E LUCRO CONTÁBIL}

De acordo com PETERSON e PETERSON (2000), muitas corporações americanas tais como The Coca-Cola Company, Briggs \& Stratton Corporation e AT\&T Corporation, estão adotando um método relativamente novo de avaliação, e premiando o desempenho da administração baseado na idéia de compensá-la pelo lucro econômico ao invés do lucro contábil. Lucro econômico é basicamente a diferença 
entre receitas e custos, onde estes custos incluem não somente despesas, mas também o custo do capital. E apesar da aplicação do lucro econômico ser relativamente nova na medida do desempenho, este conceito existe desde o final do século XIX (Marshal, 1.890). O que esta ênfase recente no lucro econômico tem feito é focalizar a atenção primeiro no lucro contábil e em seguida no custo de capital.

Duas distinções importantes devem ser feitas entre lucro econômico e lucro contábil. A primeira distinção refere-se ao custo do capital. Lucro contábil é a diferença entre receitas e custos, com base no fato de que a apresentação destes itens está de acordo com os princípios contábeis normalmente aceitos. Lucro econômico é também a diferença entre receitas e custos, porém, ao contrário do que ocorre na determinação do lucro contábil, no lucro econômico o custo do capital está incluído naqueles custos.

A segunda distinção entre lucro econômico e lucro contábil relaciona-se com os princípios de reconhecimento de receitas e despesas. Lucros contábeis, na maior parte das vezes, são representados usando-se regime de competência, enquanto que lucros econômicos refletem uma contabilidade em regime de caixa. Entretanto, como os dados são relatados nos relatórios financeiros somente em termos de contabilidade por competência, os analistas, ao calcularem o lucro econômico, devem primeiro iniciar com lucros contábeis e, depois, ajustar os dados para o regime de caixa.

Ao contrário do lucro contábil, o lucro econômico (se medido corretamente) não pode ser manipulado pela administração, mediante a escolha de métodos contábeis. Além disto, baseando a compensação dos gestores no lucro econômico, ao invés do lucro contábil, encoraja a visão de longo prazo no processo decisório. Por conseguinte, a 
premiação da administração baseada no lucro econômico é uma idéia atraente.

\section{II.11.3. ECONOMIC VALUE ADDED E MARKET VALUE ADDED}

O conceito de Economic Value Added (EVA), apesar de ter se popularizado nos últimos anos, na verdade não é uma novidade nos meios acadêmicos e empresarial. David Ricardo, em seus tratados de economia, já em 1.823 tratava da riqueza da empresa dessa forma, considerando o valor econômico agregado.

$\mathrm{Na}$ introdução da obra de EHRBAR (1998), Joel M. Stern credita a origem teórica do EVA ao modelo econômico de valor da firma desenvolvida por Merton H. Miller e Franco Modigliani e explica o porquê do conceito ter sido popularizado quase 200 anos depois.

Nos trabalhos de Merton e Miller em 1958, 1960 e 1961, pela primeira vez, a teoria básica de microeconomia foi aplicada a finanças corporativas e mostrada o porquê do modelo econômico da firma, não o contábil, era preferível. Em resumo, eles mostraram que:

O fator fundamental de valor é o resultado econômico e a taxa de retorno exigida era diretamente proporcional ao risco

O valor de mercado da firma é o resultado do comportamento racional do investidor

O risco da estrutura de capital pode ser diferenciado independentemente dos ativos da firma ou do risco do negócio

Em termos simples, o modelo de MM mostrou porque o fluxo de caixa descontado como um processo e o valor presente líquido como uma medida reflete como o mercado funciona no mundo real.

O desenvolvimento do EVA também deve muito ao trabalho em teoria de agência desenvolvido por Michael C. Jensen e William H. Meckling. A crença principal era de que os executivos poderiam tentar colocar seus 
interesses pessoais acima dos interesses dos acionistas e que os acionistas e credores deveriam incorrer em custos de monitoramento para evitar esta situação.

As teorias de finanças, por intermédio de indicadores tais como valor presente líquido (VPL), índice de lucratividade (IL), taxa interna de rentabilidade (TIR), payback ajustado etc., também representam o valor econômico agregado. O VPL, por exemplo, é o valor absoluto (em dinheiro) que sobra após o desconto dos valores por uma determinada taxa de desconto, a taxa mínima de atratividade (TMA); ou seja, é o valor agregado.

Conforme cita KASSAI et.all (2000), no Brasil, com a Lei no. 9.249/95, a contabilidade financeira passou a reconhecer a figura dos juros sobre 0 capital próprio. As empresas têm, desde então, a possibilidade de deduzir do lucro uma despesa relativa a remuneração do capital dos acionistas, calculada a partir da taxa de juros de longo prazo (TJLP) sobre o montante do patrimônio líquido.

Se o VPL de um projeto é negativo, significa que o mesmo não agrega valor econômico. Da mesma forma, se o resultado contábil, apurado após a dedução da despesa de juros sobre o capital próprio, for um prejuízo, a empresa está destruindo valor econômico.

O valor econômico agregado, ou EVA, é, pois, o valor que a empresa agrega após remunerar todos os recursos investidos, quer sejam financiados pelo custo de capital de terceiros ou pelo custo de capital próprio. Este conceito tem sido utilizado também como ferramenta de gestão baseada em valor, onde o foco não se restringe apenas à empresa como um todo, mas direcionado a todas as partes. A análise o que agrega ou não valor passa a dar suporte ao processo decisório.

Críticas têm sido feitas no sentido de que o EVA é uma medida dirigida ao passado, pois é calculado sobre as informações contábeis oriundas 
de transações já ocorridas. Assim a Stern \& Stewart registrou uma outra marca denominada Market Value Added (MVA), ou valor de mercado agregado, que avalia o valor econômico da empresa como um todo e em relação ao potencial de resultados futuros.

O MVA é interpretado como a diferença entre o valor da empresa menos o valor de seus investimentos, a preços de mercado. Ele representa o valor econômico da empresa em relação às suas expectativas de lucros futuros enquanto que o EVA tem o mesmo entendimento voltado para o passado.

\section{II.11.4. MEDIDAS DE DESEMPENHO UTILIZADAS NA AVALIAÇÃO}

Medir se a administração acrescentou ou diminui o valor de uma empresa durante um determinado período é difícil, porque este valor pode ser afetado por diversos fatores. Atualmente, algumas técnicas de medição de desempenho defendidas, tais como o EVA e o MVA da Stern, Stewart \& Company, são baseados em princípios de avaliação, porém existe uma importante distinção entre avaliação e medição de desempenho: avaliação está ligada a previsões, e medidas de desempenho estão relacionadas a resultados reais.

Índices financeiros são tradicionalmente usados para avaliar a performance das empresas. Estas medidas incluem os índices de retorno sobre investimentos e a relação de valor de mercado/ valor contábil (expresso pelo q de Tobin).

O índice retorno sobre investimento compara o benefício de decisões (representado pelo numerador) com os recursos que afetam aqueles benefícios (representado no denominador. Para avaliar de que maneira a empresa usa seus ativos em suas operações, o basic earning power ratio, que é o quociente entre lucro antes de juros e impostos (lucro operacional) e os ativos totais, utiliza-se a fórmula: 


$$
\text { Basic earning power ratio }=\frac{\text { Lucro antes de juros e impostos }}{\text { Ativos totais }}
$$

Pelo fato deste índice utilizar os lucros das operações, ele não considera como estas operações foram financiadas; isto quer dizer que lucros antes de juros e impostos estão disponíveis para pagamento a credores e acionistas.

Um outro índice de retorno sobre investimento, retorno sobre ativos, utiliza o lucro líquido (lucros operacionais menos juros e impostos) em relação aos ativos totais:

$$
\text { Retorno sobre ativo }=\frac{\text { Lucro Líquido }}{\text { Ativos totais }}
$$

Este índice demonstra o retorno disponível para os acionistas gerado pelo investimento de capital de credores e dos acionistas.

Um investidor pode não estar interessado no retorno que a empresa obtém de seu investimento total (recursos providos pelos credores e pelos acionistas), porém, ele pode estar interessado no retorno que a empresa ganha sobre o patrimônio líquido. Retorno sobre patrimônio líquido é o índice calculado dividindo-se o lucro líquido que os acionistas recebem por seu patrimônio em ações:

$$
\text { Retorno sobre Patrimônio Líquido }=\frac{\text { Lucro Líquido }}{\text { Valor Contábil do Patrimônio Líquido }}
$$


Segundo PETERSON e PETERSON (2000), índices de retorno são utilizados normalmente de duas maneiras. Primeiro, índices de retorno são freqüentemente comparados ao longo do tempo para uma dada empresa, se for a tendência, ao invés do retorno real para um período particular que indique o desempenho. Segundo, ao invés de retorno são normalmente comparados entre empresas ou comparados a um padrão, tal como o retorno médio de um setor ou um retorno para os líderes do setor.

Uma vantagem de se usar índices para a avaliação de desempenho de uma empresa é a facilidade de cálculo. Todas as informações necessárias para os cálculos estão disponíveis imediatamente, seja em relatórios financeiros ou em dados do mercado. E, como o retorno é expresso através de uma percentagem do investimento, sua interpretação é clara e objetiva.

Uma característica atraente dos índices de retorno é que eles podem ser decompostos de modo a revelar a origem de suas mudanças. Por exemplo, um baixo retorno sobre os ativos pode ser atribuído a uma baixa atividade, margens pequenas, ou a ambas. Quando se avaliam desempenhos operacionais passadas, de modo a investigar diferentes aspectos da gestão da empresa, ou prever o desempenho futuro, o conhecimento da origem destes retornos é uma informação valiosa. A análise Du Pont é usada para analisar índices de retorno, subdividindose os índices de retorno por suas atividades e componentes do lucro. Esta técnica permite avaliar a origem das mudanças no retorno ano a ano e avaliar as diferenças entre empresas.

As medidas de retorno sobre investimento não são boas para se medir desempenho, por diversas razões. Primeiro, os índices de retorno sobre investimentos são calculados usando-se dados financeiros no numerador e/ou no denominador. Esta sensibilidade aos métodos 
contábeis, torna difícil a comparação entre índices de retorno entre empresa e também ao longo do tempo, requerendo, desse modo, ajustes nos dados contábeis para utilizar os índices de retorno na mesma base contábil.

Segundo, estes índices usam dados financeiros que são um acúmulo de valores monetários de diferentes períodos.

Terceiro, índices de retorno sobre investimentos são voltados para o passado e não para o futuro. Apesar dos efeitos imediatos dos investimentos correntes influenciarem os índices de retorno, os benefícios futuros esperados pelas decisões do período atual não são geralmente incorporados aos índices de retorno.

Um quarta deficiência dos índices de retorno sobre investimentos é que eles falham na consideração de riscos. Estes índices simplesmente usam dados financeiros históricos, que não refletem a incerteza que a empresa enfrenta.

Finalmente, os índices de retorno sobre investimentos não são ajustados aos fatores controláveis e não controláveis. O ideal seria que o desempenho de uma empresa fosse isolado de fatores que estão fora do controle da administração. Também os índices de retorno sobre investimentos refletem somente o lucro líquido e não consideram nenhum outro fator.

O q de Tobin é normalmente usado como uma medida do valor rela criado pela administração de uma empresa. Quanto maior for o q, maior o valor adicionado. O grande atrativo do índice q é que ele fornece uma estimativa dos ativos intangíveis da empresa, os quais incluem a força do mercado, o fundo de comércio, a qualidade da administração e as oportunidades futuras de investimento; quanto maior for o valor destes intangíveis, maior será o valor do q. Por conseguinte, o ranking das empresa, baseadas em seus montantes de valores $q$, serve para 
classificar empresas com base em geração de fluxo de caixa antecipado. Além disso, observando as mudanças nos valores de q de ano a no, fornece ao analista uma idéia de como as oportunidades da empresa mudaram.

O valor do q é o quociente entre o valor de mercado dos ativos de uma empresa e o valor do custo de reposição destes ativos:

$$
q=\frac{\text { Valor de mercado de ativos }}{\text { Custo de reposição dos ativos }}
$$

As medidas tradicionais de desempenho são baseado largamente em dados contábeis; portanto, em qualquer uso que se faça destes instrumentos, deve-se considerar as distorções potenciais que podem surgir na escolha de métodos contábeis. Além disso, estas medidas tradicionais usam, na maior parte das vezes, dados históricos para medir desempenho atuais. $O$ ideal seria medir como as decisões tomadas hoje irão afetar o desempenho futuro da empresa.

\section{II.12. ANÁLISE DE VALOR E ENGENHARIA DE VALOR}

As técnicas de Análise de Valor e de Engenharia de Valor tiveram início durante a última guerra mundial e foram consolidadas efetivamente nos Estados Unidos entre 1947 e 1952.

A ação dessas técnicas voltava-se sobretudo à pesquisa de novos materiais de custo mais baixo de grande disponibilidade, que pudessem substituir outros mais raros e de custo mais elevado, durante os anos de conflito. Terminada a guerra, os citados materiais voltaram a ser acessíveis e os projeto implementados anteriormente foram reexaminados com vistas na reversão às especificações originais. Percebeu-se que as alterações produziram economia sem prejudicar o nível de satisfação do consumidor, tendo-o, em alguns casos, até 
melhorado. A procura criativa de soluções para certo problema possibilita a abertura de novas abordagens e traz também soluções para outros problemas. Nesse caso, a principal finalidade das alterações era a de contornar o problema da escassez durante a guerra e, no entanto, encontraram um potente instrumento de redução de custos. Alguns executivos da General Electric Company, analisando os resultados inesperados, porém bem-vindos, propuseram em 1947 a Lawrence D. Miles sistematizar essas técnicas e desenvolver uma metodologia.

Os estudos de Miles levaram à formulação de uma série de técnicas de análise em torno da idéia de focalizar estudos de produtos em termos de funções em lugar de peças ou componentes. Essa abordagem traria resultados muito promissores, como já se percebia nessa época inicial. Um série de técnicas foi desenvolvida em torno dessa idéia, que, no conjunto, foi chamada de Análise de Valor.

Segundo CSILLAG (1995), a variedade dos assuntos abordados por essa metodologia é enorme podendo ser citados: na indústria química, na igreja, na Transworld Airlines, que iniciou em 1968 um estudo amplo em escala mundial com resultados surpreendentes, na área de hipotecas, na área de manutenção, em ecologia (com vista a preservar cardumes de salmão e de trutas nos rios) e também no mercado de capitais.

De acordo com PARK (1998), custo é um fato; é medido através da quantidade de dinheiro, tempo, trabalho ou outros gastos quaisquer para obter algo desejado. Porém, valor é uma questão de opinião do comprador referente ao que o produto efetivamente vale, baseado no que este objeto significa para ele. Além disto, a medida de valor muda constantemente para se adequar a situações específicas. 
A discussão de valor é como abrir a Caixa de Pandora. Uma vez aberta a caixa, há muitas maneiras de abordar a discussão e, portanto, deve-se definir muito bem o escopo da discussão.

A discussão sobre valor se faz necessário pois o mesmo permite determinar se se gasta os recursos financeiros de forma prudente ou se não se está obtendo um bom valor. A medida de valor fornece uma medida de comparação. Muito embora pode-se não entender a base específica do valor, constantemente se realiza julgamento de valor.

A história do valor retoma aos gregos, onde há referência de Aristóteles identificando sete tipos de valores enquanto que há referências datada de 27 AD indicando seis tipos de valor creditados a Vitrovius. Estes seis tipos são: moral, estético, legal, sentimental, uso e mercado, sendo que os dois últimos se referem ao valor econômico.

Valor, conforme o dicionário de Auréio Buarque de Holanda Ferreira, é o "equivalente justo em dinheiro, mercadoria, etc., especialmente de coisa que pode ser comprada ou vendida".

O valor real de um produto, processo ou sistema é o grau de aceitabilidade de um produto pelo cliente e, portanto, é o índice final do valor econômico. Quanto maior for o valor relacionado de um item sobre outro que sirva para a mesma finalidade, maior será a probabilidade de vencer a concorrência.

O valor real de um produto, serviço ou processo é sempre uma entidade relativa e corresponde à combinação de tipos específicos de valores. Em geral, aumenta com maiores valores de uso e de estima e diminui com o crescimento do valor de custo.

Desde que o objetivo básico seja desempenhar certa função essencial ao mínimo custo ou sacrifício, pode ser concluído que é nessas condições que existirá o valor máximo, ou “valor”. Em outras palavras, o "valor" corresponde ao menor sacrifício ou dispêndio de recursos para 
desempenhar certa função, tanto para o fabricante quanto para o usuário.

\section{II.13. TAXA DE DESCONTO E CUSTO DE CAPITAL}

Segundo DAMODARAN (1997), a taxa de desconto é a taxa a qual o valor presente e o valor futuro são equivalentes. Esta taxa incorpora: (1) a preferência pelo consumo presente; (2) inflação esperada; e (3) a incerteza dos fluxos de caixa futuros.

Porém, este conceito de taxa de desconto é muito amplo, aplicável para calcular valor presente e valor futuro em matemática financeira. Quando se trata de taxa de desconto a ser utilizada para tomada de decisão de investimento, o próprio DAMODARAN (1994) destaca que este item é um ingrediente crítico na precificação através do fluxo de caixa descontado.

Ele apresenta o modelo CAPM (Capital Asset Pricing Model), que indica o custo de capital próprio, como a medida de risco em termos de variância não-diversificável e relaciona o retorno esperado a sua medida de risco. Para tanto, indica que há algumas premissas a serem aceitas: (1) muitos pequenos investidores; (2) mesma informação entre todos; (3) mesma expectativa com relação aos títulos; (4) não restrição a investimentos e nem impostos; (5) não há custos de transação; (6) investidores são racionais e avessos ao risco.

A fim de avaliar o risco não diversificável de uma ativo, deve ser determinado o seu coeficiente $\beta$. Para GITMAN (1997), o coeficiente $\beta$ pode ser visto como um índice do grau de conformidade ou comovimento de retorno do ativo com o retorno do mercado. Os retornos do mercado deveriam ser baseados num amplo índice de todos os ativos com risco, como tal índice não é disponível convenientemente, ele é medido tipicamente através do retorno médio de todos (ou uma grande 
amostra de) ativos. Os índices de ações são geralmente utilizados para medir o mercado. Os betas dos ativos podem assumir valores que sejam positivos ou negativos.

Utilizando o $\beta$ como índice de risco não-diversificável, o modelo de precificação de ativos financeiros é dado por:

$$
R_{e}=R_{f}-\beta\left(R_{m}-R_{f}\right)
$$

Onde:

$R_{e}=$ retorno esperado do ativo

$\mathrm{R}_{\mathrm{f}}=$ retorno exigido do ativo livre de risco

$\beta=$ coeficiente $\beta$

$\mathrm{R}_{\mathrm{m}}=$ retorno exigido da carteira de mercado de ativos

O retorno exigido do ativo é uma função crescente do $\beta$, o qual reflete o risco relevante. Em outras palavras, quanto maior o risco, maior a taxa exigida e vice-versa. $O$ modelo pode ser separado em duas partes: (1) taxa livre de risco, $R_{f}$ e (2) prêmio pelo risco de mercado $\left(R_{m}-R_{f}\right)$, representando o prêmio que o investidor deve receber por tomar o montante médio de risco em relação à conservação da carteira do mercado de ativos.

É possível também se considerar mais de um fator de risco nãodiversificável utilizando-se o modelo APM (Arbitrage Pricing Model). Ou seja, o CAPM é um modelo contido no modelo APM.

O custo de capital é a taxa de retorno que uma empresa precisa obter sobre seus investimentos, de forma a manter inalterado o valor de mercado da empresa. Ela pode ser imaginada como a taxa de retorno exigida pelos investidores de mercado para atrair o financiamento necessário a preço razoável. Mantido constante o risco, projetos com taxa de retorno abaixo do custo de capital diminuirão o valor da 
empresa; projetos com taxa de retorno acima do custo de capital aumentarão seu valor.

Embora o custo de capital seja determinado num dado momento, este deve refletir o custo de fundos por longo prazo, com base nas melhores informações disponíveis. A importância disso deveria ficar especialmente clara já que o custo de capital é usado em investimentos de capital para justificar dispêndios que geram benefícios a longo prazo. Do mesmo modo que a empresa estima cuidadosamente o investimento inicial e as entradas de caixa associadas a um dispêndio de capital, ela deve também estimar com cuidado seu custo de capital. Erros em qualquer dessas atividades poderiam resultar em uma seleção de projetos não-aceitáveis ou na rejeição de projetos aceitáveis.

O cálculo do custo total de capital para uso na avaliação dos investimentos em perspectiva é feito após a determinação dos cálculos de fontes específicas de capital (exigível a longo prazo, ações ordinárias e preferenciais). O Custo Médio Ponderado de Capital (CMePC) é encontrado ponderando-se o custo de cada tipo específico de capital por sua proporção na estrutura de capital da empresa.

Este cálculo é feito multiplicando-se o custo específico de cada fonte de financiamento por sua proporção na estrutura de capital da empresa e somando-se os valores ponderados. O CMePC pode ser especificado numa equação, como se segue:

Onde:

$$
\mathrm{CMePC}=\mathrm{ka}=\left(\mathrm{w}_{\mathrm{i}} \times \mathrm{k}_{\mathrm{i}}\right)+\left(\mathrm{w}_{\mathrm{p}} \times \mathrm{k}_{\mathrm{p}}\right)+\left(\mathrm{w}_{\mathrm{s}} \times \mathrm{k}_{\mathrm{r} \text { ou } n}\right)
$$

$\mathrm{W}_{\mathrm{i}}=$ proporção de empréstimo a longo prazo

$\mathrm{w}_{\mathrm{p}}=$ proporção de ações preferenciais

$\mathrm{w}_{\mathrm{s}}=$ proporção de ações ordinárias

$\mathrm{w}_{\mathrm{i}}+\mathrm{w}_{\mathrm{p}}+\mathrm{w}_{\mathrm{s}}=1$

$\mathrm{k}_{\mathrm{i}}=$ custo do empréstimo a longo prazo

$\mathrm{k}_{\mathrm{p}}=$ custo da ação preferencial

$\mathrm{k}_{\mathrm{r} \text { oun }}=$ custo dos lucros retidos ou da emissão de novas ações ordinárias 
Capítulo III:

METODOLOGIA DA PESQUISA 


\section{METODOLOGIA DE PESQUISA}

As ciências sociais constituem áreas do conhecimento que estudam e procuram descrever os fenômenos sociais, econômicos, políticos, psicológicos, culturais e educacionais, entre outros, que englobam relações de caráter humano e social (GODOY, 1995)

Intuitivamente é perceptível que o conhecimento neste campo é inexaurível e incompleto: inexaurível por sofrer influência de fatores variáveis ao longo do tempo e que, portanto, necessitam de constante verificação sobre a atual prática; incompleto porque nem sempre as obras referentes explicam como foram fixados os preços das negociações, havendo nelas, portanto, várias "lacunas".

Como conseqüência dessas duas características básicas, surgiram diversos métodos de trabalho, estilos de análise e de apresentação de resultados, os quais constituem alternativa de metodologia de trabalhos científicos e, em última instância, definem a metodologia de pesquisa que os haverá de sustentar.

\section{III.1. METODOLOGIAS EXISTENTES}

As pesquisas podem essencialmente ser classificadas quanto à natureza da variável pesquisada, ao objetivo que pretende atingir e ao grau em que o problema de pesquisa está cristalizado.

\section{III.1.1. COM RELAÇÃO À NATUREZA DA VARIÁVEL PESQUISADA}

A pesquisa qualitativa busca inferir uma possível explicação (teoria) a partir do mundo real, ao passo que a quantitativa baseia-se, a priori, no pressuposto de que a teoria pode, ou não, ser verificada. 
A pesquisa qualitativa é mais completa, ela atua mediante um embasamento teórico e, dessa forma, possibilita sensibilidade para outras experiências realizadas acerca de temas relacionados.

\begin{tabular}{|c|c|c|}
\hline Característica & Pesquisa Qualitativa & $\begin{array}{l}\text { Pesquisa } \\
\text { Quantitativa }\end{array}$ \\
\hline $\begin{array}{l}\text { Objeto } \\
\text { Pesquisa }\end{array}$ & $\begin{array}{l}\text { A realidade subjetiva, a } \\
\text { qual pode ser dividida ou } \\
\text { entendida }\end{array}$ & $\begin{array}{l}\text { A realidade objetiva, a } \\
\text { qual pode ser } \\
\text { identificada e medida }\end{array}$ \\
\hline $\begin{array}{l}\text { Modo de } \\
\text { trabalhar com a } \\
\text { teoria }\end{array}$ & Descobre a Teoria & $\begin{array}{l}\text { Testa relações } \\
\text { baseadas na teoria }\end{array}$ \\
\hline $\begin{array}{l}\text { Revisão } \\
\text { Literatura }\end{array}$ & $\begin{array}{l}\text { Limitada nos estágios } \\
\text { iniciais e intensiva nos } \\
\text { estágios posteriores }\end{array}$ & $\begin{array}{l}\text { Extensiva a fim de } \\
\text { justificar questões } \\
\text { sobre os estudos e } \\
\text { teorias }\end{array}$ \\
\hline $\begin{array}{l}\text { Instrumento } \\
\text { utilizado e seus } \\
\text { efeitos }\end{array}$ & $\begin{array}{l}\text { O pesquisador é } 0 \\
\text { instrumento e pode } \\
\text { influenciar os dados }\end{array}$ & $\begin{array}{l}\text { Utiliza instrumentos } \\
\text { que aumentam a } \\
\text { objetividade }\end{array}$ \\
\hline $\begin{array}{l}\text { Processo de } \\
\text { Pesquisa }\end{array}$ & $\begin{array}{ll}\text { Circular } & \text { (comparações } \\
\text { constantes) } & \end{array}$ & Seqüencial \\
\hline
\end{tabular}

Fonte: Rempushesk, 1997

\section{TABELA 6 - CARACTERÍSTICAS DA PESQUISA QUALITATIVA E QUANTITATIVA}

Segundo Kirk e Miller (MATTAR, 1994: 81), a característica diferenciadora entre esses dois tipos de pesquisa é que a qualitativa "identifica a presença ou ausência de algo", enquanto que a quantitativa "procura medir o grau em que algo está presente".

Apesar de as orientações filosóficas serem diferenciadas, é admitido o desenvolvimento de uma pesquisa que contemple ambas as 
metodologias, ou seja, uma pesquisa que, além de indicar o modo pelo qual as pessoas pensam sobre as naturezas do mundo, explicite o grau de importância de uma variável independente com relação a outra, dependente. Tal possibilidade foi admitida por REMPUSHESK (1997), pelo método denominado triangulação, que seria justificada nos casos em que a mensuração objetiva (quantitativa) alterasse a pesquisa suficientemente para justificar o questionamento dos significados subjetivos.

\section{III.1.2. COM RELAÇÃO AO OBJETIVO E AO GRAU EM QUE O PROBLEMA DE PESQUISA ESTÁ CRISTALIZADO}

SELLTIZ e outros (1975: 5) afirmaram que o objetivo ao realizar-se uma pesquisa é "descobrir respostas para perguntas através do emprego de processos científicos" e alertaram que não existe garantia de que qualquer pesquisa apresente informação significativa, precisa e não viesada.

Dessa forma, o tipo de pesquisa a ser implementada seria direcionada pelo conhecimento do pesquisador sobre o tema a ser pesquisado e pelo conseqüente grau de definição do tema com relação:

$\checkmark$ ao conhecimento do pesquisador sobre o que se pretende com a pesquisa;

$\checkmark$ ao conhecimento do pesquisador sobre o que se deseja medir;

$\checkmark$ a quando, onde, como e por que deverá fazer a pesquisa (Mattar, 1994: 90)

\section{III.1.3. PESQUISA EXPLORATÓRIA}

$\mathrm{Na}$ concepção de SELLTIZ e outros (1959), é o tipo de pesquisa utilizado quando os pesquisadores buscam familiarizar-se com um fenômeno ou conseguir a sua compreensão, visando a melhor definição 
do problema ou a criação de novas hipóteses. Tal tipo de pesquisa geralmente é utilizada:

$\checkmark$ nos primeiros estágios da investigação científica;

$\checkmark$ para ajudar a estabelecer as prioridades a serem pesquisadas;

$\checkmark$ para classificar conceitos (Mattar, 1994).

Os estudos exploratórios não verificam nem formulam hipóteses, restringem-se a conduzir a possíveis explicações do fenômeno observado, sendo, dessa forma, um primeiro passo para a elaboração de estudos nos quais sejam exercidos maiores controles, para verificar se as hipóteses que surgem têm a aplicabilidade geral.

Entre os principais métodos existentes para a realização de estudos exploratórios estão levantamentos bibliográficos, levantamentos documentais, estudos de caso e observação informal.

O levantamento bibliográfico é indicado para o pesquisador "amadurecer" ou aprofundar problema de pesquisa e pode ser realizado por meio de consultas em livros, trabalhos acadêmicos, artigos na imprensa, associações ligadas ao tema de pesquisa, entre outros.

A pesquisa documental implica a utilização de documentos públicos ou de outros cujo acesso é restrito, para levantar fatos ou hipóteses a respeito do fenômeno a ser estudado.

O estudo de casos é um método que envolve, entre outras possibilidades, o exame de registros existentes, a observação da ocorrência do fato e a utilização de entrevistas. Tal método tem por objetivo gerar hipóteses e estimular a compreensão para a pesquisa.

MATTAR (1994) teceu considerações sobre estudos de caso, quanto a:

$\checkmark$ profundidade da análise, permite 0 detalhamento dos casos em estudo e a comparação com outros casos estudados;

$\checkmark$ receptividade do pesquisador, sua atitude deve ser de buscar informações e gerar hipóteses; multiplicidade de aspectos do estudo, 
o pesquisador deve ser capaz de integrar e reunir inúmeros aspectos do objeto pesquisado.

Os estudos de caso geralmente ocorrem em situações extremadas, nas quais o pesquisador sabe, de antemão, que encontrará as características que procura em alto grau.

O último método, a observação informal, é a análise contínua de objetos, comportamentos e fatos ao redor do pesquisador, permitindoIhe utilizar sua capacidade de percepção sobre objetos, comportamentos e fatos de interesse para o problema em estudo.

\section{III.1.4. PESQUISA CONCLUSIVA DESCRITIVA}

"As questões de estudo descritivos pressupõem muitos conhecimentos anteriores do problema a ser pesquisado, ao contrário do que ocorre com as questões que constituem o fundamento para os estudos exploratórios" (Selltiz e outros, 1959: 77).

As pesquisas conclusivas são bem-estruturadas e propõem objetivos bem-definidos. Geralmente tratam da descrição das características das comunidades e dos seus padrões de comportamento, requerendo, na sua condução, maior preocupação com o viés do que nas pesquisas exploratórias - requer informações exatas e completas.

Os principais métodos utilizados para realização de estudos descritivos são:

$\checkmark$ levantamento de campo, que pressupõe um grande conhecimento técnico do pesquisador e trabalha com uma população representativa (gerada a partir de métodos probabilísticos);

$\checkmark$ estudo de campo, que trabalha com uma amostra dos elementos da população de interesse e atende a um objetivo específico. 


\section{III.1.5. PESQUISA CASUAL}

É realizado quando o pesquisador tem como objetivo determinar as causas das ocorrências. O método mais utilizado é a experimentação, no qual uma ou mais variáveis independentes são controladas ou manipuladas pelo pesquisador, que procede à medição do efeito destas sobre a variável dependente.

'As pesquisas causais são conduzidas para verificar hipóteses formuladas sobre condições contribuintes para o efeito em estudo. Tais pesquisas nunca esgotam a determinação de variáveis causadoras de um efeito - o que é sempre questionável por meio de estudos exploratórios.

Algumas precauções metodológicas devem ser tomadas para extrair inferências a respeito das causas contributivas para a ocorrência de um determinado efeito:

$\checkmark$ a consideração da sincronia temporal das variáveis em contribuir para a ocorrência do efeito;

$\checkmark$ a verificação da adequabilidade da escolha do grupo experimental para a pesquisa (Selltiz e outros, 1959)

\section{III.2. METODOLOGIA DE PESQUISA ADOTADA}

A metodologia de pesquisa adotada para o desenvolvido deste trabalho baseou-se no modelo desenvolvido por BERGER e OFEK (1995).

Para verificar se a diversificação aumenta ou diminui o valor da empresa, mediu-se a diferença percentual entre o valor total da empresa e o seu valor atribuído que é a soma das UEN como se fossem entidades autônomas. Esta soma é calculada através da multiplicação da razão das medianas entre capital total e um dos três itens contábeis (ativos, vendas e LAJIR) de empresas com uma UEN pelo mesmo item contábil da empresa com vários UEN. 
As razões das medianas da indústria são baseadas em grupos mais próximos possíveis do SIC (Standard Industrial Classification) que inclui ao menos cinco negócios com uma linha com ao menos US\$20 milhões de vendas por ano e dados suficientes para computar as razões. As equações 1 e 2 ilustram o modelo proposto:

$$
\begin{aligned}
& \left.\mathrm{I}(\mathrm{V})=\sum \mathrm{I}_{\mathrm{i}}^{*} \operatorname{lnd}_{\mathrm{i}}(\mathrm{V} / \mathrm{AI})_{\mathrm{mf}}\right) \\
& \mathrm{EXVAL}=\ln (\mathrm{V} / \mathrm{I}(\mathrm{V})),
\end{aligned}
$$

onde

Equação 1 - I(V) = valor atribuído pela soma das UEN da empresa como se fossem empresas independentes,

$A l_{i}=$ valor do item contábil (vendas, ativos ou LAJIR) para a UEN $i$

$\mathrm{Ind}_{\mathrm{i}}(\mathrm{V} / \mathrm{Al})_{\mathrm{mf}}=$ múltiplo da razão entre as medianas do capital total e do item contábil (vendas, ativos ou LAJIR) da empresa com uma única UEN para o segmento $i$ da indústria

Equação 2 - EXVAL = variação do valor da empresa

$\mathrm{V}$ = capital total da empresa (valor de mercado das ações mais o valor contábil do passivo)

$\mathrm{n}=$ número total de UEN da empresa.

A Equação 1 mostra que o valor atribuído da empresa é a somatória do produto entre determinado item contábil da UEN e a razão da mediana do capital total da empresa pelo valor do item contábil desta empresa com uma UEN. A Equação 2 mostra que a medida da variação de valor da empresa é o logaritmo natural da razão entre o valor real da empresa e seu valor atribuído. 
A soma dos valores atribuídos de UEN da companhia estimará o valor da empresa como se todos suas UEN fossem operadas como negócios autônomos. O logaritmo natural da razão entre valor real de uma empresa e seu valor atribuído será a medida de variação do valor, ou o ganho ou a perda no valor da diversificação. A variação de valor positivo indica que a diversificação aumenta o valor das UEN além daquele de suas contrapartes autônomas. A variação de valor negativo indica que a diversificação reduz o valor.

A validade da aproximação do multiplicador (vendas, ativos e LAJIR) depende das políticas da divulgação dos dados da empresa. Os modelos teóricos de decisões gerenciais sobre divulgação de resultados sugerem que os executivos podem ter incentivos para não apresentarem os dados corretamente tanto para os fornecedores de concorrentes do mercado de capital como de produto. A alteração dos demonstrativos depende da possibilidade dos gerentes em alocar investimentos entre UEN. Dado que os ativos das UEN devem ser especificamente identificáveis com o unidade para que são relatados, há pouca possibilidade em alterá-los. Os executivos têm alguma possibilidade de alocar vendas e uma possibilidade maior para alocar despesas, tendo assim as vendas da UEN e o lucro (vendas menos despesas) mais vulneráveis à manipulação. GIVOLY, HAYNN e D'SOUZA (1993) definem a qualidade da UEN reportado como sendo a diferença entre a correlação das medidas contábeis das unidades com aquelas das suas indústrias e a correlação das medidas das empresas com uma linha nas mesmas indústrias com as medidas agregadas da indústria. Eles encontram uma diferença marginal significativa em um coeficiente de correlação de 0,061 para vendas e uma diferença significativa de 0,146 para o lucro. Assim, há alguma evidência que os números do lucro da UEN não podem ser tão confiáveis quanto as vendas e os valores dos 
ativos. Entretanto, o multiplicador do lucro tem a vantagem de atribuir o valor diretamente da rentabilidade atual, que pode estar mais diretamente ligada ao valor da empresa que vendas ou ativos.

Estudar a diversificação através do método proposto tem diversas vantagens sobre outros métodos. Por exemplo, um estudo do evento requer uma data claramente definida do mesmo. É difícil de se identificar a data precisa de um evento que faça saber sem ambigüidade o efeito da informação sobre a diversificação. A resposta do preço da ação aos anúncios do takeover pode refletir os termos da oferta, da probabilidade do sucesso ou da informação sinalizada sobre oportunidades na linha do negócio da empresa adquirente. Assim, é difícil identificar claramente as atitudes do investidor sobre a diversificação através do exame da resposta do preço da ação na data do anúncio.

O índice $q$ de Tobin é usado também extensamente nos estudos que examinam como o nível do valor da empresa varia em função da variação da sua estrutura. O cálculo do q de Tobin requer suposições sobre taxas da depreciação e da inflação para estimar o valor de reposição da empresa. Além disto, os estudos de precificação não ajustam o índice para a indústria apesar de haver grande variação entre elas. Utilizar o índice ajustado é, entretanto, problemático no estudo da diversificação, porque nem os valores de mercado da UEN nem os valores de reposição da mesma podem ser computados diretamente dos dados disponíveis. Adicionalmente, o estudo de eventos e os estudos que avaliam efeitos do valor usando o q de Tobin fornecem somente oportunidades limitadas de examinar as fontes potenciais dos ganhos ou das perdas da diversificação. O método proposto fornece não somente uma estimativa direta da variação de valor associado com a diversificação, mas permite também uma investigação adicional no nível da UEN das fontes de variação do valor. 


\section{III.2.1. USO DOS MÚLTIPLOS PARA VERIFICAR A VARIAÇÃO DE VALOR}

\section{III.2.1.1. VENDAS}

Para calcular a variação de valor utilizando-se do multiplicador de vendas, multiplica-se a razão das medianas entre capital total e vendas das empresas com uma UEN pelas vendas da mesma unidade da empresa com várias UEN. Repetir-se-á este processo para cada uma das UEN que então serão somados para se obter o valor atribuído da empresa. Finalmente, encontrar-se-á a variação de valor da empresa através do logaritmo natural da razão entre o valor real da empresa e seu valor atribuído. Os valores adicionais extremos serão excluídos da análise. O extremo é definido para todos os três multiplicadores como sendo o logaritmo natural da razão entre o valor real e o valor atribuído acima de $+1,386$ ou abaixo de $-1,386$ (isto é, valores reais mais que quatro vezes do valor atribuído, ou menores que um quarto).

\section{III.2.1.2. ATIVOS}

Os valores atribuídos do multiplicador do ativo são encontrados de maneira análoga. Outra preocupação que se levanta é que é mais comum os valores dos ativos das UEN apresentadas na base de dados da CIS serem diferentes da base de dados do Compustat do que com as vendas. A soma das UEN é geralmente menor do que o total da empresa, indicando que o problema surge com os ativos não-alocados. Tratar-se-á deste problema através de dois meios alternativos: se a soma dos ativos das UEN para uma empresa desviar mais do que $25 \%$ dos ativos das empresas, excluir-se-á a observação de todas as análises usando os múltiplos de ativos. Se o desvio estiver dentro de $25 \%$, ajustar-se-á o valor atribuído da empresa para refletir o fato que os múltiplos estão multiplicados pelos números dos ativos da UEN e que são demasiado pequenas ou demasiado grandes. Especificamente, o 
valor atribuído da empresa é ajustado para acima ou para baixo pelo desvio da porcentagem entre a soma dos ativos da UEN e de ativos totais das empresas. A medida da variação de valor baseada em múltiplos do ativo é encontrada então na mesma maneira que a medida usando múltiplos das vendas, com a exclusão dos valores extremos.

\section{III.2.1.3. LAJIR - LUCRO ANTES DOS JUROS E IMPOSTO DE RENDA}

Os valores atribuídos do múltiplo do LAJIR (Lucro Antes dos Juros e Imposto de Renda ou Lucro Operacional) usam os mesmos procedimentos de ajuste que os valores atribuídos aos múltiplos do ativo. Uma preocupação adicional que se levanta com a medida do LAJIR é como tratar UEN com o LAJIR negativo, dado que o modelo do multiplicador não atribui tipicamente valor negativo às empresas com lucro negativo. Procurar-se-á solucionar este problema substituindo o valor atribuído do multiplicador de LAJIR pelo multiplicador de valor atribuído LAJIR+D (que inclui a depreciação), se positivo, ou com o valor atribuído do múltiplo das vendas da UEN.

\section{III.3. TAMANHO DA AMOSTRA}

O detalhamento da amostra está descrito no próximo capítulo. Em suma, foram analisadas as empresas norte-americanas do setor de telecomunicações que se encaixam na classificação como vendors entre o período de 1990 e 1999 e que tenham apresentado faturamento líquido anual maior ou igual a US\$20 milhões e não apresentem UEN na indústria de serviços financeiros. Para evitar distorções nas valorizações das empresas com vendas e ativos próximos de zero, exige-se o faturamento líquido mínimo acima. A restrição às empresas com UEN na indústria de serviços financeiros deve-se a problemática de se aplicar os métodos de valorização de empresas neste setor. Além 
disto, muitas empresas deste segmento não apresentam lucro líquido após o imposto de renda por falta de sentido.

\section{III.4. ESTRATÉGIA DE COLETA DOS DADOS}

A coleta de dados ocorreu através da consulta dos bancos de dados da CIS, Securities Data Company, Bloomberg pelo próprio autor do trabalho entre os meses de maio e julho de 2001.

O banco de dados da CIS foi utilizado como base assim como no trabalho original de BERGER e OFEK (1995). Os outros dois bancos foram utilizados como suporte para complementação dos dados inexistentes no banco da CIS ou validação de dados divergentes, especialmente com relação à quantidade de UEN por empresa. No caso em que a validação não foi possível, optou-se pela eliminação do mesmo da amostra.

A estrutura do banco de dados da CIS é dividido em 10 categorias:

\begin{tabular}{|c|c|c|}
\hline CATEGORIA & DESCRIÇÃO & Classificação \\
\hline A. & Agriculture & SIC $0111-0971$ \\
\hline B. & Mining & SIC $1011-1499$ \\
\hline C. & Construction & SIC $1521-1799$ \\
\hline D. & Manufacturing & SIC $2011-3999$ \\
\hline E. & $\begin{array}{l}\text { Transportation, Communications, } \\
\text { Electric, Gas, and Sanitary Services }\end{array}$ & SIC $4011-4971$ \\
\hline F. & Wholesale Trade & SIC $5012-5199$ \\
\hline G. & Retail Trade & SIC $5211-5999$ \\
\hline $\mathrm{H}$. & Finance, Insurance, Real Estate & SIC $6021-6799$ \\
\hline I. & Services & SIC $7011-8999$ \\
\hline $\mathrm{K}$. & Nonclassifiable Establishments & SIC 9999 \\
\hline
\end{tabular}


Para o trabalho em questão, a categoria de interesse era a D:Manufacturing. Esta categoria se subdivide em grupos que são apresentados a seguir:

\begin{tabular}{|c|c|}
\hline Grupo & Descrição \\
\hline 20 & Food And Kindred Products \\
\hline 21 & Tobacco Products \\
\hline 22 & Textile Mill Products \\
\hline 23 & Apparel And Other Finished Products Made From Fabrics \\
\hline 24 & Lumber And Wood Products, Except Furniture \\
\hline 25 & Furniture And Fixtures \\
\hline 26 & Paper And Allied Products \\
\hline 27 & Printing, Publishing, And Allied Industries \\
\hline 28 & Chemicals And Allied Products \\
\hline 29 & Petroleum Refining And Related Industries \\
\hline 30 & Rubber And Miscellaneous Plastics Products \\
\hline 31 & Leather And Leather Products \\
\hline 32 & Stone, Clay, Glass, And Concrete Products \\
\hline 33 & Primary Metal Industries \\
\hline 34 & Fabricated Metal Products, Except Transportation Equipment \\
\hline 35 & Industrial And Commercial Machinery And Computer Equipment \\
\hline 36 & $\begin{array}{l}\text { Electronic And Other Electrical Equipment And Components, } \\
\text { Except Computer Equipment }\end{array}$ \\
\hline 37 & Transportation Equipment \\
\hline 38 & $\begin{array}{l}\text { Measuring, Analyzing, And Controlling Instruments; Photographic, } \\
\text { Medical, And Optical Goods; Watches And Clocks }\end{array}$ \\
\hline 39 & Miscellaneous Manufacturing Industries \\
\hline
\end{tabular}


Das categorias existentes, a que continha o setor a ser estudado era a categoria 36. Esta categoria é composta da seguinte forma:

\begin{tabular}{|l|l|}
\hline Grupo & Descrição \\
\hline 3612 & Power, Distribution, and Specialty Transformers \\
\hline 3613 & Switchgear and Switchboard Apparatus \\
\hline 3621 & Motors and Generators \\
\hline 3624 & Carbon and Graphite Products \\
\hline 3625 & Relays and Industrial Controls \\
\hline 3629 & Electrical Industrial Apparatus, N.E.C. \\
\hline 3631 & Household Cooking Equipment \\
\hline 3633 & Household Refrigerators and Home and Farm Freezers \\
\hline 3634 & Electric Housewares and Fans \\
\hline 3635 & Household Vacuum Cleaners \\
\hline 3639 & Household Appliances, N.E.C. \\
\hline 3641 & Electric Lamp Bulbs and Tubes \\
\hline 3643 & Current-Carrying Wiring Devices \\
\hline 3644 & Noncurrent-Carrying Wiring Devices \\
\hline 3645 & Residential Electric Lighting Fixtures \\
\hline 3646 & Commercial, Industrial, and Institutional Electric Lighting Fixtures \\
\hline 3647 & Vehicular Lighting Equipment \\
\hline 3648 & Lighting Equipment, N.E.C. \\
\hline 3651 & Household Audio and Video Equipment \\
\hline 3652 & Phonograph Records and Prerecorded Audio Tapes and Disks \\
\hline 3661 & Telephone and Telegraph Apparatus \\
\hline 3663 & $\begin{array}{l}\text { Radio and Television Broadcasting and Communications } \\
\text { Equipment }\end{array}$ \\
\hline 3669 & Communications Equipment, N.E.C. \\
\hline
\end{tabular}




\begin{tabular}{|l|l|}
\hline Grupo & Descrição (continuação 1) \\
\hline 3671 & Electron Tubes \\
\hline 3672 & Printed Circuit Boards \\
\hline 3674 & Semiconductors and Related Devices \\
\hline 3675 & Electronic Capacitors \\
\hline 3676 & Electronic Resistors \\
\hline 3677 & Electronic Coils, Transformers, and Other Inductors \\
\hline 3678 & Electronic Connectors \\
\hline 3679 & Electronic Components, N.E.C. \\
\hline 3691 & Storage Batteries \\
\hline 3692 & Primary Batteries, Dry and Wet \\
\hline 3694 & Electrical Equipment for Internal Combustion Engines \\
\hline 3695 & Magnetic and Optical Recording Media \\
\hline 3699 & Electrical Machinery, Equipment, and Supplies \\
\hline
\end{tabular}

\section{TABELA 9 - SUBDIVISÃO DA CATEGORIA 36 - ELETRONIC}

Enfim, obteve-se a categoria a 3661 - Telephone and Telegraph Apparatus, que contempla as empresas fornecedoras de equipamentos e serviços das operadoras de telefonia fixa e móvel, objeto deste estudo.

\section{III.5. TRATAMENTO E ANÁLISE DOS DADOS}

A escala das variáveis é nominal e para o estudo em questão, tinha-se o conhecimento dos parâmetros da população. Logo, foram utilizadas técnicas paramétricas. A característica e análise dos dados conduziram para a utilização dos métodos inferenciais.

As variáveis que indicaram se houve ou não aumento na riqueza do acionista são as vendas, ativos e LAJIR, portanto, a análise foi multivariada sem a utilização de amostras já que se pretendia trabalhar 
com toda a população. Como é uma análise multivariada, observou-se a existência de grau de dependência entre as variáveis.

\section{III.6. INSTRUMENTOS DE MEDIDA}

A forma como foi medida a população se deu através de testes de dados secundários conforme descrito no trabalho de BERGER e OFEK (1995).

A discussão do método desenvolvido por ambos encontra-se descrito no item III.2 - Metodologia de Pesquisa Adotada, onde se apresenta as duas equações básicas para verificação do ganho ou perda de valor para o acionista.

\section{III.7. LIMITAÇÕES DO MÉTODO}

A limitação do método que se encontra na consecução do objetivo diz respeito às desconsiderações estratégicas de longo prazo que as empresas possam vir a assumir no processo de fusão e aquisição. Neste estudo, não se considera a possibilidade de os acionistas admitirem uma estratégia que venha a trazer perda de valor nos primeiros anos com o objetivo de obter um ganho compensador no longo prazo. 
Capítulo IV:

A PESQUISA 


\section{A PESQUISA}

\section{IV.1. IDENTIFICAÇÃO DA AMOSTRA}

O objetivo desta pesquisa é a análise do efeito da diversificação nas empresas de telecomunicações (vendors) de acordo com o modelo de BERGER e OFEK. Portanto, a amostra deste estudo baseou-se na classificação das empresas dentro do subgrupo 3661 do SIC.

De acordo com as regras contábeis norte-americanas FASB $n^{0 .} 14 \mathrm{e}$ com as regulamentações Comissão de Valores Mobiliários (Securities Exchange Comission), as empresas são obrigadas a demonstrarem as informações no final do ano fiscal também para as suas UEN. Estas empresas devem apresentar informações auditadas e com notas explicativas por UEN cujas vendas, ativos e resultados excedam $10 \%$ do total consolidado. O banco de dados do Compustat Industry Segment (CIS) apresenta informações para todas as empresas ativas além de suas subsidiárias. Para aproximadamente 6.500 empresas por ano, o arquivo contém informações de cinco variáveis por UEN (vendas líquidas, lucro antes do juros e imposto de renda, depreciação, investimento de capital e ativos) assim como a quantidade de UEN contidos na empresa.

Porém, os dados que interessavam para a realizam deste estudo eram das empresas norte-americanas de telecomunicações, especificamente os fornecedores de infra-estrutura para as operadoras telefônicas conhecidos como vendors.

Na seleção da amostra, utilizou-se o subgrupo 3661 como filtro. Todas as empresas que estavam classificadas dentro deste grupo foram selecionadas juntamente com o campo do banco de dados SIC chamado "parental group". Através deste campo foi possível agrupar 
todas as UEN de acordo com a empresa a que pertencia, ou seja, foi possível identificar as diferentes UEN que faziam parte de um mesmo grupo industrial.

Através da identificação do campo parental group, foi possível selecionar outras UEN que não pertenciam ao subgrupo 3661 do SIC mas que pertencia ao mesmo grupo de UEN dos já selecionados. Este procedimento demonstrou que existe diversificação entre empresas de subgrupos diferentes.

O critério de seleção da amostra levou em consideração a obrigatoriedade de empresas do subgrupo 3661 ser predominante quanto ao volume de vendas, para que fosse incluída na amostra. Entendeu-se que o fato de uma empresa de telecomunicações (subgrupo 3661) pertencer a um grupo de empresas não era suficiente para ser incluída na amostra. Era necessário que fosse a principal UEN em vendas.

Uma vez selecionada a amostra, ela foi agrupada de acordo com o campo parental group. Como o banco de dados SIC fornecia a quantidade de UEN dentro da empresa-mãe, este número foi verificado junto a amostra. Adiante é tratado o critério de exclusão dos dados.

Obteve-se os dados das empresas que constavam neste banco de dados entre os anos de 1990 e 1999 que apresentaram vendas líquidas superiores a US\$20 milhões e que não tiveram UEN nas indústria de serviços financeiros (código SIC entre 6000 e 6999). A fim de evitar distorções na valorização dos múltiplos para empresas com vendas líquidas ou ativos próximos de zero, colocou-se este volume de vendas líquidas como limitador. Empresas com segmentos na indústria de serviços financeiros foram eliminadas das considerações pois os métodos de valorização utilizados neste estudo para estas empresas são problemáticos. Especificamente, muitas empresas da indústria de 
serviços financeiros não possuem informações disponíveis de lucro líquido antes dos juros e imposto de renda dado que estes ganhos não são significativos para estas empresas. Para serem incluídas na amostra final, as corporações diversificadas deveriam ter dados tanto no banco de dados da CIS como no banco de dados da Compustat. Adicionalmente, o capital total (medido pelo valor de mercado do patrimônio líquido no dia 31 de dezembro de cada ano mais o valor contábil dos empréstimos também na mesma data-base) para estas empresas deveria estar disponível. Com exceção de ativos e do lucro, as vendas são usualmente alocadas entre as diferentes UEN demonstrados para empresas diversificadas. Desta forma, exigiu-se que a soma das vendas das UEN fosse em torno de $1 \%$ das vendas totais da empresa.

\section{IV.1.1. PRINCIPAIS UEN}

Da seleção descrita anteriormente, foi gerada uma amostra que foi classificada de acordo com a mesma classificação do subgrupo 3661 . Mesmo que estas empresas não fossem dominantes por qualquer que seja o critério sobre as demais do seu grupo, classificou-se a amostra de acordo com os grupos existentes nesta categoria. Para que este agrupamento existisse foi necessário criar um critério e decidiu-se pelo volume de vendas. Todas as empresas que apresentavam a classificação 3661 foram agrupadas de acordo com o campo segment do banco de dados SIC. Em seguida, verificou-se a participação das UEN classificadas como 3661 dentro de seu próprio grupo de empresas tendo como base o ano de 1999. Aquelas empresas que apresentavam UEN classificadas como 3661 mas que não possuíam o maior valor de vendas dentre as demais unidades da empresa, foram excluídas. 
Desta seleção realizada, separaram-se dois grupos: o primeiro, constava de empresas que reportaram uma única UEN durante todo o período do estudo e no segundo grupo, empresas diversificadas que apresentavam durante o mesmo período de estudo várias UEN. Uma nova seleção foi feita nesta seleção inicial. Do segundo grupo, foram excluídas as empresas que não apresentavam as unidades de negócio classificadas como 3661 como principal unidade de negócio. A medida utilizada foi as vendas líquidas. Agindo desta forma, objetivou-se manter no estudo aquelas empresas que poderiam ser caracterizadas como empresas de telecomunicações e que diversificaram em outras UEN.

Adotou-se o ano de 1999 como ano de validação do percentual da UEN pois entendeu-se que as empresas diversificadas que pretendiam atuar neste segmento, direcionaram seus investimentos durante a década de 90 para o mercado de telecomunicações.

Para aquelas empresas que apresentavam mais de uma alternativa de classificação, optou-se por classificar a empresa de acordo com a UEN de maior volume de vendas. Ou seja, para empresas que apresentavam UEN tanto de telefonia fixa como telefonia móvel, classificou-se as empresas deste grupo de acordo com o UEN de maior volume financeiro de vendas.

A partir deste agrupamento, decidiu-se montar seis grupos de UEN: 


\begin{tabular}{l|r}
\hline UEN & \% VENDAS \\
\hline Telefonia Fixa & 29,4 \\
\hline Telefonia Móvel & 28,2 \\
\hline Infra-estrutura & 11,3 \\
\hline Comunicação de Dados & 11,1 \\
\hline Transmissão & 7,1 \\
\hline Outros & 12,9 \\
\hline
\end{tabular}

TABELA 10 - AGRUPAMENTO POR UEN BASEADO EM VENDAS

As UEN Telefonia Fixa e Telefonia Móvel representam a maioria pelo critério de vendas. Estas empresas são fornecedoras de equipamentos e serviços para as operadoras de telefonia fixa e móvel, respectivamente. As empresas pertencentes a este grupo fornecem equipamentos tais como centrais de comutação e controle e estações rádio base.

A UEN Infra-estrutura é representado por empresas que fornecem os equipamentos para que as centrais de comutação e controle assim como as estações rádio base funcionem. Neste grupo inclui-se as torres de transmissão, obra civil, equipamentos de alimentação de energia e ar-condicionado e containers.

Já a UEN Comunicação de Dados é o segmento mais recente dentre os apresentados pois refere-se a transmissão de informação via microondas, fibras ópticas e fios metálicos. A comunicação de dados embora já existente, tomou impulso com a expansão da Internet pois são justamente as empresas deste grupo que fornecem os equipamentos necessários ao tráfego da informação. As empresas deste segmentos fornecem equipamentos tais como roteadores $\mathrm{e}$ equipamentos de comutação por pacotes. 
A UEN Transmissão compreende as empresas que produzem equipamentos tais como rádios de microondas, antenas, satélites e demais equipamentos responsáveis pelo meio de envio e recebimento de informações quer seja por meio de comutação por circuitos quer seja por meio de comutação de pacotes. Muito embora estas empresas sejam dependentes de outros segmentos, principalmente de telefonia, elas também realizam negócios independentes. Estas empresas são fornecedoras de soluções que requerem expansão da capacidade de transmissão, onde não exige o crescimento dos equipamentos de telefonia ou mesmo de infra-estrutura.

A última UEN apresentado refere-se a vários pequenos segmentos que atuam na periferia destes principais tais como fornecedores de circuitos impressos, fios e cabos, entre outros.

Portanto, assumiu-se que os grupos criados representam o principal segmento da empresa pelo critério volume de vendas anuais.

\section{IV.1.2. EXCLUSÃO DOS DADOS}

A partir desta seleção, compôs-se o banco de dados inicial a ser utilizado no estudo que foi chamado de amostra preliminar. Porém, alguns critérios deveriam ser respeitados para que estes mesmos dados participassem da amostra final.

A seleção final utilizou como critérios de exclusão da amostra os mesmos que foram adotados na pesquisa original de BERGER e OFEK que são: faturamento, problema de validação entre os bancos de dados, valores extremos, LAJIR negativo e empresas com setores financeiros.

A seguir são explicados cada um deles e apresentados o número de exclusões realizadas. 


\section{IV.1.2.1. FATURAMENTO}

O valor mínimo que a UEN deveria apresentar dentro de cada ano era de US\$ 20 milhões. Aquelas empresas que apresentaram ao menos uma vez o valor menor que este estipulado, foram eliminados. Não houve nenhum critério que reconsiderasse a reinclusão destes dados. Uma vez identificada as vendas líquidas menores que este valor, excluise tanto a UEN como todas as empresas que apresentavam o mesmo parental group. Adotando-se estes critérios, foram excluídas 61 empresas da amostra.

Vale ressaltar que para todos os demais critérios também eliminou-se todos as UEN da empresa que apresentava ao menos um item em desacordo com as exigências. Também manteve-se a impossibilidade de reconsideração da inclusão na amostra.

\section{IV.1.2.2. PROBLEMAS DE VALIDAÇÃO}

A fim de confirmar os dados apresentados pelo banco de dados CIS, utilizou-se também o banco de dados da Compustat. Muito embora o primeiro tenha sido utilizado como base de coleta dos dados, o segundo banco de dados foi utilizado para conferência dos dados utilizados no que diz respeito a vendas, ativos, ativos e quantidade de UEN. Àquelas empresas que apresentaram variações entre $-5 \%$ e $+5 \%$, foram excluídos da amostra final. A eliminação por este critério atingiu 101 empresas.

\section{IV.1.2.3. LAJIR NEGATIVO}

Conforme apresentado na Metodologia de Pesquisa, quando o múltiplo de LAJIR apresentou valores negativos, adicionou-se o valor da depreciação da UEN ao mesmo. Se mesmo assim o valor ainda manteve-se negativo, excluiu-se a empresa da amostra preliminar pois 0 
modelo do multiplicador não atribui valor negativo às empresas com lucro negativo. A exclusão devido ao LAJIR + depreciação serem menores que zero atingiu 19 empresas.

\section{IV.1.2.4. EMPRESAS COM SETOR FINANCEIRO}

Para que as empresas pertencessem a amostra preliminar, elas não poderiam possuir UEN na indústria de serviços financeiros (SIC entre 6000 e 6999). Como já foi explicado na Metodologia de Pesquisa, empresas com UEN na indústria de serviços financeiros foram eliminadas das considerações pois os métodos de valorização utilizados neste estudo para estas empresas são problemáticos. Especificamente, muitas empresas da indústria de serviços financeiros não possuem informações disponíveis de lucro líquido antes dos juros e imposto de renda dado que estes ganhos não são significativos para estas empresas. A eliminação de empresas por este critério atingiu 12 empresas, a menor exclusão dentre os cinco.

\section{IV.1.2.5. VALORES EXTREMOS}

Conforme foi descrito na Metodologia de Pesquisa, os valores extremos foram excluídos da análise. O extremo é definido para todos os três multiplicadores como sendo o logaritmo natural da razão entre o valor real e o valor atribuído acima de +1,386 ou abaixo de -1,386 (isto é, valores reais mais que quatro vezes do valor atribuído, ou menores que um quarto). Através deste critério, foram excluídas 23 empresas. Esta exclusão só foi possível realizar após a seleção da amostra preliminar. Isto significa que os dados eliminados por este critério atenderam a todos os demais pois estavam contidos na amostra preliminar. Com a exclusão dos dados devido a este critério chegou-se na amostra final onde basearam-se as análises realizadas. 


\section{IV.1.3. QUANTIDADE DE EMPRESAS}

Com a exclusão das empresas da amostra preliminar, chegou-se então à amostra final utilizada para a análise deste estudo. Ao todo, foram excluídas 216 empresas da amostra preliminar o que resultou numa amostra final de 476 empresas. Estas empresas geraram 10.877 observações, das quais 9.389 eram de empresas com várias UEN. Das observações com várias UEN, 2.956 eram com duas UEN, 3.189 eram com três UEN, 2.212 eram de quatro UEN e 1.032 eram com cinco ou mais UEN. A seguir, apresenta-se o resumo das empresas eliminadas da amostras preliminar identificadas por motivo de exclusão (Vendas, LAJIR + Depreciação Negativo, Setor Financeiro, Validação do Banco de Dados e Valores Extremos) e quantidade de UEN que apresentavam em 1999.

\begin{tabular}{l|c|c|c|c|c|c}
\hline \multicolumn{1}{c|}{ No. de UEN } & $\mathbf{1}$ & $\mathbf{2}$ & $\mathbf{3}$ & $\mathbf{4}$ & $\mathbf{+ 5}$ & $\begin{array}{c}\text { Total de } \\
\text { Exclusões }\end{array}$ \\
\hline Vendas & 25 & 23 & 11 & 2 & 0 & $\mathbf{6 1}$ \\
\hline LAJIR +D Negativo & 7 & 2 & 9 & 1 & 0 & $\mathbf{1 9}$ \\
\hline Setor financeiro & 0 & 0 & 2 & 3 & 7 & $\mathbf{1 2}$ \\
\hline Validação & 3 & 7 & 18 & 29 & 44 & $\mathbf{1 0 1}$ \\
\hline Extremos & 0 & 4 & 2 & 8 & 9 & $\mathbf{2 3}$ \\
\hline Total por UEN & $\mathbf{3 5}$ & $\mathbf{3 6}$ & $\mathbf{4 2}$ & $\mathbf{4 3}$ & $\mathbf{6 0}$ & $\mathbf{2 1 6}$ \\
\hline
\end{tabular}

TABELA 11 - NÚMERO DE EMPRESAS ELIMINADAS DA AMOSTRA PRELIMINAR

Analisando a tabela acima, nota-se que o critério que mais eliminou empresas da amostra preliminar foi a validação do banco de dados que representou 46,7\% das eliminações. Já o critério que menos eliminou empresas foi a classificação de UEN dentro da indústria de serviços financeiros. 
Outra análise que se pode fazer desta mesma tabela é pela quantidade de UEN que estas empresas eliminadas possuíam. A maior eliminação ocorreu em empresas que possuíam 5 ou mais UEN enquanto que a menor eliminação ficou com as empresas que apresentavam uma única UEN. Nestas empresas, não houve nenhuma eliminação por motivos relacionados à UEN em setor financeiro e devido a valores extremos.

A não-eliminação de empresas com uma única UEN da amostra preliminar devido a classificação da unidade em setor financeiro já era esperada pois a seleção da amostra preliminar exigia que as empresas apresentassem UEN no subgrupo 3661. Obviamente que se a empresa com uma UEN apresentasse classificação SIC entre 6000 e 6999, ela não poderia apresentar classificação no subgrupo 3661 .

$\mathrm{Na}$ análise cruzada entre critérios de eliminação e quantidade de UEN, pode-se notar que o critério que mais eliminou (validação) apresentou concentração em empresas com cinco ou mais UEN $(20,4 \%)$, o que intuitivamente faz sentido pois quanto maior o número de unidades, mais provável de se obter divergências nas informações.

A seguir, apresenta-se as empresas que compuseram a base de dados para análise nesta pesquisa identificadas pela quantidade de UEN que continham no final do ano de 1999: 


\begin{tabular}{l|c|c|c|c|c|c|c}
\hline $\begin{array}{c}\text { Quantidade de } \\
\text { UEN }\end{array}$ & $\mathbf{1}$ & $\mathbf{2}$ & $\mathbf{3}$ & $\mathbf{4}$ & $\mathbf{5}$ ou & Tota & $\%$ \\
$\mathbf{+}$ & $\mathbf{+}$ & $\mathbf{I}$ & \\
\hline Telefonia Fixa & 28 & 26 & 29 & 32 & 25 & $\mathbf{1 4 0}$ & 29,4 \\
\hline Telefonia Móvel & 31 & 27 & 26 & 21 & 29 & $\mathbf{1 3 4}$ & 28,2 \\
\hline Infra-estrutura & 10 & 14 & 9 & 7 & 14 & $\mathbf{5 4}$ & 11,3 \\
\hline Comunicação de & 7 & 11 & 13 & 12 & 10 & $\mathbf{5 3}$ & 11,1 \\
Dados & & & & & & & \\
\hline Transmissão & 7 & 9 & 7 & 8 & 3 & $\mathbf{3 4}$ & 7,1 \\
\hline Outros & 13 & 14 & 15 & 10 & 9 & $\mathbf{6 1}$ & 12,9 \\
\hline TOTAL & $\mathbf{9 6}$ & $\mathbf{1 0 1}$ & $\mathbf{9 9}$ & $\mathbf{9 0}$ & $\mathbf{9 0}$ & $\mathbf{4 7 6}$ & 100 \\
\hline Percentual & 20,2 & 21,2 & 20,8 & 18,9 & 18,9 & 100 & \\
\hline
\end{tabular}

TABELA 12 - AMOSTRA FINAL POR QUANTIDADE DE UEN E SEGMENTOS

Analisando a tabela anterior pela quantidade de UEN, nota-se que há um equilíbrio na distribuição dos mesmos dentro da amostra final. Empresas com 4 e com 5 ou mais UEN apresentam a mesma quantidade de dados amostrais. As empresas com 2 UEN são as que possuem maioria muito embora a diferença seja muito pequena em relação às empresas com 3 UEN (99 empresas) e com uma única UEN (96 empresas).

A análise pela composição das empresas por UEN revela que as empresas que apresentam UEN em Telefonia Fixa e Telefonia Móvel são a maioria representando juntas $57,6 \%$ da amostra final. As empresas com UEN em Telefonia Fixa apresentam-se em maior número (140 empresas) enquanto que as empresas classificadas dentro do grupo Transmissão apresentam o menor número de empresas dentro da amostra (34 empresas). 
O maior número de empresas em valores absolutos dentro de um determinado segmento é o que consta no segmento Telefonia Fixa com 4 UEN: 32 empresas. Já a que apresenta o menor número de empresas dentro de um segmento específico é o segmento de Transmissão com 5 ou mais UEN: 3 empresas.

A análise por segmento e quantidade de UEN poderia gerar um questionamento: e se houver, dentro de um determinado segmento identificado, empresas que apresentem a quantidade de UEN maior ou igual a 2? Qual será o critério de utilização dos múltiplos dado que eles se baseiam em valores de empresas com uma única UEN? Caso esta situação extrema ocorresse, não teria efeito sobre a pesquisa pois a verificação da variação do valor não está sendo feita sob a consideração das UEN mais sim sobre o subgrupo 3661 do SIC.

\section{IV.2. CARACTERÍSTICAS DA AMOSTRA DO PONTO DE VISTA DOS SEGMENTOS}

O objetivo desta seção é apresentar as características da amostra final composta por 476 empresas de acordo com cada um dos múltiplos utilizados na pesquisa. Para tanto, apresenta-se uma tabela mostrando os dados estatísticos calculados para o período de 1990 a 1999 e um gráfico mostrando a evolução de cada múltiplo. Para facilitar a análise e entendimento, adotou-se para estes gráficos o ano de 1990 como anobase (Base 100) e assim, os demais anos apresentam-se em função desta base. Logo, a análise dos números índices criados ano a ano por segmento permite avaliar diretamente a evolução dos múltiplos.

As medidas de tendência central (média e mediana) e o desvio-padrão apresentados referem-se aos valores anuais totais e não aos valores por empresa.

O capital total é a soma do valor contábil dos empréstimos e o valor de mercado do patrimônio líquido, conforme já apresentado anteriormente. 
A alavancagem da indústria é a diferença entre a alavancagem atual da empresa, definida como a razão entre os empréstimos totais e os ativos totais, e seu valor imputado de alavancagem. A alavancagem imputada de cada UEN da empresa é calculado como sendo os ativos da UEN multiplicado pela razão mediana da indústria entre empréstimos de terceiros e ativos totais. O indicador Impostos ajustados a indústria é a diferença entre os impostos atualmente pagos a indústria e seus impostos imputados que foi calculado através do LAJIR da UEN multiplicado pela razão mediana da indústria de pagamento de impostos pelo LAJIR.

A tabela 13 descreve as empresas com uma e várias UEN, assim como as diferenças entre os grupos. Devido ao skewness da distribuição, enfatizou-se mais a mediana do que a média. Pela mediana, conclui-se que as empresa com várias UEN têm duas unidades aproximadamente, duas vezes o total de capital do que as empresas com uma UEN. Suas medianas de índice de alavancagem ajustada da indústria (valor contábil dos empréstimos sobre o total de ativos) são 2,9\% maior que as empresas focadas em uma única UEN, o que é consistente com UEN de empresas diversificadas quem tomam mais empréstimos; e suas medianas de impostos não diferem das empresas com uma UEN, o que é inconsistente com os benefícios fiscais da diversificação.

\begin{tabular}{|c|c|c|c|c|c|c|c|c|}
\hline \multirow{2}{*}{$\begin{array}{l}\text { Característica da amostra } \\
\text { ao nivel da empresa }\end{array}$} & \multicolumn{3}{|c|}{ UM SEGMENTO } & \multicolumn{3}{|c|}{ VÁRIOS SEGMENTOS } & \multicolumn{2}{|c|}{ Diferença } \\
\hline & Média & Mediana & $D P$ & Média & Mediana & $D P$ & Média & Mediana \\
\hline Número de segmentos & 1,0000 & 1,0000 & & 2,2553 & 2,0000 & 1,1280 & 1,2553 & 1,0000 \\
\hline Capital Total (US\$ milhões) & 27 & 206 & 44 & 68 & 422 & 4.734 & 41 & 216 \\
\hline Total de em & 0,2570 & 0,2780 & 0,2170 & 0,2900 & 0,3050 & 0,1910 & 0,0330 & 0,0270 \\
\hline Alavancagem da indústria & - & 0,0270 & 0,1980 & 0,0290 & 0,0410 & 0,1930 & 0,0290 & 0,0140 \\
\hline Impostos/Vendas & 0,0160 & 0,0270 & 0,0440 & 0,0170 & 0,0240 & 0,0390 & 0,0010 & $(0,0030)$ \\
\hline Impostos ajustados a indústria & - & $(0,0010)$ & 0,0230 & - & $(0,0020)$ & 0,0150 & - & $(0,0010)$ \\
\hline Observaçốes & & 2.896 & & & 1.385 & & & \\
\hline
\end{tabular}

TABELA 13 - ESTATÍSTICA DESCRITIVA DA AMOSTRA DE EMPRESAS 
A linha UEN com Fluxo de Caixa Negativo foi calculada considerando o valor 1 se a unidade apresentava fluxo de caixa negativo e 0 para 0 fluxo de caixa positivo maior ou igual a zero.

\begin{tabular}{l|r|r|r|r|r|r|r|r}
\hline \multicolumn{1}{c|}{ Característica da amostra } & \multicolumn{3}{|c|}{ UM SEGMENTO } & \multicolumn{3}{c|}{ VÁRIOS SEGMENTOS } & \multicolumn{2}{c}{ Diferença } \\
\multicolumn{1}{c|}{ ao nível do segmento } & Média & Mediana & DP & Média & Mediana & DP & Média & Mediana \\
\hline \hline Vendas (US\$ milhổes) & 103 & 135 & 67 & 224 & 260 & 68 & 121 & 126 \\
Ativos (US\$ milhổes) & 565 & 728 & 429 & 1.246 & 1.427 & 432 & 681 & 700 \\
Investimento Capital/ Vendas & 0,0440 & 0,0870 & 0,0136 & 0,0450 & 0,1010 & 0,1760 & 0,0010 & 0,0140 \\
Fluxo de Caixa Negativo & - & 0,0820 & 0,0274 & - & 0,0900 & 0,2860 & - & 0,0080 \\
\hline Observaçổes & \multicolumn{3}{|c|}{2.896} & \multicolumn{3}{c|}{1.385} & \multicolumn{3}{c}{} \\
\hline
\end{tabular}

\section{TABELA 14- ESTATíSTICA DESCRITIVA DA AMOSTRA DE UEN}

As características dos níveis das UEN da tabela 14 são baseadas nos dados das próprias UEN. UEN de empresas diversificadas tendem ser menores que as empresas focadas, muito embora esta diferença seja devido em parte à alocação incompleta de ativos para empresas diversificadas em suas unidades. As UEN das empresas diversificadas diferem de alguma forma das empresas focadas nos seus níveis de investimento e na probabilidade de terem fluxo de caixa negativo. $O$ nível do investimento, medido pela razão do investimento de capital pelas vendas, é maior para UEN de empresas diversificadas, muito embora somente a diferença na média seja significante. Adicionalmente, $9 \%$ das UEN diversificadas apresentam fluxo de caixa negativo contra $8,2 \%$ das empresas com uma única UEN. A maior presença do fluxo de caixa negativo entre as UEN de empresas diversificadas é consistente com a afirmativa de que empresas diversificadas mantêm divisões com desempenhos abaixo do que elas teriam se fossem conduzidas isoladamente.

\section{IV.2.1. VENDAS}

A seguir, apresenta-se a tabela contendo a média, mediana e desviopadrão das vendas durante o período de 1990 a 1999 por tipo de 
segmento. Adicionalmente, apresenta-se a participação percentual das vendas de cada segmento em relação ao total da amostra calculada através dos valores absolutos.

\begin{tabular}{l|c|c|c|c}
\hline $\begin{array}{l}\text { Em milhões dólares } \\
\text { por ano }\end{array}$ & Média & Mediana & Desvio & \% PART \\
\hline Telefonia Fixa & 18.620 & 19.763 & 3.652 & $29 \%$ \\
\hline Telefonia Móvel & 17.680 & 18.743 & 3.326 & $28 \%$ \\
\hline Infra-estrutura & 7.418 & 7.832 & 1.656 & $12 \%$ \\
\hline Comunicação de & 7.261 & 7.927 & 1.634 & $11 \%$ \\
Dados & & & & \\
\hline Transmissão & 4.560 & 4.803 & 890 & $7 \%$ \\
\hline Outros & 7.742 & 8.364 & 1.519 & $12 \%$ \\
\hline TOTAL & $\mathbf{6 3 . 2 8 0}$ & $\mathbf{6 7 . 9 4 7}$ & $\mathbf{1 2 . 5 0 2}$ & $\mathbf{1 0 0 \%}$ \\
\hline
\end{tabular}

TABELA 15 - MÉDIA, MEDIANA, DESVIO-PADRÃO DAS VENDAS POR SEGMENTO

As 476 empresas que pertencem à amostra final apresentaram durante o período estudo um valor total de vendas médias em torno de US\$63,3 bilhões de dólares, o que representa um faturamento líquido por empresa próximo a US\$133 milhões por ano. A mediana foi calculada com o objetivo de se verificar a existência de dados extremos na amostra. O resultado obtido com a mediana é condizente com os procedimentos de exclusão dos valores extremos.

Dos segmentos que compõem esta amostra, o segmento Telefonia Fixa apresentou o maior volume médio de vendas seguido do segmento de Telefonia Móvel. Novamente, estes dois segmentos representam mais que a metade da amostra em volume de vendas.

Comparando a composição percentual das vendas com a participação no número de empresas por segmento, verifica-se que a mesma ordem se mantém. Este resultado era provável de se ocorrer dado que a média 
e mediana se mantiveram próximas pois se segmentos com menos quantidade de empresas apresentasse uma maior volume médio de vendas, poder-se-ia ter uma concentração de valores extremos. Certamente que esta situação dependeria da volume de vendas.

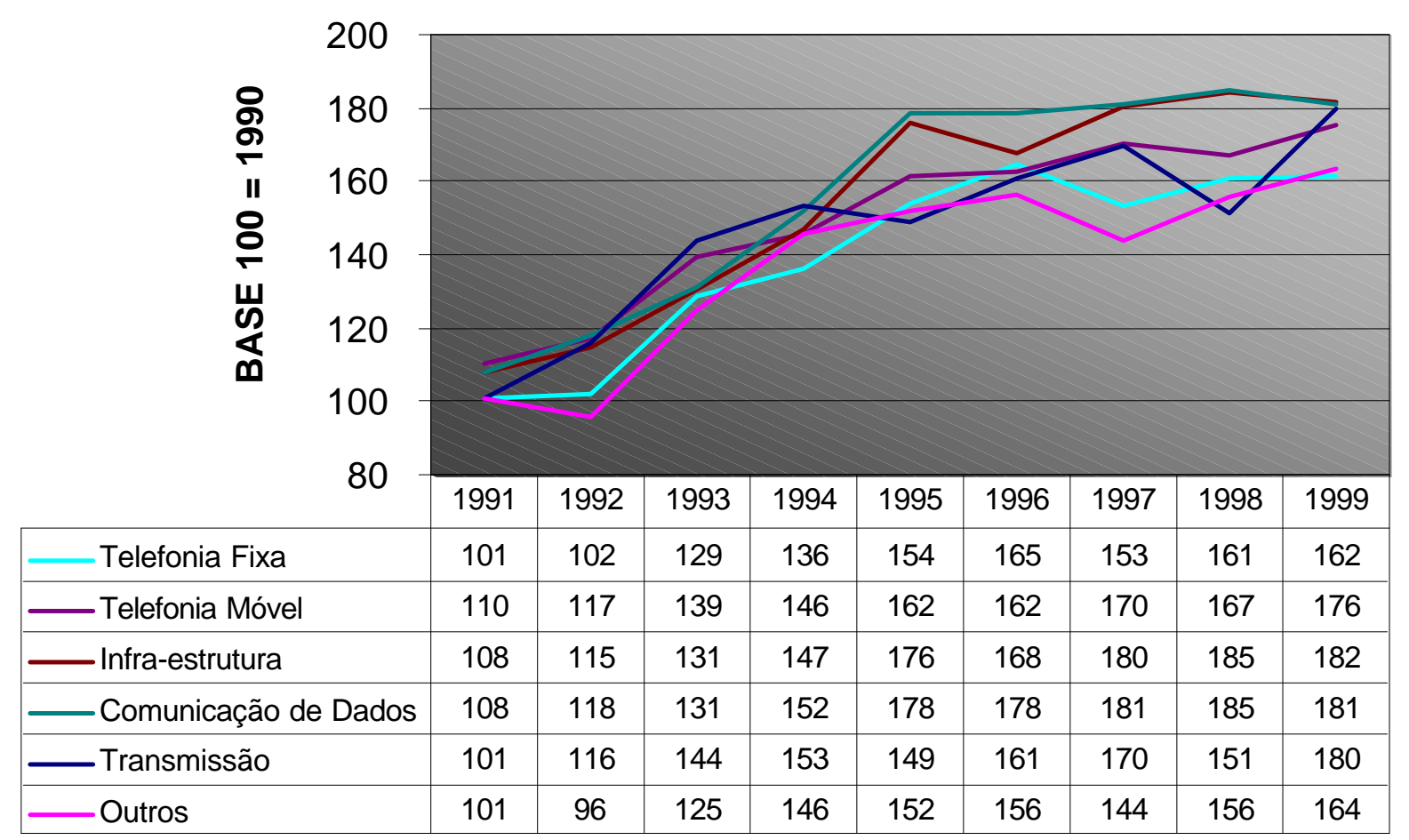

GRÁFICO 3 - EVOLUÇÃO DAS VENDAS MÉDIAS POR SEGMENTO

Numa primeira análise do gráfico, observa-se que todos os segmentos apresentaram um crescimento nas vendas médias durante o período estudado. É interessante notar que os anos de 1991 e 1992 apresentaram um crescimento menor que os anos seguintes. Aliás, apenas o segmento classificado como Outros apresentou queda na receita em relação ao ano de 1990. Esta queda ocorreu em 1992, ano que a Telefonia Fixa apresentou também um crescimento pífio em relação aos demais segmentos. Porém, em 1993 este segmento apresenta um grande salto, acompanhando a partir dai os demais crescimentos. Uma possível razão para evolução do segmento de Telefonia Fixa a partir de 1993 deve-se ao fato do crescimento dos acessos a Internet que é fornecido através dos equipamentos do 
segmento de Comunicação de Dados. Como o mercado de voz de Telefonia Fixa encontrava-se saturado (reflexo na evolução das vendas no início da década de 90), com a expansão da Internet, novas linhas foram adquiridas para prover acesso e isto demandou novos investimentos por parte das operadoras de telefonia. Agora, as vendas passaram a ser incrementadas pelo acesso discado a Internet e não somente a voz.

Embora o segmento de Infra-estrutura seja o que mais cresceu no período (82\%), este segmento juntamente com os segmentos de Outros e Comunicação de Dados apresentaram queda em relação ao ano anterior. Já o segmento de Telefonia Fixa dá sinais de estabilização no final da década após a queda de 12\% de 1996 para 1997. O segmento de Telefonia Móvel que apresentou um crescimento rápido até 1995, mantém o seu crescimento mas em um nível bem menor que no início da década.

Para o setor de Transmissão, o ano de 1998 representou um queda nas vendas mas que foi recuperada no ano seguinte. Uma possibilidade para explicar a retração neste segmento durante o ano de 1998 é que o mercado necessitou mais da infra-estrutura de comunicação de dados, que apresentou crescimento, do que novos acessos. No ano seguinte, em 1999, com a infra-estrutura de Comunicação de Dados já montada, partiu-se para a Transmissão dos mesmos, o que ocasionou um redirecionamento dos investimentos do segmento de Comunicação de Dados para o segmento de Transmissão.

\section{IV.2.2. ATIVOS}

Baseado na classificação dos segmentos pelo volume de vendas, montou-se a tabela a seguir onde consta a média, a mediana e o desviopadrão dos ativos dos segmentos em milhões de dólares. 


\begin{tabular}{l|r|r|r|r}
\hline $\begin{array}{l}\text { Em milhões dólares } \\
\text { por ano }\end{array}$ & Média & Mediana & Desvio & \multicolumn{1}{c}{ \% PART } \\
\hline Telefonia Fixa & 105.547 & 103.044 & 19.411 & $30 \%$ \\
\hline Telefonia Móvel & 101.566 & 101.858 & 20.242 & $28 \%$ \\
\hline Infra-estrutura & 41.311 & 42.408 & 8.463 & $12 \%$ \\
\hline Comunicação de & 38.609 & 37.851 & 7.195 & $11 \%$ \\
Dados & & & & $7 \%$ \\
\hline Transmissão & 25.393 & 25.682 & 5.770 & $13 \%$ \\
\hline Outros & 44.994 & 45.682 & 7.629 & $\mathbf{1 0 0 \%}$ \\
\hline TOTAL & $\mathbf{3 5 7 . 4 2 0}$ & $\mathbf{3 5 4 . 2 3 1}$ & $\mathbf{6 6 . 7 9 9}$ & \\
\hline
\end{tabular}

TABELA 16 - MÉDIA, MEDIANA, DESVIO-PADRÃO dOS ATIVOS POR SEGMENTO

Duas considerações podem ser feitas com relação a tabela das médias das Vendas: a primeira se refere à aproximação da média e da mediana para os Ativos e a outra consideração se refere à manutenção da ordem de participação das UEN agora por ativo. A mesma ordem estabelecida através do volume de vendas, praticamente se mantém em ativos. A única exceção é o segmento Outros que em vendas estava empatado com o segmento Infra-estrutura e agora apresenta-se em torno de $1 \%$ acima.

O segmento de Telefonia Móvel é o que apresenta o maior desviopadrão, ou seja, é o que apresenta a maior variação durante o período estudado. Este resultado é condizente com a aproximação da mediana e da média.

As empresas pertencentes a esta amostra apresentam em média ativos totais em torno de US\$750 milhões. Isto significa que são empresas que geram em média $17 \%$ dos seus ativos em vendas.

A seguir, apresenta-se a evolução dos ativos por segmentos: 


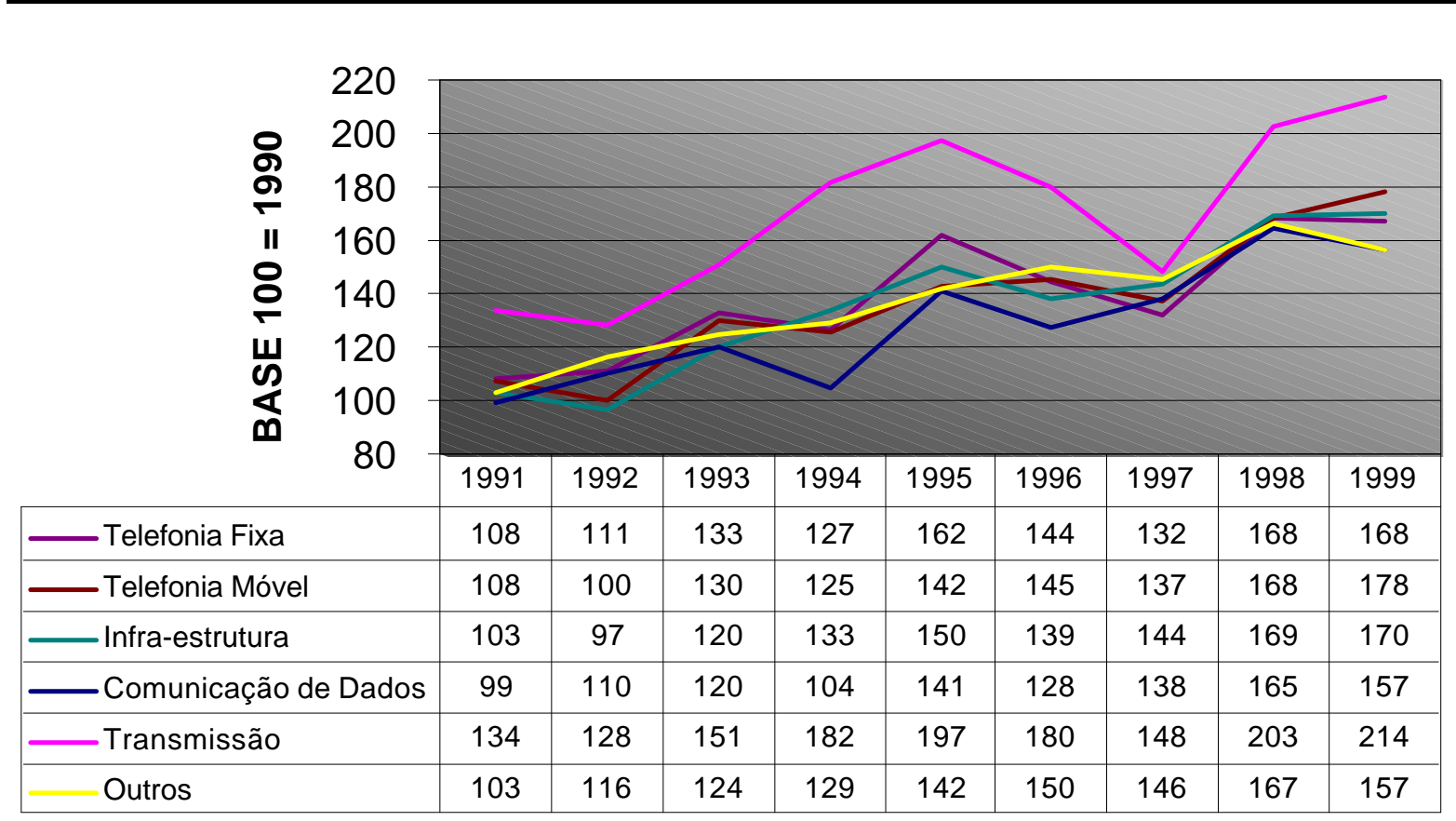

GRÁFICO 4 - EVOLUÇÃO DOS ATIVOS MÉDIOS POR SEGMENTO

A análise gráfica mostra que o segmento Transmissão foi o que mais cresceu em termos de ativos em relação aos demais segmentos. Muito embora apresente uma queda acentuada no ano de 1997, este foi segmento que mais cresceu na década de 90. Em 1999, os seus ativos mais que dobraram enquanto que os segmentos Outros e Comunicação de Dados atingiram um crescimento em torno de 57\% em relação a 1990.

Os segmentos da Telefonia que vinha despertando atenção pelo número de empresas na amostra e pelo volume médio de vendas, neste item perdem a liderança. O segmento de Telefonia Fixa apresenta um crescimento zero em 1999 e o segmento de Infra-estrutura também está próximo deste crescimento. Com exceção do segmento Outros, o segmento de Comunicação de Dados foi o único que reduziu o valor médio dos seus ativos no último ano. Aliás, este segmento está entre aqueles que apresentam os menores crescimentos durante o período analisado. Já o segmento de Infra-estrutura apresenta reduções nos 
ativos médios comparado com o nível de 1990 em dois anos, intercalados por períodos de 3 anos de crescimento.

Comparando a evolução das vendas médias do segmento Transmissão com os ativos médios, nota-se que a queda brusca em 1997 dos ativos se reflete nas vendas médias no ano seguinte. Como estas indústrias trabalham sob encomendas, a redução nos seus ativos podem indicar uma redução na capacidade de produção o que implica numa redução de vendas no período seguinte pois não poderá atender a mesma demanda. Neste ponto, não se pode dizer nada a respeito sobre quem é a causa e quem é o efeito, ou seja, a pergunta que fica é: a empresa reduziu os seus ativos prevendo uma redução nas vendas do ano seguinte ou em função da redução dos seus ativos, reduziu-se as vendas pois não havia produtos disponíveis para venda?

\section{IV.2.3. LAJIR}

O último múltiplo a ser analisado é o LAJIR. Para esta análise, não se ajustaram os valores negativos com a depreciação pois esta parte do trabalho tem o objetivo de verificar as características dos dados amostrais e não a variação no valor da empresa.

Da mesmo forma que os múltiplos anteriores, apresenta-se o valor médio, mediana e desvio-padrão por segmento juntamente com a participação de cada segmento no valor total do amostra. Em seguida, apresenta-se o gráfico com a evolução anual de cada segmento. 


\begin{tabular}{l|r|r|r|r}
\hline $\begin{array}{l}\text { Em milhões dólares } \\
\text { por ano }\end{array}$ & Média & Mediana & Desvio & \multicolumn{1}{c}{ \% PART } \\
\hline Telefonia Fixa & 3.216 & 2.800 & 1.914 & $29 \%$ \\
\hline Telefonia Móvel & 3.010 & 2.475 & 1.853 & $28 \%$ \\
\hline Infra-estrutura & 1.366 & 1.047 & 858 & $12 \%$ \\
\hline Comunicação de & 1.332 & 1.000 & 841 & $11 \%$ \\
Dados & & & & $7 \%$ \\
\hline Transmissão & 852 & 698 & 533 & $12 \%$ \\
\hline Outros & 1.477 & 1.091 & 786 & $\mathbf{1 0 0 \%}$ \\
\hline TOTAL & $\mathbf{1 1 . 2 5 3}$ & $\mathbf{8 . 6 9 0}$ & $\mathbf{6 . 6 0 0}$ & $7 \%$ \\
\hline
\end{tabular}

TABELA 17 - MÉDIA, MEDIANA, DESVIO-PADRÃO DO LAJIR POR SEGMENTO

Coincidentemente, a participação por segmento no múltiplo de LAJIR apresenta os mesmos números que o múltiplo de Vendas. Porém, as comparações entre as médias e medianas dos dois múltiplos apresentam-se de forma distintas. Enquanto que no múltiplo de Vendas estas duas medidas de tendência central estão próximas, no múltiplo de LAJIR elas estão distantes. Como reflexo, pode-se verificar os desviospadrões produzidos por ambos. O múltiplo de LAJIR apresenta o desviopadrão muito maior que o múltiplo de Vendas, mostrando uma dispersão maior, levando conclusão que os valores de LAJIR das empresas apresentam grandes variações.

Na média, o LAJIR Total representa 17,8 \% das Vendas Totais. Muito embora este valor seja positivo, não significa que as empresas não apresentem valor negativos pois o desvio-padrão desta média é muito elevado. 
Como a média do LAJIR é maior do que a mediana para qualquer segmento, pode-se dizer que os valores extremos são valores positivos pois caso contrário, a mediana seria maior que a média.

A seguir, apresenta-se a evolução do LAJIR por segmento e por ano:

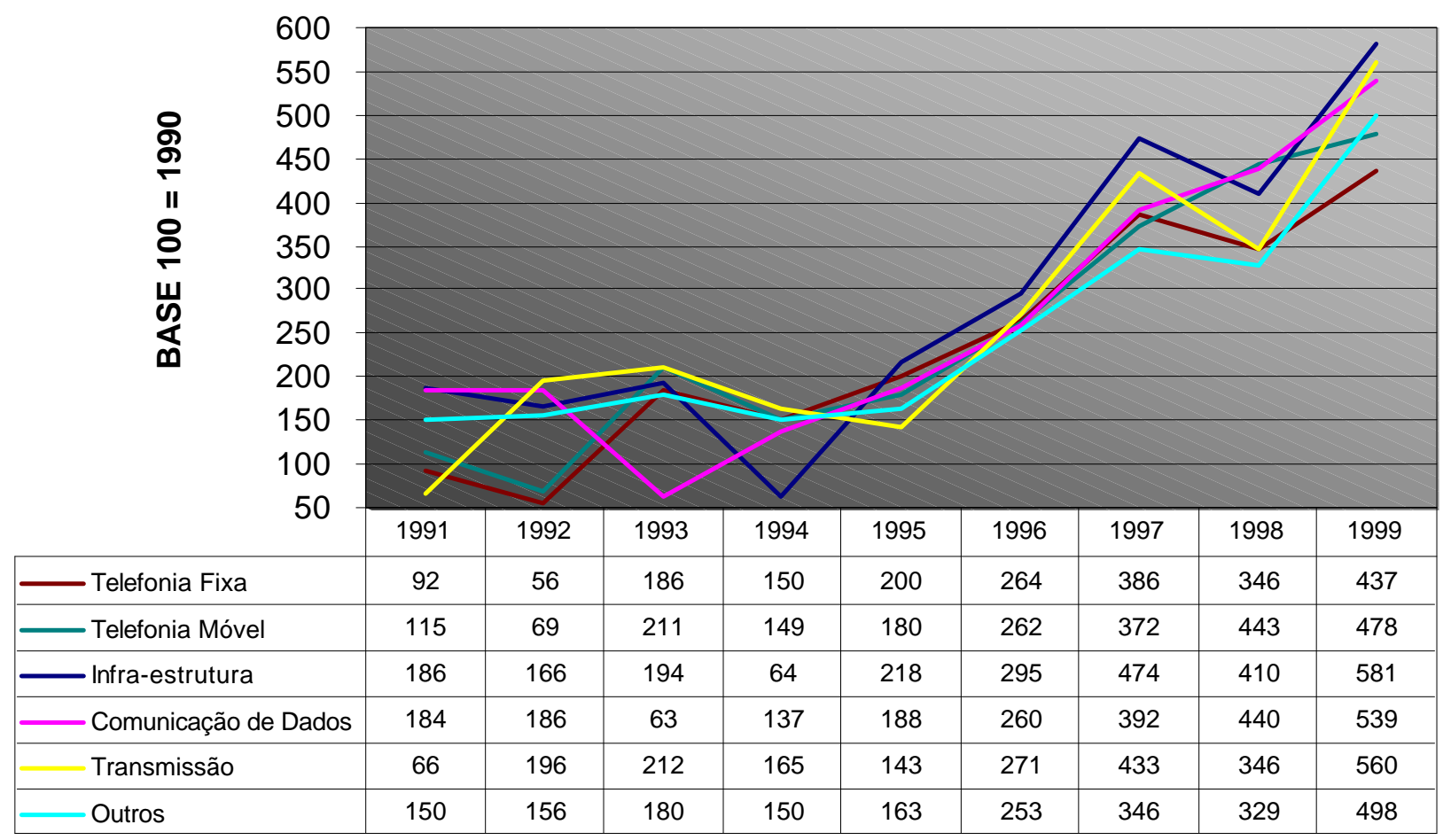

\section{GRÁFICO 5 - EVOLUÇÃO DO LAJIR MÉDIO POR SEGMENTO}

Assim como os demais múltiplos, este também apresenta uma orientação de crescimento ao longo dos anos. Todos os segmentos apresentam em 1999 no mínimo um crescimento de 4 vezes do seu valor em 1990. Porém, apesar deste crescimento, durante a década houve momentos de redução do crescimento. Os segmentos de Telefonia em 1992, o segmento Comunicação de Dados no ano de 1993 e o segmento Infra-estrutura em 1994 apresentam estas reduções acentuadas no gráfico. No final da década, o segmento de Infraestrutura foi o que apresentou o maior crescimento (4,81 vezes em relação a 1990). Na metade década de 90, apenas os segmentos de Telefonia Fixa e Infra-estrutura havia duplicado o seu crescimento, 
indicando que na segunda metade da década, o crescimento foi mais maior que na primeira metade.

Outra evolução que chama atenção é a do setor de Transmissão que apresenta o segundo maior crescimento entre os segmentos mas que apresenta dois anos com quedas acentuadas: 1995 e 1998.

\section{IV.3. CARACTERÍSTICAS DA AMOSTRA DO PONTO DE VISTO DA QUANTIDADE DE UEN}

$\mathrm{Na}$ seção anterior, verificou-se as características amostrais por tipo de segmento e sua evolução durante o período estudado. Nesta seção, são apresentadas as mesmas informações porém classificadas de acordo com a quantidade de UEN. Todos os dados são apresentados em milhões de dólares. As categorias de classificação são: 1, 2, 3, 4 e 5 ou mais UEN. Ao final de cada categoria, são apresentadas as quantidades de empresas que pertencem àquela categoria. Logicamente que estas quantidades se mantêm independente do múltiplo que estiver sendo apresentado.

A classificação por UEN se deu através da posição de 1999. Neste ano, a amostra era composta por 1.405 UEN que pertenciam a 476 empresas distintas, ou seja, uma média de quase 3 UEN por empresa $(2,95)$.

Assim como foi dito no início da seção que introduzia as características da amostra do ponto de vista dos segmentos, as medidas de tendência central (média e mediana) e o desvio-padrão apresentados referem-se aos valores totais anuais e não aos valores por empresa.

\section{IV.3.1. VENDAS}

A tabela que apresenta as características da amostra classificada por quantidade de UEN referente ao múltiplo de Vendas encontra-se a seguir: 


\begin{tabular}{l|r|r|r|r}
\hline Vendas & Média & $\begin{array}{c}\text { Median } \\
\mathbf{a}\end{array}$ & Desvio & Qtidade \\
\hline 1 UEN & 14.943 & 15.370 & 2.823 & 96 \\
\hline 2 UEN & 12.877 & 13.204 & 2.503 & 101 \\
\hline 3 UEN & 10.398 & 11.093 & 2.202 & 99 \\
\hline 4 UEN & 11.556 & 12.134 & 2.432 & 90 \\
\hline 5 OU + UEN & 13.506 & 14.210 & 2.907 & 90 \\
\hline
\end{tabular}

TABELA 18 - MÉDIA, MEDIANA E DESVIO-PADRÃO DE VENDAS POR QUANTIDADE DE UEN

Conforme já havia sido mostrado anteriormente, o grupo de 2 UEN é o que apresenta o maior número de dados amostrais, seguido do grupo com 1 UEN. Porém, em relação às vendas médias por quantidade de UEN, o grupo de 2 UEN apresenta valores menores que o grupo de 1 UEN tanto na média como na mediana.

Outra análise interessante revela-se entre a comparação do grupo de 4 UEN o grupo de 5 ou mais UEN. Embora a quantidade amostral seja a mesma (90 empresas), a soma das vendas das empresas que possuem 5 ou mais UEN são superiores ao grupo de empresas que apresentam 4 UEN. Note que em nenhuma categoria, a mediana é menor que a média.

Para se analisar a evolução da diversificação, montou-se também gráficos tomando o ano de 1990 como ano-base (Base 100 = 1990). A seguir é apresentado o gráfico com a evolução do crescimento das vendas durante o período estudado. 


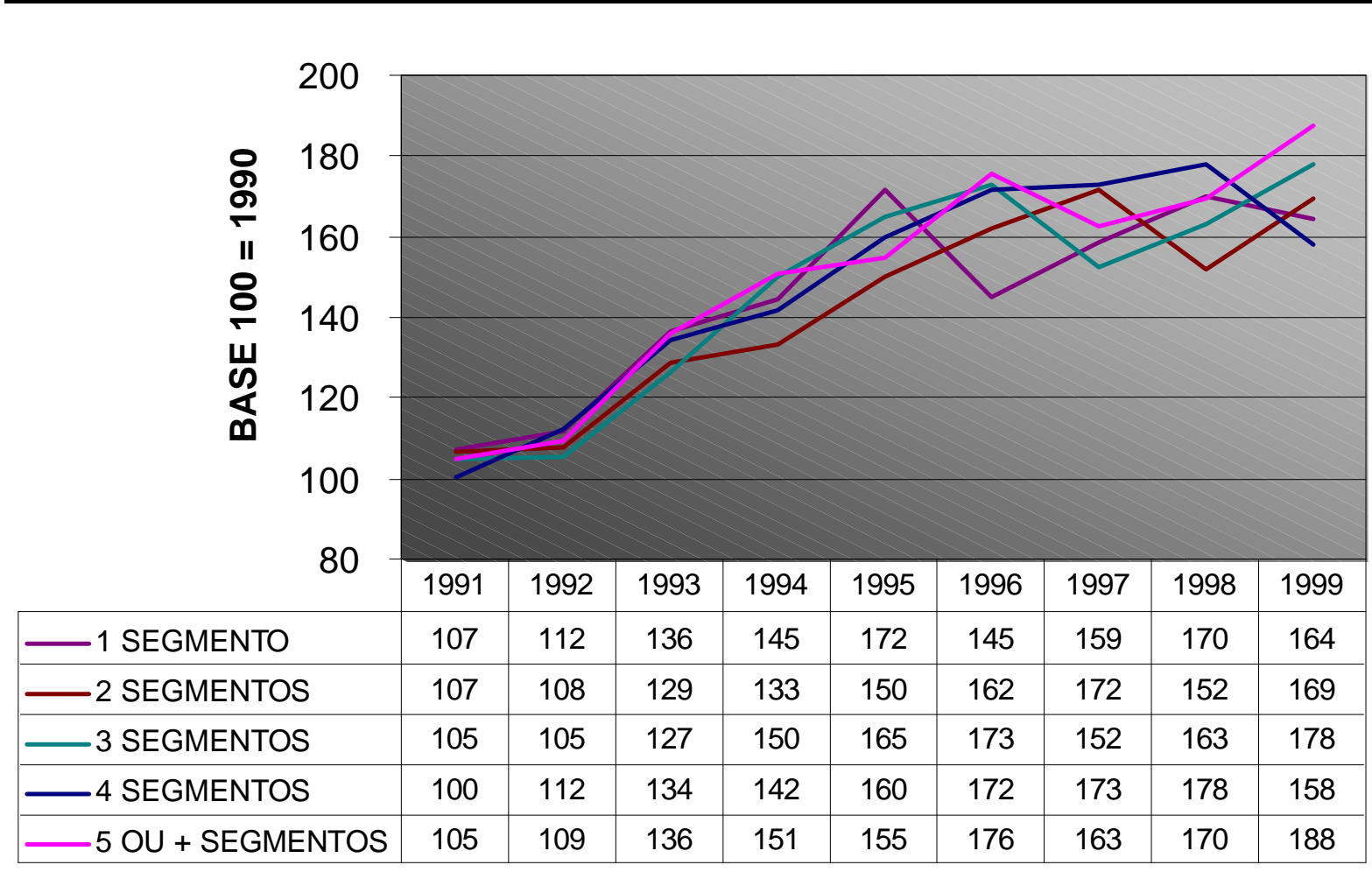

\section{GRÁFICO 6 - EVOLUÇÃO DAS VENDAS POR QUANTIDADE DE UEN}

O grupo de UEN que apresentou o maior crescimento foi o grupo que contém 5 ou mais UEN. O grupo de 4 UEN apresenta o maior crescimento acumulado até 1998 mas cai em 1999. Excetuando-se este grupo, pode-se dizer que a velocidade de crescimento de vendas reduziu em 1999 conforme reduziu-se a quantidade de UEN na empresa. Empresas com 1 UEN cresceram 64\% em relação a 1990 enquanto que empresas com 2 UEN cresceram $69 \%$ e empresas com 3 UEN cresceram $78 \%$ além é claro de empresas com 5 ou mais UEN que cresceram 88\% em relação às vendas de 1990. Nenhum grupo apresentou crescimento em todos os períodos. O grupo que apresentou o maior número de crescimentos consecutivos durante os anos analisados foi o grupo de empresas com 4 UEN (entre 1991 e 1998).

\section{IV.3.2. ATIVOS}

A tabela que apresenta as características da amostra classificada por quantidade de UEN referente ao múltiplo de Ativos encontra-se a seguir: 


\begin{tabular}{l|r|r|r|r}
\hline Ativos & Média & $\begin{array}{c}\text { Median } \\
\text { a }\end{array}$ & Desvio & Qtidade \\
\hline 1 SEGMENTO & 84.055 & 79.741 & 17.485 & 96 \\
\hline 2 UEN & 76.257 & 75.464 & 17.058 & 101 \\
\hline 3 UEN & 58.399 & 61.201 & 9.767 & 99 \\
\hline 4 UEN & 65.976 & 67.793 & 12.673 & 90 \\
\hline 5 OU + UEN & 72.734 & 72.933 & 12.199 & 90 \\
\hline
\end{tabular}

TABELA 19 - MÉDIA, MEDIANA E DESVIO-PADRÃO DE ATIVOS POR QUANTIDADE DE UEN

Assim como ocorre a média de vendas, a média de ativos de empresas com 1 UEN é maior que a média de ativos de empresas com 2 UEN embora a amostra do segundo grupo seja menor que a amostra do primeiro grupo. O grupo de 3 UEN é o que apresenta o menor valor médio de ativo por empresa (US\$ 590 milhões).

A seguir apresenta-se a evolução do crescimento dos ativos agrupados por quantidade de UEN: 


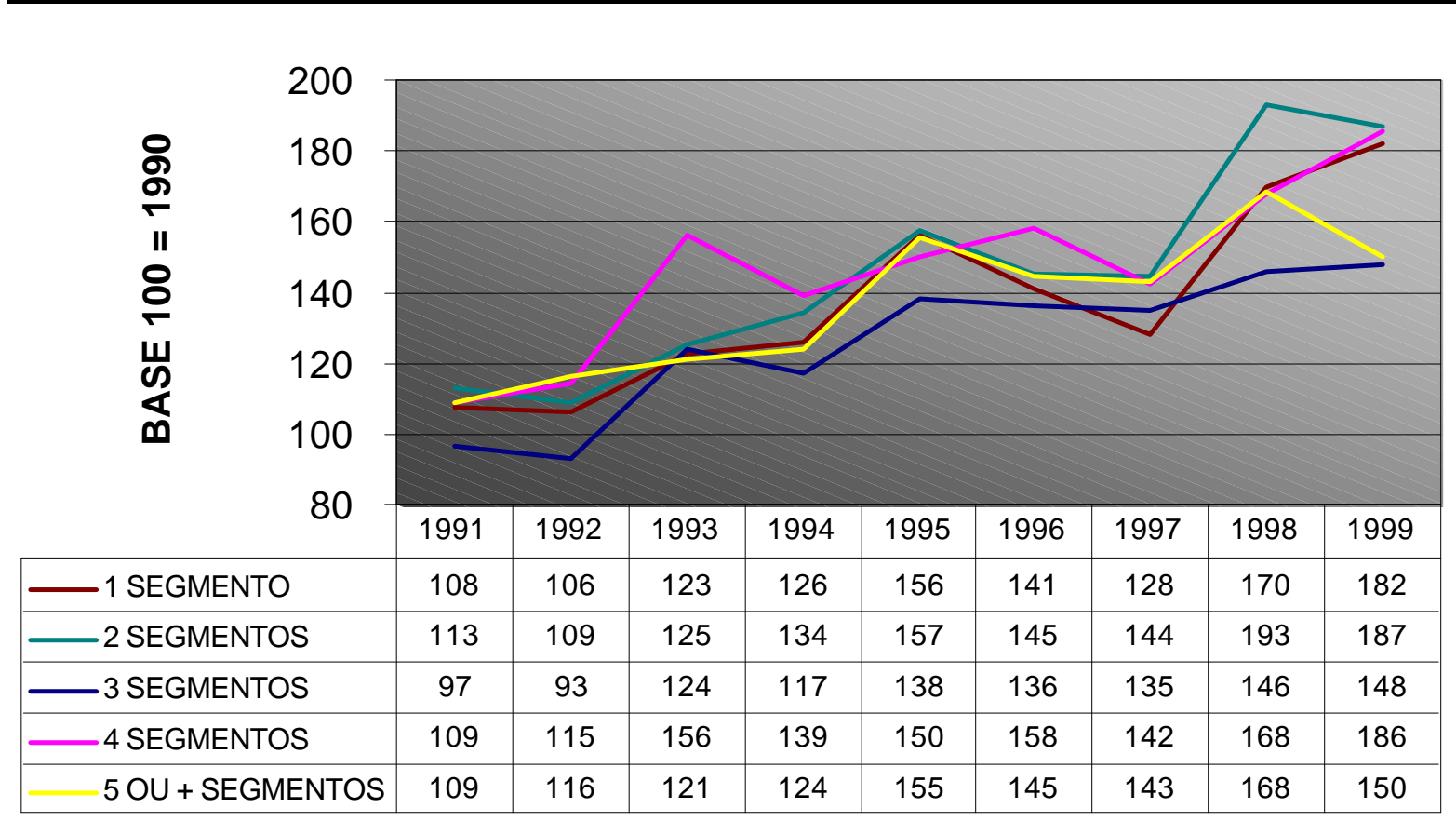

GRÁFICO 7 - EVOLUÇÃO DOS ATIVOS POR QUANTIDADE DE UEN

Pelo gráfico, pode-se dizer que o crescimento dos ativos durante este período foi muito próximo para os grupos de empresas que possuem 2 e 3 UEN. Os grupos com 3 UEN e com 5 ou mais UEN foram os que apresentaram menor crescimento. Aliás, as empresas pertencentes ao grupo com 3 UEN foram as únicas que apresentaram crescimento negativo durante os anos de 1990 e 1999. Nenhum grupo apresentou crescimentos positivos durante todos os anos. O que apresentou 0 maior período de crescimento consecutivo foi o grupo com 5 ou mais UEN durante os anos de 1991 e 1995.

\section{IV.3.3. LAJIR}

A tabela que apresenta as características da amostra classificada por quantidade de UEN referente ao múltiplo de LAJIR encontra-se a seguir: 


\begin{tabular}{l|r|r|r|r}
\hline LAJIR & Média & $\begin{array}{c}\text { Median } \\
\mathbf{a}\end{array}$ & Desvio & Qtidade \\
\hline 1UEN & 2.721 & 2.193 & 1.626 & 96 \\
\hline 2UEN & 2.396 & 1.850 & 1.482 & 101 \\
\hline 3UEN & 1.903 & 1.486 & 1.158 & 99 \\
\hline 4UEN & 2.115 & 1.623 & 1.266 & 90 \\
\hline 5 OU+UEN & 2.458 & 1.870 & 1.576 & 90 \\
\hline
\end{tabular}

TABELA 20- MÉDIA, MEDIANA E DESVIO-PADRÃO DO LAJIR POR QUANTIDADE DE UEN

Para o múltiplo do LAJIR, a situação se modifica no que tange a média e quantidade de empresas. O grupo de empresas com 3 UEN é o que apresenta a menor média e mediana embora seja uma das maiores composições na amostra. Já o grupo com 5 ou mais UEN é o que apresenta o menor número de empresas e uma das maiores médias. A melhor rentabilidade média anual por empresa é encontrada no grupo com 1 UEN (US\$ 28 milhões) e a pior rentabilidade média anual por empresa é a que encontra-se no grupo de 3 UEN. O grupo com 5 ou mais UEN também apresenta uma boa rentabilidade média anual por empresa comparando-se com os demais grupos (US\$ 27 milhões).

A rentabilidade média anual por empresa é calculada através do valor médio total do LAJIR para determinado grupo divido pelo número de empresas que compõem aquele grupo. Assim, para se obter os US\$28 milhões do grupo com 1 UEN, dividiu-se US\$2.721 milhões por 96 empresas.

A seguir, apresenta-se a evolução gráfica dos UEN para o múltiplo de LAJIR: 


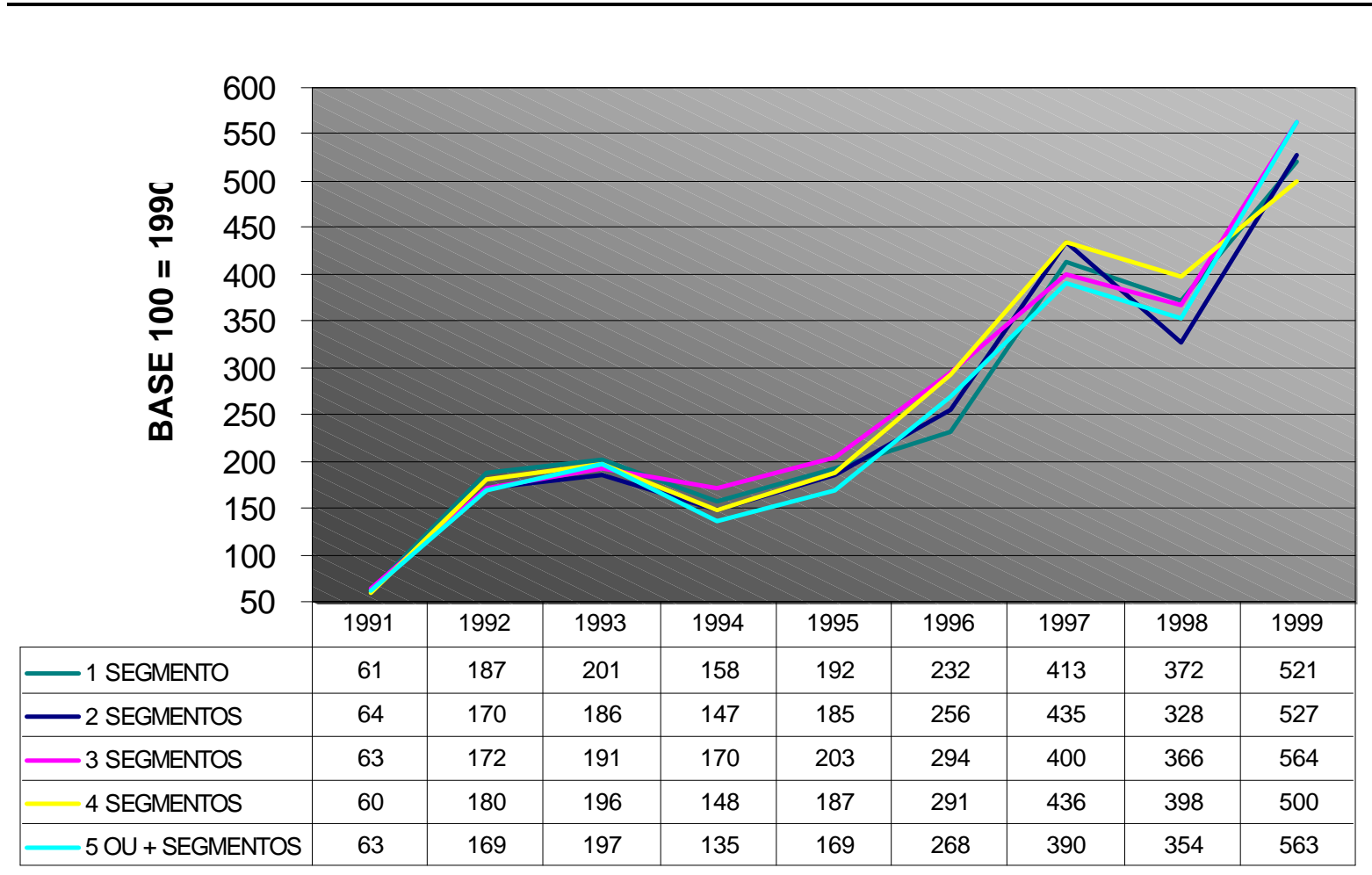

\section{GRÁFICO 8 - EVOLUÇÃO DO LAJIR POR QUANTIDADE DE UEN}

A análise gráfica revela que no ano de 1991, todos os grupos de empresas apresentaram queda no crescimento do LAJIR em comparação ao ano anterior. Depois deste ano, todos os anos apresentaram crescimentos acumulados. O grupo de empresas que mais cresceu no período estudado foi o grupo que possuía 3 UEN e que foi acompanhado pelo grupo de empresas que possuíam 5 ou mais UEN em 1999. Novamente, o ano de 1998 apresentou-se como um período de retração em relação ao ano anterior mas que foi compensado em todos os grupos no ano de 1999. Todos os grupos cresceram mais de 4 vezes no período de estudo.

A evolução do LAJIR por quantidade de UEN mostrou-se mais uniforme que a evolução por tipo de segmento. Isto pode-se verificar através da comparação de ambos os gráficos. Com exceção do ano de 1991 que houve retração para todos os grupos, nos anos seguintes, nenhum grupo classificado por quantidade de UEN apresentou-se menor que o 
ano-base enquanto que pela classificação do tipo de segmento houve retrações até o ano de 1994.

\section{IV.4. TESTES DE HIPÓTESES}

O objetivo dos testes de hipóteses para médias é avaliar afirmações feitas a respeito de médias populacionais. Os diversos testes exigem dados quantitativos, isto é, dados contínuos ou discretos.

Há basicamente três tipos de afirmação que se podem fazer acerca de médias populacionais, e cada tipo requer um tipo diferente de avaliação. Uma afirmação pode dizer respeito à média de uma única população: a avaliação envolve então um teste de uma amostra. Ou pode-se afirmar que as médias de duas populações são iguais; tem-se então um teste de duas amostras. Finalmente, pode-se afirmar que as médias de mais de duas populações são todas iguais, o que envolve um teste de $k$ amostras. Esta última situação é a análise de variância.

A análise de variância é uma técnica que pode ser usada para determinar se a média de duas ou mais populações são iguais. O teste se baseia numa amostra extraída de cada população. Ela pode ser utilizada para determinar se as médias amostrais sugerem diferenças efetivas entre as amostras, ou se tais diferenças decorrem apenas da variabilidade amostral. Se o teste estatístico (análise de variância) levar a aceitar a hipótese de nulidade, conclui-se que as diferenças observadas entre as médias amostrais são devidas a variações aleatórias na amostra. No caso de rejeição da hipótese de nulidade, conclui-se que as diferenças entre as médias amostrais são demasiadamente grandes para serem devidas à chance.

Um dos testes de hipóteses a serem realizados neste estudo diz respeito à média da quantidade de UEN por empresa por ano. Caso esta média apresente crescimento durante o período estudo, pode-se 
concluir que há diversificação das empresas. Porém, o teste de hipóteses é utilizado quando se tem médias amostrais de populações com distribuição normal. Neste estudo, trabalha-se com toda a população e não com amostras. Na verdade, as amostras representam a população. Obviamente que está população é caracterizada pelas várias restrições feitas tais como pertencerem ao banco de dados CIS, faturamento superior a US\$20 milhões por ano, não possuir UEN na indústria de segmentos financeiros entre outros. As empresas que satisfizeram as exigências colocadas foram incluídas na amostra. Portanto, pode-se afirmar que se este trabalho contempla toda a população e que, por conseguinte, a amostra é a própria população.

Sendo assim, os testes de hipóteses que serão realizados na realidade serão análises gráficas das evoluções das médias populacionais.

\section{IV.4.1. NÚMERO MÉDIO DE UEN}

O objetivo deste estudo refere-se a diversificação das empresas do setor de telecomunicações porém, para enriquecer as análises, criou-se categorias por segmentos identificados dentro do subgrupo 3661 do SIC. Através desta classificação, avaliou-se os múltiplos por segmento. Para verificar o crescimento ou não da quantidade de UEN por empresas durante os anos de 1990 a 1999, optou-se também por mostrar a evolução por segmentos muito embora o foco principal seja a média das empresas pertencentes à amostra.

A seguir apresenta-se a média, mediana e desvio-padrão por tipo de segmento referente ao período de estudo assim como das empresas como um todo: 


\begin{tabular}{l|c|c|c}
\hline Segmentos & Média & Mediana & Desvio \\
\hline Telefonia Fixa & 2,26 & 2,24 & 0,55 \\
\hline Telefonia Móvel & 2,25 & 2,25 & 0,54 \\
\hline Infra-estrutura & 2,28 & 2,34 & 0,52 \\
\hline $\begin{array}{l}\text { Comunicação de } \\
\text { Dados }\end{array}$ & 2,20 & 2,10 & 0,58 \\
\cline { 2 - 4 } Transmissão & 2,24 & 2,29 & 0,60 \\
\hline Outros & 2,26 & 2,27 & 0,57 \\
\hline TOTAL & $\mathbf{2 , 2 5}$ & $\mathbf{2 , 2 7}$ & $\mathbf{0 , 5 5}$ \\
\hline
\end{tabular}

TABELA 21 - MÉDIA, MEDIANA E DESVIO-PADRÃO DO QUANTIDADE DE UEN

Muito embora todos os segmentos apresentem-se próximos a média total do grupo $(2,25)$, pode-se notar que o segmento Comunicação de Dados é o que apresenta a menor média e mediana enquanto que 0 segmento de Infra-estrutura apresenta a maior média e mediana. Através do desvio-padrão do segmento Transmissão pode-se adiantar que este segmento é o que deve apresentar maior variação durante os anos do estudo.

A análise do resultado da média total $(2,25)$ com a mediana total $(2,27)$ permite sugerir que uma aceleração da evolução do número médio de UEN a partir do meio do período estudado. Ou seja, em torno dos anos de 1994/1995, o crescimento pode ter aumentado (a curva do gráfico deve ter uma característica exponencial a partir deste período).

Como as médias são muito próximas às medianas, optou-se por analisar os dados dos números médios de UEN através da média aritmética e não da mediana. Estas análises podem ser confrontadas com o gráfico apresentado a seguir: 


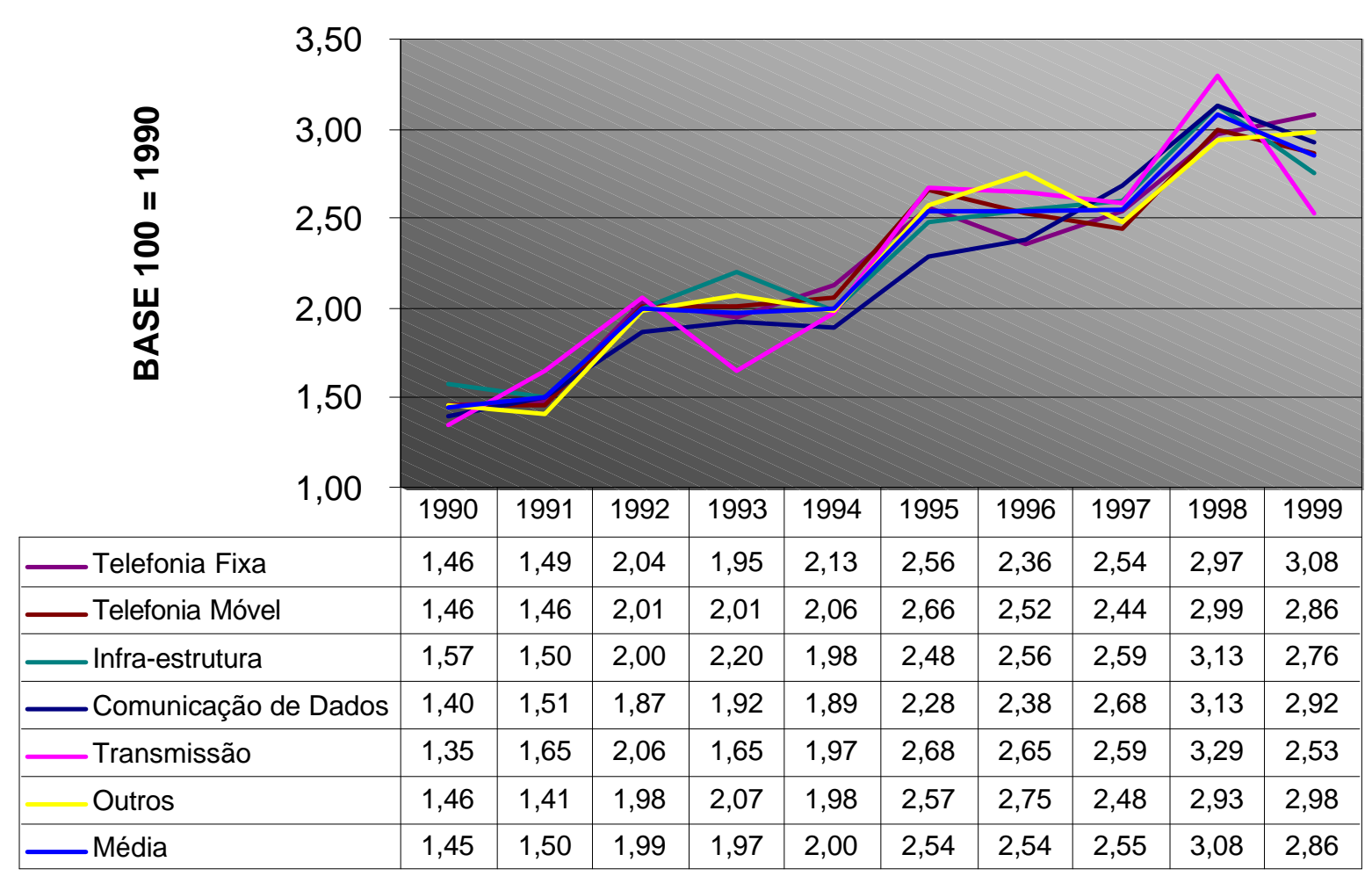

GRÁFICO 9 - EVOLUÇÃO DO NÚMERO MÉDIO DE UEN

Entre 1990 e 1999, o número médio de UEN por empresa praticamente duplicou, ou seja, saiu de 1,45 e chegou a 2,86. Com exceção de 1998, houve um crescimento no número médio de UEN por empresa durante todo o período. O segmento de Telefonia Fixa foi o que mais cresceu, atingindo 3,08 UEN por empresa em 1.999. O setor de Transmissão chegou a ter o maior número médio de UEN em $1998(3,29)$ mas foi reduzido no ano seguinte. Aliás, neste mesmo ano três segmentos chegaram a ter média superior a 3 UEN por empresa, conduzindo a média para o nível superior a este patamar também.

Conforme havia sido adiantado pelo desvio-padrão da média dos segmentos, a quantidade de UEN cresce de forma contida até o ano de 1994 e a partir deste ano mostra um crescimento mais rápido que os anos anteriores. Graficamente é possível obter esta conclusão. Numericamente, basta verificar na linha da média que para haver um 
acréscimo de 0,5 na média, foram necessários quase 4 anos enquanto que após atingir a barreira das 2 UEN, no ano seguinte o crescimento de 0,5 na média já foi alcançado. Esta mesma velocidade de crescimento ocorreu no ano de 1998. Portanto, pode-se dizer que houve uma concentração de fusões e aquisições durante este período, o que é condizente com a fundamentação teórica que discute 0 recente processo para este mercado.

Porém, é contrário à constatação de COMMENT e JARRELL (1995), discutida na Fundamentação Teórica, que encontrou uma pequena tendência em direção à busca da especialização pelas empresas norteamericanas durante a década de 80 . Em 1988, 55.7\% das empresas estudadas tinham apenas uma unidade de negócio comparado com $38,1 \%$ em 1979. Esta constatação se refere a diversos tipos de empresa.

\section{IV.4.2. CARACTERIZAÇÃO DO SUBGRUPO DE DIVERSIFICAÇÃO}

Após verificar que as empresas pertencentes à amostra deste estudo apresentaram um crescimento no número médio de UEN por empresa entre os anos de 1990 e 1999, concluiu-se que as empresas estão realmente diversificando.

Neste seção o objetivo é avaliar se a diversificação está ocorrendo dentro do setor de telecomunicações (subgrupo 3661 do SIC) ou fora deste subgrupo. Para tanto, adotou-se os anos de 1990 e 1999 como pontos de comparação. Tanto para o primeiro como para o último ano do estudo observou-se quais eram as classificações SIC de cada UEN independente da empresa a que pertenciam (identificadas pelo parental code). Montou-se então a seguinte tabela demonstrando a participação percentual de cada subgrupo baseando-se na quantidade de UEN: 


\begin{tabular}{l|l|r|r|r}
\hline SIC & Descrição & 1990 & 1999 & \multicolumn{1}{c}{$\Delta$} \\
\hline 3571 & Eletronic Computers & $3 \%$ & $5 \%$ & $2 \%$ \\
\hline 3661 & Telephone and Telegraphs Apparatus & $90 \%$ & $78 \%$ & $-12 \%$ \\
\hline 3663 & Radio and TV Broadcasting & $0 \%$ & $4 \%$ & $4 \%$ \\
\hline 3669 & Communications Equipment & $1 \%$ & $1 \%$ & $0 \%$ \\
\hline 5734 & Computer Software Storage & $3 \%$ & $7 \%$ & $4 \%$ \\
\hline & Outros & $3 \%$ & $5 \%$ & $2 \%$ \\
\hline
\end{tabular}

TABELA 22 - EVOLUÇÃO PERCENTUAL DOS SUBGRUPOS SIC DENTRO DA AMOSTRA DE 476 EMPRESAS

Em linhas gerais o subgrupo 3571 representa empresas que produzem computadores (hardware); o subgrupo 3663 representa empresas que produzem conteúdo a ser distribuído através da mídia, principalmente rádio e televisão; o subgrupo 3669 representa empresas que produzem aparelhos telefônicos (móveis e fixos); o subgrupo 5734 representa as empresas que produzem e comercializam programas de computadores (software); o subgrupo outros representa todos os demais segmentos que não se encaixam nos anteriores.

Pode-se verificar que tanto em 1990 como em 1999 o subgrupo 3661 permaneceu majoritário porém com uma redução na participação percentual. Em 1990 haviam 709 UEN distribuídas dentro das 476 empresas enquanto que em 1999 este número saltou para 1.405 UEN distribuídas pela mesma quantidade de empresa.

A evidência da diversificação em outros segmentos encontra-se na diminuição da participação do subgrupo 3661 e conseqüente aumento nos demais, com destaque para os subgrupos de computadores (hardware e software) como nas empresas de conteúdo de mídia. 
Esta constatação encontra-se em acordo com o que preconiza a Fundamentação Teórica, que discute a fusão das atividades de telecomunicações, computadores e mídia. Muito embora a participação ainda seja pequena dentro do subgrupo 3661, este movimento encontrase no seu início conforme também foi discutido na Fundamentação Teórica.

A mesma tabela é apresentada a seguir porém com valores absolutos:

\begin{tabular}{c|l|r|r|r}
\hline SIC & Descrição & 1990 & 1999 & $\Delta$ \\
\hline 3571 & Eletronic Computers & 21 & 70 & 49 \\
\hline 3661 & Telephone and Telegraphs Apparatus & 638 & 1096 & 458 \\
\hline 3663 & Radio and TV Broadcasting & 0 & 56 & 56 \\
\hline 3669 & Communications Equipment & 7 & 14 & 7 \\
\hline 5734 & Computer Software Storage & 21 & 98 & 77 \\
\hline & Outros & 21 & 70 & 49 \\
\hline
\end{tabular}

TABELA 23 - EVOLUÇÃO EM VALORES ABSOLUTOS DOS SUBGRUPOS SIC DENTRO DA AMOSTRA DE 476 EMPRESAS

O crescimento do subgrupo 3661 indica que as empresas mantiveram o foco da diversificação em empresa relacionadas. Ou seja, as empresas identificadas dentro do segmento Telefonia Fixa, Telefonia Móvel, Infraestrutura, Comunicação de Dados e Transmissão se diversificaram entre si. Pode-se afirmar que houve a diversificação entre os segmentos pois caso contrário, não haveria crescimento do número médio de UEN.

As evidências empíricas são congruentes com a discussão teórica que precedeu este capítulo.

\section{IV.4.3. VALOR MÉDIO DOS MÚLTIPLOS ANO A ANO}

Após realizar a análise dos múltiplos por segmentos, apresenta-se agora a análise com os valores totais da amostra. O objetivo desta seção é 
mostrar a evolução dos múltiplos durante o período de estudo comparando-os entre si.

A evolução de alguns indicadores pode ser avaliada durante o período de 1990 a 1999, permitindo algumas análise relevantes para verificar os resultados alcançados com o aumento do número médio de UEN por empresa. Dado que aumentou-se de 709 UEN para 1.405 em 10 anos, intuitivamente espera-se verificar o aumento nos ativos e vendas em valores absolutos. Já a verificação de aumento no LAJIR não se pode afirmar nada pois o aumento de UEN pode não conduzir ao aumento do LAJIR.

A seguir, apresenta-se o gráfico com a evolução anual dos múltiplos em valores totais para as 476 empresas:

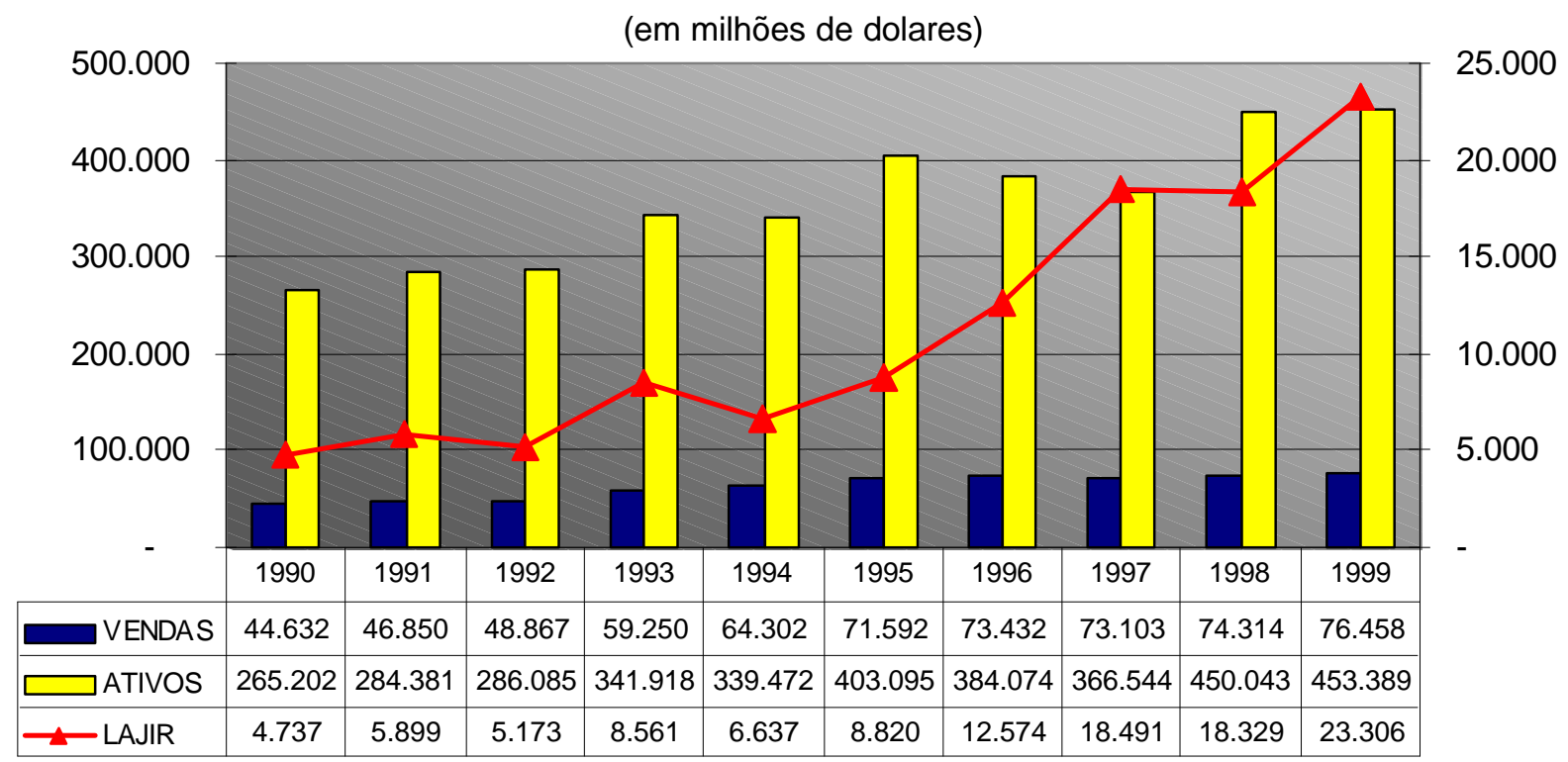

GRÁFICO 10 - EVOLUÇÃO ANUAL DOS MÚLTIPLOS EM VALORES TOTAIS

Observa-se que todos os múltiplos cresceram durante o período estudado. Porém, tanto o múltiplo de Vendas como de Ativos não duplicou neste período, muito embora a quantidade de UEN tenha duplicado. Já o LAJIR, apresentou um crescimento de quase 5 vezes em relação ao seu valor original. Em 1990, estas 476 empresas geram em média $1,80 \%$ de LAJIR sobre o total de Ativos e 10,6\% em relação 
às Vendas. Já em 1999, o LAJIR sobre os Ativos passou para 5,1\% e o $30,5 \%$ sobre as Vendas. Pela tabela pertencente ao gráfico, pode-se verificar que estes índices apresentaram saltos a partir de 1996 quando as vendas permaneceram praticamente estáveis e o LAJIR praticamente dobrou. Este ganho de lucratividade pode estar relacionada com 0 crescimento da quantidade de UEN das empresas. A diversificação (que ocorreu na sua maioria em empresas dentro do mesmo subgrupo conforme verificou-se anteriormente) produziu benefícios para as empresas estudadas no que tange a estes indicadores.

Apesar de se poder verificar sinais positivos com a diversificação, neste ponto não se pode afirmar nada com relação ao efeito da diversificação sobre o valor da empresas pois as empresas podem ter se valorizado mas não no mesmo ritmo que seriam se estivessem sob administração independente. As afirmações só poderão ocorrer após o teste do modelo de BERGER e OFEK.

\section{IV.5. APLICAÇÃO DOS MÚLTIPLOS}

Para examinar se a diversificação aumentou ou diminuiu o valor das empresas, mediu-se a diferença percentual entre o valor total da empresa e a soma dos valores dos suas UEN se eles fossem conduzidos independentes (valores imputados). Calculou-se o valor imputado para cada UEN através da multiplicação da razão da mediana do capital total de empresas com uma única UEN por um dos três itens contábeis (ativos, vendas ou lucro) pela nível da UEN do item contábil.

O banco de dados utilizados na aplicação do modelo de BERGER e OFEK pode ser representada pela figura a seguir: 


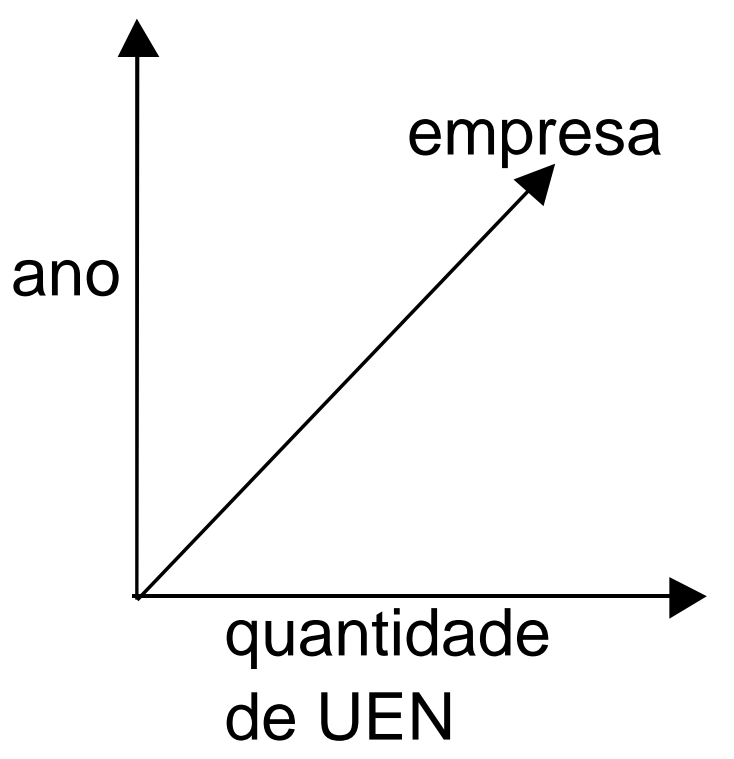

FIGURA 1- MODELAGEM DO BANCO DE DADOS

A variação no eixo "quantidade de UEN" é de 2 até 5 ou mais UEN; já para o eixo da "empresa", a variação foi do número de empresas com mais de uma UEN. No eixo "ano", a variação foi de 1990 a 1999.

Como a verificação da variação do valor é das empresas multisegmentos (ou seja, aquelas que têm mais de uma UEN), a aplicação do modelo contemplou apenas estas empresas. Como citado anteriormente, da amostra de 476 empresas, 96 empresas possuem 1 UEN e 380 empresas possuem mais de 1 UEN. Sendo assim, a amostra utilizada no modelo foi de 380 empresas. Para facilitar o manuseio do banco de dados, atribuiu-se a cada empresa multisegmento um número seqüencial que variou de 1 a 380. Logo, o eixo "empresas" variou de 1 a 380.

De acordo com a aplicação do modelo e observando a figura de modelagem do banco de dados, pode-se constatar que a verificação da variação da empresa se deu em duas partes: primeiramente, calculou-se o valor das empresas multisegmentos como se fossem empresas de uma única UEN ano a ano. Em seguida, calculou-se a mediana dos valores imputados através do modelo de BERGER e OFEK. 
Os testes foram conduzidos separadamente para cada um dos três múltiplos: Vendas, LAJIR e Ativos. A seguir, são apresentados os resultados para cada um deles e, em seguida, a comparação do resultado dos três.

\section{IV.5.1. VENDAS}

O valor mediano das empresas multisegmentos obtido entre os anos de 1990 e 1999 foi de US\$ 444 milhões. Este valor foi utilizado como referência para se comparar aos três múltiplos.

No caso do múltiplo de Vendas, obteve-se através do modelo de BERGER e OFEK o valor mediano de US\$ 416 milhões. Os resultados são apresentados a seguir:

\begin{tabular}{l|c}
\hline (em milhões US\$) & Mediana \\
\hline Valor da Empresa V & 444 \\
\hline Valor Imputado I(V) & 416 \\
\hline
\end{tabular}

TABELA 24 - VALOR IMPUTADO - MÚLTIPLO VENDAS

Através destes números, calculou-se a variação de valor dada pela Equação $2 \mathrm{EXVAL}=\ln (\mathrm{V} / \mathrm{I}(\mathrm{V}))$. O logaritmo natural resultante da divisão entre o valor da empresa $V$ e o valor imputado I(V) foi de 0,064. Ou seja, o fato destas empresas manterem-se diversificadas produziu um ganho de valor em torno de 6,4\% durante os anos de 1990 e 1999 se comparado ao valor de empresas com uma única UEN (nãodiversificadas). 


\section{IV.5.2. ATIVOS}

O Valor da Empresa $V$ utilizada para verificar a variação de valor através do múltiplo de Ativo é o mesmo utilizado no múltiplo de Vendas, ou seja, US\$ 444 milhões.

Para o múltiplo de Ativos, obteve-se através do modelo de BERGER e OFEK o valor mediano de US\$ 424 milhões. Os resultados são apresentados a seguir:

\begin{tabular}{l|c}
\hline (em milhões US\$) & Mediana \\
\hline Valor da Empresa V & 444 \\
\hline Valor Imputado I(V) & 424 \\
\hline
\end{tabular}

\section{TABELA 25 - VALOR IMPUTADO - MÚLTIPLO ATIVOS}

Através destes números, calculou-se a variação de valor dada pela Equação 2 EXVAL = $\ln (\mathrm{V} / \mathrm{I}(\mathrm{V}))$. O logaritmo natural resultante da divisão entre o valor da empresa $\mathrm{V}$ e o valor imputado I(V) foi de 0,045 . Como o valor obtido também é positivo, conclui-se que o fato destas empresas manterem-se diversificadas produziu um ganho de valor em torno de 4,5\% durante os anos de 1990 e 1999.

\section{IV.5.3. LAJIR}

O Valor da Empresa $V$ utilizada para verificar a variação de valor através do múltiplo do LAJIR é o mesmo utilizado no múltiplo de Vendas, ou seja, US\$ 444 milhões.

Para o múltiplo de Ativos, obteve-se através do modelo de BERGER e OFEK o valor mediano de US\$ 443 milhões. Os resultados são apresentados a seguir: 


\begin{tabular}{l|c}
\hline (em milhões US\$) & Mediana \\
\hline Valor da Empresa V & 444 \\
\hline Valor Imputado I(V) & 443 \\
\hline
\end{tabular}

TABELA 26 - VALOR IMPUTADO - MÚLTIPLO LAJIR

Através destes números, calculou-se a variação de valor dada pela Equação $2 \mathrm{EXVAL}=\ln (\mathrm{V} / \mathrm{I}(\mathrm{V}))$. O logaritmo natural resultante da divisão entre o valor da empresa $V$ e o valor imputado I(V) foi de 0,002. Como o valor obtido também é positivo, conclui-se que o fato destas empresas manterem-se diversificadas produziu um ganho de valor em torno de 0,2\% durante os anos de 1990 e 1999. Dos três múltiplos, este é o que apresentou o menor valor mas todos demonstrando que o fato das empresas serem diversificadas (com 2 ou mais UEN), há um ganho de valor de acordo com a metodologia desenvolvida por BERGER e OFEK.

\section{IV.5.4. COMPARAÇÃO ENTRE OS MÚLTIPLOS}

A análise dos três múltiplos mostrou-se que houve um ganho de valor para as empresas que se diversificaram que variou entre $0,2 \%$ e $6,4 \%$. A tabela a seguir apresenta o valor mediano real das empresas multisegmentos comparando-o com os valores obtidos através da aplicação do modelo de BERGER e OFEK. A última linha da tabela apresenta os resultados obtidos através da segunda equação do modelo. Nesta linha pode-se observar as variações positivas de valor:

\begin{tabular}{|c|c|c|c|}
\hline (em milhões US\$) & Vendas & Ativos & LAJIR \\
\hline Valor da Empresa V & 444 & 444 & 444 \\
\hline Valor Imputado I(V) & 416 & 424 & 443 \\
\hline $\begin{array}{l}\text { Variação de } \\
\text { EXVAL }\end{array}$ & $6,4 \%$ & $4,5 \%$ & $0,2 \%$ \\
\hline
\end{tabular}

TABELA 27 - COMPARAÇÃO DO VALOR DA EMPRESA E DO VALOR IMPUTADO 
Contrariamente ao estudo original de BERGER e OFEK onde as empresas apresentaram perda de valor, as empresas aqui estudadas apresentaram um efeito contrário, ou seja, de ganho de valor. Diante desta situação pode-se concluir que há empresas que perderam mais valor que a média para compensar o efeito de ganho destas empresa aqui estudadas.

Calculou-se também a ganho médio em dólares devido a diversificação como a diferença média entre os valores imputados e os valores reais. Utilizando-se do múltiplo de ativos, o ganho médio em dólar por firma durante o período estudado foi de US\$20 milhões, implicando num ganho total em valores para 380 empresas diversificadas da amostra em torno de US\$ 7,6 bilhões.

\section{IV.5.5. VERIFICAÇÃO DA TEORIA}

LEWELLEN (1971) relata em seu estudo a predominância da preocupação naquela época dos pesquisadores em especificar as circunstâncias que pareciam ser razoáveis para que o resultado da fusão entre empresas excedesse o valor das empresas separadamente. Os elementos identificados até então como sendo responsáveis pelo aumento do valor das empresas envolvidas na fusão foram classificados como operacionais e financeiros. Os elementos operacionais eram a oportunidade de economias de escala, fortalecimento da posição competitiva de vendas através do aumento do poder de monopólio ou o apelo de um portfolio de produtos mais variado, complementação da atividade de pesquisa e desenvolvimento e eficiência administrativa dada a deficiência de recursos. Alguns estudos defendiam que se ao menos um destes fatores ocorressem, aumentar-se-ia a lucratividade das empresas e, conseqüentemente, o valor da nova empresa resultante do processo. Uma outra corrente de pesquisadores era cética 
quanto a viabilidade de se obter os resultados apontados. Embora não houvesse um consenso empírico sobre os resultados da fusão, havia o consenso de que as vantagens operacionais citadas seriam mais prováveis de ocorrerem em empresas com atividades similares. Este estudo não tem como objetivo verificar quais os motivos que levaram as empresas à diversificação porém, sugere que se estude quais seriam estes motivos. Intuitivamente e, conforme abordado na Introdução deste trabalho, parece que a diversificação ocorreu devido aos motivos operacionais, destacadamente o fator "apelo de um portfolio de produtos mais variado".

Os dois principais motivos financeiros apontados como estimuladores da formação dos grandes conglomerados da década de 60 eram diminuir a variação dos ganhos através da diversificação do portfolio e a possibilidade de aumentar o endividamento através da empresa adquirida que estava pouco alavancada. O ambiente de diversificação que se estava formando com os conglomerados permitiu que os estudos realizados por MARKOWITZ (1959) sobre a fronteira eficiente fossem então utilizados. Porém, a hipótese de que a formação dos conglomerados visava a diminuição da variação da volatilidade dos ganhos dos acionistas era fraca pois num mercado de capitais eficiente como o analisado por SHARPE (1964) e LINTNER (1965), os investidores poderiam diversificar as suas próprias carteiras de ativos através da compra de ações das empresas com correlação de ganhos negativa. Portanto, a justificativa das fusões através da realização de um procedimento interno, a diversificação, e que poderia ser realizado externamente por investidores, a compra de ações, tornou-se insustentável. Para o escopo deste estudo, o motivo financeiro relacionado a diminuição da variação dos ganhos é pouco provável pois 
a diversificação ocorreu através de UEN que atuam no mesmo setor da economia, ou seja, o mercado de telecomunicações.

O segundo motivo financeiro que poderia justificar a fusão era a capacidade de endividamento da empresa objeto da aquisição que estava sendo pouco utilizada. A hipótese era de que com a fusão ou aquisição, a nova empresa poderia ter uma maior alavancagem que as empresas separadas utilizando-se da capacidade de endividamento ociosa e, assim, obter um maior valor de mercado. Porém, segundo os estudos desenvolvidos por MODIGLIANI e MILLER (1958 e 1963), na ausência de impostos, não há aumento no preço das ações e, conseqüentemente, no preço da nova empresa, devido a variação da estrutura de capital. Este motivo encontra respaldo inicialmente no índice de alavancagem ajustada da indústria (valor contábil dos empréstimos sobre o total de ativos) apresentado na Tabela 13 que é de 2,9\% maior que as empresas focadas em uma única UEN. Porém, não se pode afirmar que este foi o motivo da diversificação. Adicionalmente, há outra série de estudos que levantavam dúvidas sobre a real possibilidade de alcançar estas vantagens e que foram apresentados no capítulo II.

Estudos mais recentes conduzidos por COMMENT e JARREL (1995) constatam que os executivos estão mais dispostos a sustentarem a concentração no negócio principal da empresa, core business, restringindo as estratégias de crescimento via fusões e retornando a especialização através da reestruturação e desinvestimentos. O resultado do estudo aponta para um retorno a especialização iniciado timidamente no começo da década de 80.

Esta nova ênfase na especialização é consistente com JENSEN (1988) que argumenta que os programas de diversificação das empresas exemplificam a teoria de que os executivos com possibilidade de 
aumentar a alavancagem da empresa através de endividamento e disponibilidade de caixa são mais susceptíveis a investirem em projetos que destroem valor do acionista. Ambos os estudos são contrários à constatação feita neste estudo para o mercado de telecomunicações durante os anos de 1990 e 1999.

BERGER e OFEK (1995) citam vários custos criados com a diversificação levantados em trabalhos anteriores tais como oportunidades de investimentos ruins, disponibilidade de caixa e de endividamento não utilizados, investimento em projetos com valor presente líquido negativo, manutenção de linhas de produção nãorentáveis e assimetria de informação. Acrescentam que alguns trabalhos não distinguem entre diversificação relacionada e não-relacionada. Aqueles que distinguem, concluem que o efeito da diversificação é mais positivo para empresas com linhas de produtos relacionadas do que aquelas com linhas não-relacionadas.

Para BREALEY e MYERS (1997) há muitas razões plausíveis para que duas empresas desejem fundir-se porém "... o que necessitamos é de uma hipótese geral que explique as fusões". Eles também defendem a posição de Segall levantada há mais de 30 anos e citada no capítulo I. Este estudo não buscou esta hipótese mas o efeito no valor das empresas diversificadas em relação às empresas com uma única UEN. Contudo, pode-se notar que os motivos pelos quais as empresas de telecomunicações diversificaram (aumento no número médio de UEN) não são fáceis de serem identificados; há muita divergência sobre os mesmos.

O método utilizado apresentou resultados que variaram entre $0,2 \%$ e $6,4 \%$, sendo que o múltiplo de LAJIR conduziu à menor variação. Se analisado apenas este múltiplo, pode-se entender que a diversificação é indiferente para o valor da empresa de acordo com o método de 
BERGER e OFEK. Os dados da Tabela 14 demonstram que 9\% das UEN diversificados apresentam fluxo de caixa negativo contra $8,2 \%$ das empresas com uma única UEN. A maior presença do fluxo de caixa negativo entre as UEN de empresas diversificadas é consistente com a afirmativa de que empresas diversificadas mantêm divisões com desempenhos abaixo do que elas teriam se fossem conduzidas isoladamente. Ou seja, a pequena valorização pode ser devido a presença de fluxo de caixa negativo.

Se a verificação do valor da empresa fosse através do modelo econômico discutido no item II.11.1, que é o Fluxo de Caixa Descontado, estas empresas que apresentaram fluxo de caixa negativo teriam o seu valor reduzido para qualquer que fosse a taxa de desconto. Este método é freqüentemente utilizado pois é capaz de capturar todos os elementos que afetam o valor da empresa de uma maneira compreensiva.

Os resultados obtidos com relação ao crescimento do número médio de UEN e de ganho de valor com a diversificação fazem com que a hipótese $\mathrm{H}_{0}$ seja rejeitada pois ela diz que:

$\mathrm{H}_{0}$ : A onda de fusões e aquisições que o mercado de telecomunicações está enfrentando não está agregando valor ao acionista através da diversificação.

A primeira parte da afirmativa que se refere a onda de fusões e aquisições tem vários embasamentos teóricos apresentados neste estudo. Para citar os dois mais relevantes, tem-se o crescimento das operações de fusões e aquisições conforme apresentado nas Tabelas 6 e 7 e Gráficos 1 e 2 e o crescimento do número médio de UEN por empresa conforme apresentado no Gráfico 9.

A segunda parte que afirma que este processo em discussão não está agregando valor é negado pelos resultados obtidos através das 
Equações 1 e 2 que indicam ganhos de valor para as empresas diversificadas (com mais de uma UEN).

Dado que se rejeitou a hipótese nula, aceitou-se a seguinte hipótese:

$\mathrm{H}_{1}$ : $\mathrm{O}$ processo de fusões e aquisições no mercado de telecomunicações está agregando valor ao acionista através da diversificação.

Esta hipótese é confirmada pelo ganho de valor entre 0,2\% e 6,4\% conforme o modelo utilizado de BERGER e OFEK. 
Capítulo V:

CONSIDERAÇÕESFINAIS 


\section{CONSIDERAÇÕES FINAIS}

Estudou-se os efeitos da diversificação no valor das empresa através da estimativa das UEN diversificadas caso eles fossem operadas separadamente. Fazendo isto, conclui-se que a diversificação aumentou o valor. Estimou-se que este ganho de valor ficou entre 0,2 e 6,4\% durante o período da pesquisa, ocorrendo entre empresas de vários tamanhos. Em valores absolutos, este ganho representou aproximadamente US\$14 bilhões. Com a obtenção destes resultados, chegou-se à resposta proposta no item 1.3 - Definição da Situação Problema:

\section{Qual foi o efeito da diversificação no valor das empresas do setor de telecomunicações de acordo com a metodologia desenvolvida por BERGER e OFEK?}

A discussão realizada no capítulo II - Fundamentação Teórica discorreu sobre os motivos tratados na literatura para alocação de recursos em diferentes tipos de investimentos e de diferentes formas passando pela discussão da diversificação como redução de risco. No desenvolvimento deste estudo verificou-se apenas as diferentes formas de alocação de recursos (tipo de setor e quantidade de UEN) porém, não verificou se houve efetivamente ganho com a diversificação.

A discussão da evolução da diversificação à especialização ainda no capítulo II mostrou-se dispare da situação das empresas do setor de telecomunicações pois estas estão passando pelo estágio que a grande parte das empresas norte-americanas passou no final da década de 60 e início da década de 70 que foi de aumentar a quantidade de UEN. Assim sendo, levanta-se a hipótese se o movimento em direção a especialização não será o futuro do mercado de telecomunicações, fazendo com que as mesmas optem por alianças estratégias. Por esta 
hipótese, sugere-se que o que está acontecendo hoje com o mercado de telecomunicações, foi o mesmo que ocorreu com as empresas norteamericanas em geral nas décadas de 60 e 70 e que está acontecendo com elas hoje, será o futuro das empresas de telecomunicações que entraram atrasadas no processo pois até o início da década de 90 este mercado era estatizado.

Embora o modelo proposto por BERGER e OFEK tenha vantagens sobre outros métodos (talvez o principal é a não necessidade de se identificar a data da fusão ou aquisição), reconhece-se que outros métodos para medida de valor tais como o Fluxo de Caixa e o EVA ${ }^{\circledR}$ são mais utilizados para medir a riqueza do acionista além do Retorno Total para o acionista que considera os dividendos pagos em dinheiro mais o ganho de capital do acionista.

A identificação da amostra através da quantidade de UEN e da composição da empresa foram peças-chave no desenvolvimento deste trabalho pois se referiam à população em estudo e não à amostra. Afirma-se que se referiram à população pois utilizou-se todas as empresas que atenderam aos requisitos de seleção tais como não possuir UEN no setor financeiro e faturamento maior ou igual a US\$20 milhões por ano. Este foi o motivo do teste de hipótese ter sido realizado de forma simples pois constatou-se a evolução ascendente do número médio de UEN de forma gráfica e estatística e, portanto, o rumo à diversificação.

Dado que o estudo original compreendeu vários setores da indústria norte-americana e que o resultado alcançado foi a perda de valor entre 13 e $15 \%$, pode-se concluir que houve UEN que perderam muito mais com a diversificação do que as empresas do setor de telecomunicações pois estas apresentaram ganho. 
O trabalho original conduzido por BERGER e OFEK prossegue com o estudo sobre as prováveis fontes de ganhos e perdas na diversificação. Eles se concentram nos três itens mais citados na literatura que são: superinvestimentos, subsídios entre unidades de negócio e as vantagens oriundas da alavancagem financeira.

Além de concluírem que o efeito da diversificação conduziu a perda de valor no período estudo para diferentes tamanhos de empresas, eles verificaram o efeito sobre a diversificação em indústrias relacionadas. Eles verificaram que a diversificação reduz o valor da empresa que apresenta baixa rentabilidade operacional em relação a unidades com uma única UEN. A rentabilidade operacional foi medida através da razão LAJIR e vendas e pela razão LAJIR e ativos (ROA).

Também verificaram que o superinvestimento está associado com o baixo valor de empresas diversificadas e que as UEN diversificadas tendem a apresentá-lo mais que as empresas com uma única UEN.

Considerando o ganho de valor para as empresa de telecomunicações, sugere-se como estudos futuros, o desenvolvimento do restante do trabalho conduzido por BERGER e OFEK para identificar as fontes de ganho de valor das empresas diversificadas além de melhor caracterizar quais as características das UEN mais propensas a ganharem valor.

Em síntese, não se tentou levantar qual a hipótese geral que explique as fusões que geraram diversificação nas empresas do mercado de telecomunicações mas sim qual o efeito no valor da empresa. Porém, verificou-se que os resultados alcançados estão em sentido contrário aos estudos já realizados. Este fato pode ser suportado pelo fato das fusões e aquisições no setor de telecomunicações ser um acontecimento recente, oriundo da desregulamentação do setor e sua privatização. Além disto, o crescimento dos diversos tipos de serviços oferecidos através das empresas de telefonia além do tráfego de voz. 


\section{V.1. SUGESTÕES PARA ESTUDOS FUTUROS E LIMITAÇÕES}

Em decorrência dos resultados alcançados, sugere-se desenvolvimento de novas pesquisas com a finalidade de responder perguntas as quais não foram objetos desta dissertação mas que surgiram durante o seu desenvolvimento.

A primeira sugestão é continuar com o modelo proposto de BERGER e OFEK e identificar quais foram as fontes de ganhos de valor para as empresas dado que a diversificação produziu um efeito positivo nas mesmas. Pode-se manter os três principais motivos citados pela literatura. Outra sugestão para estudos futuros é comparar o valor destas mesmas empresas através de diferentes métodos de medida tais como o Fluxo de Caixa Descontado, EVA ${ }^{\circledR}$, Lucro Econômico dentre outros.

Dado que o estudo de BERGER e OFEK demonstra a relação entre o tamanho da empresa e a perda e/ou ganho obtido, sugere-se desenvolver uma pesquisa com este mesmo objetivo para verificar se o ganho de valor das empresas do setor de telecomunicações está relacionado com o seu tamanho.

Este estudo também pode ser utilizado para verificar se o setor de telecomunicações não está repetindo a trajetória das demais empresas norte-americanas que iniciaram o processo de diversificação na década de 60 e o continuaram na década seguinte para então, iniciar um processo inverso na década de 80 . A década de 90 foi a década de diversificação das empresas de telecomunicações medido pelo aumento do número médio de UEN. Possivelmente, este movimento ainda continuará por algum tempo e talvez entre no ciclo do retorno a especialização. Este estudo pode sugerir novas considerações nas suas estratégias para as empresas tais como alianças estratégicas ao invés de fusões. 
Conforme já foi descrito na Metodologia de Pesquisa, este estudo limitase a verificação da variação do valor da empresa de acordo com o modelo de BERGER e OFEK em função da diversificação através do processo de fusão e aquisição. Desconsiderou-se decisões estratégicas de longo prazo que as empresas poderiam vir a assumir no processo de fusão e aquisição. Resumidamente, não se considerou a possibilidade de os acionistas admitirem uma estratégia que venha a trazer perda de valor nos primeiros anos com o objetivo de obter um ganho compensatório no longo prazo.

Outra limitação se refere à população pesquisada. Este estudo não se utilizou de amostras populacionais mas de uma população. Porém, esta população apresenta características bem definidas tais como ser empresas norte-americanas do setor de telecomunicações que se encaixam na classificação como vendors (subgrupo SIC 3661) entre o período de 1990 e 1999 e que tenham apresentado faturamento líquido anual maior ou igual a US\$20 milhões e não apresentem UEN na indústria de serviços financeiros.

Finalizando, entende-se que a seguinte afirmação de SEGALL (1968):

"Não há uma única hipótese que seja simultaneamente plausível e geral e que prometa explicar o atual movimento de fusões. Assim sendo, é correto dizer que não se sabe nada conhecido sobre fusões; não há quaisquer generalizações úteis".

ainda não foi respondida mas que o "atual movimento de fusões" perdura ao menos para o mercado de telecomunicações. 
REFERÊNCIAS BIBLIOGRÁFICAS 
1. Amihud, Y., Lev, B., 1981 "Risk reduction as a managerial motive for conglomerate mergers" Journal of Economics 12, pp. 605-617

2. Berger, P. G., Ofek, E., 1995, "Diversification's effect on firm value" Journal of Financial Economics 37 p. 39-65

3. Boisi, G. T., Essig, S. M., 1994 "Development of the M\&A Market" Cap. 2 In: The Mergers \& Acquisitions Handbook, Rock, M., Rock, R. H., Sikora, M (editors), $2^{\text {nd }}$ Edition, McGraw-Hill, Inc.

4. Brealey, R. A., Myers, S. C. "Princípios de Finanças Empresariais" Editora McGraw-Hill de Portugal, LDA, 5a. edição, 1997

5. Chatterjee, S., Wenerfelt, B., 1991, "The link between resources and type of diversification: Theory and evidence" Strategic Management Journal 12 p. 33-48

6. Chesnais, F., 1990 "Present international patterns of foreign direct investment: underlying causes and some policy implications for Brazil" Texto preparado para o Seminário "The International Standing of Brazil in the 1990s" Campinas, CERI, Instituto de Economia, UNICAMP

7. Comment, R., Jarrel, G. A., 1995, "Corporate focus and stock returns" Journal of Financial Economics 37 p. 67-87

8. Copeland, T. E., Weston, J. F., 1979 "Financial Theory and corporate policy" Addison-Wesley, Reading, MA

9. Copeland, T., Koller, T., Murrin, J., 1990, "Valuation: Measuring and managing the value of companies" John Wiley \& Sons, New York 10. Coutinho, L., Cassiolato, J. E., Silva, A. L. G. (Coords.) 1995 "Telecomunicações, Globalização e Competitividade" Papirus, Campinas SP

11. Csillag, J. M., 1995, "Análise do Valor" 4a. edição, Editora Atlas, São Paulo - SP 
12. Damodaran, A., 1994 "Damodaran on valuation" John Wiley \& Sons, New York

13. Damodaran, A., 1997 "Corporate Finance - Theory and Practice" John Wiley \& Sons, New York

14. Dizard Jr., W., 2000“A Nova Mídia”, 2a. edição, Jorge Zahar Editor 15. Ehrbar, A. 1998, "EVA: the real key to creating wealth" John Wiley \& Sons, New York

16. Freeman, C., Soete, L., 1985 "Information technology and employment: An assessment, Brussels, IBM

17. Gitman, L. J., 1997, "Princípios de Administração Financeira”, 7a. edição, Editora Harbra Ltda, São Paulo - SP

18. Givoly, D., Haynn, C., e D'Souza, J., 1993, "The quality and information content of segment reporting, Working Paper (Northwestern University, Evanston, IL)

19. Godoy, A. S., 1995, Introdução à pesquisa qualitativa e suas possibilidades. Revista de Administração de Empresas, São Paulo, v. 35 n.2, p.57-63, mar/abr.

20. Harbison, J., Pekar, Jr., Peter, 1999 "Smart Alliances: a practical guide to repeatable success" Jossey-Bass Business Publisher

21. Harris, M., Kriebel, C. H., Raviv, A., June 1982, "Asymmetric information, incentives and intrafirm resource allocation" Management Science Vol. 28, no. 6, p. 604-620

22. Jensen, M. C., 1986, "Agency costs of free cash flow, corporate finance, and takeovers" American Economic Review 76 p. 323-329 23. Jensen, M. C., 1988, "Takeovers: Their causes and consequences" Journal of Economic Perspectives 2, pg 21-48 24. John, K., Ofek, E. 1994, "Asset sales and increase in focus" Journal of Financial Economics 37, pp. 105-126 
25. Kassai, J. R., Kassai, S., Santos, Ariovaldo, Assaf Neto, A., 2000 "Retorno de Investimento - Abordagem matemática e contábil do lucro empresarial" Editora Atlas S.A. São Paulo - SP

26. Levy, H., 1991 "Possible explanations of no-synergy mergers and Quantitative Finance and Account 1, pp. 101-127

27. Lewellen, W. G., 1971, "A pure financial rationale for the conglomerate merger" Journal of Finance 26, p. 521-537

28. Liebeskind, J., Opler, T. C., 1993, "The causes of corporate refocusing" Working paper (Southern Methodist University, Dallas, TX)

29. Lindenberg, E. B., e Ross, S. A., 1981, "Tobin's q ratio and industrial organization" Journal of Business 54, p. 1-32

30. Lintner, J. "Security prices, risk, and maximal gains from diversification" Journal of Finance, December 1965, pp. 587-615

31. Lorante, P., Kotlarchuck, E., Singh, H., 1994 "Corporate Acquisitions: A strategic perspective" Cap. 1 In: The Mergers \& Acquisitions Handbook, Rock, M., Rock, R. H., Sikora, M (editors), $2^{\text {nd }}$ Edition, McGraw-Hill, Inc.

32. Mansell, R., Morgan, K., 1990 "Communicating across boundaries: The winding road to broadband networking" In: Perspectives to advanced communications in Europe 1990, vol. II, Brussels, Commission of the European Communities

33. Markowitz, H. M., "Portfolio selection: efficient diversification of investments" New York, Wiley, 1959

34. Marshall, A., 1.890, "Principles of Economics" Macmillan, New York

35. Mattar, F. N., 1994, Pesquisa de Marketing, São Paulo, Atlas, $2^{\text {a. }}$ edição. 
36. Meyer, M., Milgrom, P., Roberts, J. 1992 "Organizational prospects, influence costs, and ownership changes" Journal of Economic \& Management Strategy 1, pp. 9-35

37. Miller, M.H., Modigliani, F., 1961, "Dividend Policy, Growth, and the Valuation of Shares" Journal of Business, 34, 4, pp.411-433

38. Modigliani, F., Miller, M.H. "Corporate income taxes and the cost of capital: a correction" American Economic Review (June 1963), pp. 433-443

39. Modigliani, F., Miller, M.H. "The cost of capital, corporation finance, and the theory of investment" American Economic Review (June 1958), pp. 261-297

40. Mork, R., Shleifer, A. e Vishney, R. W., 1990, "Do managerial objectives drive bad acquisitions" Journal of Finance v. 45, p. 31-48 41. Myers, S. e Majluf, N. S., 1984, "Stock issues and investment policy when firms have information that investors do not have" Journal of Financial Economics 13, pp. 187-222

42. Myers, S., 1977 "The determinants of corporate borrowing" Journal of Financial Economics 5, pp. 147-175

43. Nayyar, P. R., 1993, "Stock market reactions to related diversification moves by service firms seeking benefits from information asymmetry and economies of escope" Strategic Management Journal, vol. 14 p. 569-591

44. Park, R., 1998, “Value engineering: a plan for invention” St. Lucie Press, Boca Raton

45. Peterson, P. P., Peterson, D. P., 2000 "Performance de empresas e medidas de valor adicionado" ABAMEC Nacional

46. Porter, M. E., 1987 "From competitive advantage to corporate strategy" Harvard Business Review 5(3) pp. 43-59 
47. Pyndik, R. S., Rubinfeld, D. L., 1994 "Microeconomia" Makron Books

48. Rempushesk, V., 1997, NUR301 - Nursing Research In: Notas de Aula, turma 11, Rochester, EUA, Universidade de Rochester, 08/12/97

49. Rock, M. L., Rock, R. H., Sikora, M., (Editors) 1994 "The Mergers and Acquisitions Handbook" McGraw-Hill, Inc. $2^{\text {nd }}$ edition

50. Ross, S. A., Westerfiled, R. W., Jaffe, J. F., 1995 "Administração Financeira" Editora Atlas S.A., São Paulo

51. Rumelt, R. P., 1974, "Strategy, structure and economic performance" Division of Research, Harvard Business School, Boston, MA

52. Segall, J., 1968 "Merging for fun and profit" Industrial Management Review 9, pg 17-30

53. Selltiz, C., 1975, Métodos de pesquisa em relações sociais, São

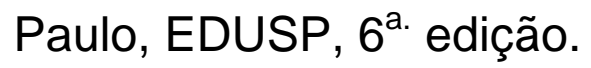

54. Sharpe, W. F., "Capital asset prices: a theory of market equilibrium under conditions of risk" Journal of Finance, September 1964, pp. 425-442

55. Smirlock, M., Gilligan, T., e Marschall, W., 1984, "Tobin's q and the structure-performance relationship" American Economic Review 74, p. $1051-106$

56. Smith, R. G. E., 1971 "Uncertainty, information and investment decisions" The Journal of Finance 26, March, pg. 67-82

57. Stevenson, W. J., 1.986, "Estatística Aplicada à Administração", São Paulo, Editora Harbra Ltda.

58. Stulz, R. M., 1990, "Managerial discretion and optimal financing policies" Journal of Financial Economics 26, p. 3-27 
59. Weston, J. F., 1994 "The payoff in mergers and acquisitions" Cap. 5 In: The Mergers \& Acquisitions Handbook, Rock, M., Rock, R. H., Sikora, M (editors), $2^{\text {nd }}$ Edition, McGraw-Hill, Inc.

60. Weston, J. F., Chung, K. S., Hoag, A. E., 1990 "Mergers, Restructuring, and Corporate Control" Prentice Hall 